\title{
WATER RESOURCES IN
}

BASIN-FILL DEPOSITS IN THE

TULAROSA BASIN, NEW MEXICO

By Brennon R. Orr and Robert G. Myers

U.S. GEOLOGICAL SURVEY

Water-Resources Investigations Report 85-4219

Prepared in cooperation with the

U.S. BUREAU OF RECLAMATION

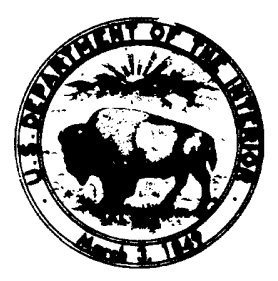

Albuquerque, New Mexico 


\section{UNITED STATES DEPARTMENT OF THE INTERIOR \\ DONALD PAUL HODEL, Secretary}

GEOLOGICAL SURVEY

Dallas L. Peck, Director

For additional information write to:

District Chief

U.S. Geological Survey

Water Resources Division

505 Marquette NW, Room 720

Albuquerque, New Mexico 87102
Copies of this report can be purchased from:

Open-File Services Section Branch of Distribution

U.S. Geological Survey, MS 306 Box 25425, Denver Federal Center Denver, Colorado 80225

(303) 236-7476 


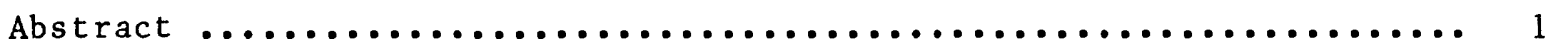

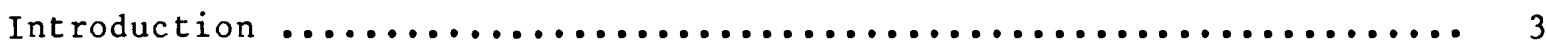

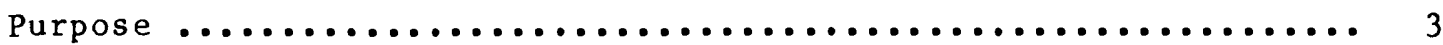

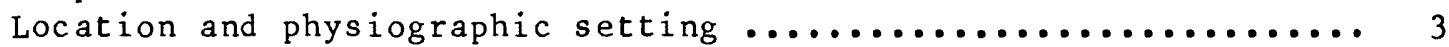

Previous hydrologic studies ............................ 5

Approach ...........................................

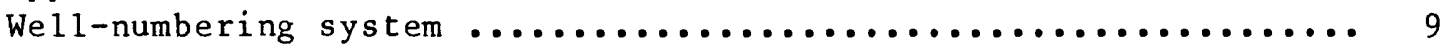

Geohydrologic framework ................................. 10

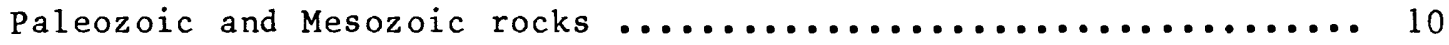

Cenozoic deposits .................................. 10

Stratigraphic relationships of basin-fill hydrologic units from geophysical studies and well data .......... 10 Delineation of basin-fill hydrologic units ............. 11

Distribution of water quality in basin-fill deposits ..................

Fresh and slightly saline water in alluvial fans ................

Eastern side of the Tularosa Basin ................... 17

Three Rivers and Rinconada Creek ................. 17

Grapevine Canyon to La Luz .................... 17

Western side of the Tularosa Basin ................... 45

Rhodes Canyon alluvial fans ................... 45

Ash Canyon alluvial fan ....................... 52

Saline water in central-basin deposits ................. 57

Hydrologic properties of basin-fill deposits .................. 60

Hydrologic properties of alluvial fans ................... 60

Eastern side of the Tularosa Basin .................. 60

Holloman Air Force Base well fields .............. 61

Al amogordo-Tularos a wells ...................... 63

Western side of the Tularosa Basin ................... 64

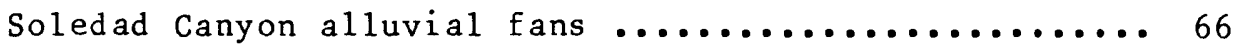

White Sands Missile Range Post Headquarters area ..... 68 


\section{CONTENTS - Concluded}

Hydrologic properties of basin-fill deposits - Con't.

Hydrologic properties of alluvial fans - Con't.

Western side of the Tularosa Basin - Con't.

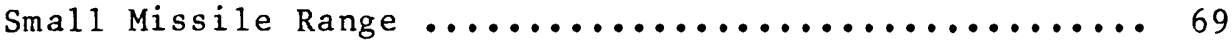

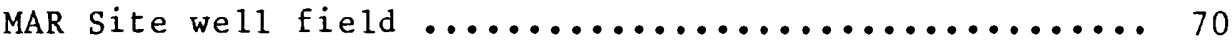

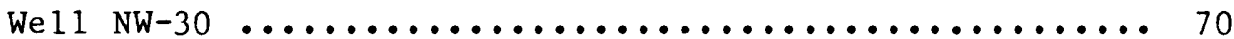

Hydrologic properties of fluvial and eolian deposits in the south-central part of the Tularosa Basin ............... 72

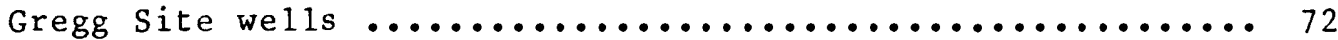

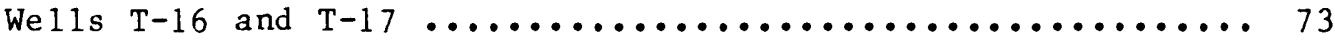

Hydrologic properties of lacustrine deposits in the central

part of the Tularosa Basin .......................... 74

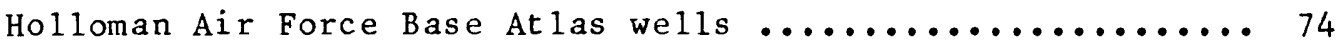

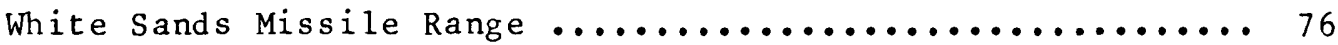

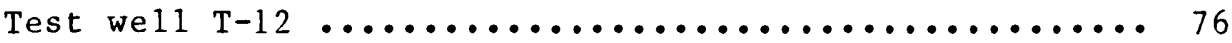

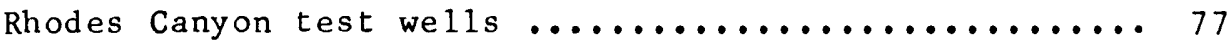

Hydrologic properties of the central-basin gypsum-playa

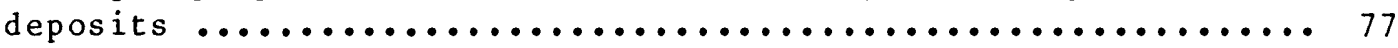

Hydrologic properties of the deep sand unit $(\mathrm{T}-14) \ldots \ldots \ldots \ldots \ldots$

Estimation of water in storage in basin-fill deposits $\ldots \ldots \ldots \ldots \ldots . . .79$

Fresh to slightly saline water $\ldots \ldots \ldots \ldots \ldots \ldots \ldots \ldots \ldots \ldots \ldots \ldots$

Moderately saline water to brine $\ldots \ldots \ldots \ldots \ldots \ldots \ldots \ldots \ldots \ldots \ldots \ldots . \ldots 80 . \ldots$

Summary $\ldots \ldots \ldots \ldots \ldots \ldots \ldots \ldots \ldots \ldots \ldots \ldots \ldots \ldots \ldots \ldots \ldots \ldots \ldots \ldots \ldots \ldots \ldots \ldots \ldots, \ldots \ldots \ldots \ldots$

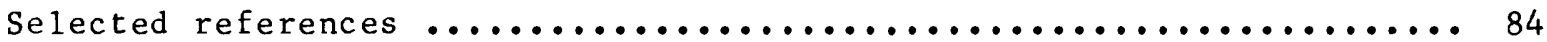

\section{FIGURES}

Figure 1. Map showing location of the study area $\ldots \ldots \ldots \ldots \ldots \ldots \ldots$

2. Diagram showing system of numbering wells in New Mexico ... 9

3. Map showing geology of the southern part of the Tularosa

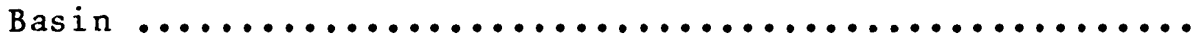




\section{PIGURES - Continued}

Page

Figure 4. Landsat photomap showing basin-fill hydrologic units of the southern part of the Tularosa Basin ............. 14

5. Map showing location of surface electrical-resistivity soundings, Holloman Air Force Base well fields, test wells, and geohydrologic sections, Grapevine Canyon to La Luz ...................................

6. Geohydrologic sections $A-A^{\prime}$ through $K-K^{\prime}$, Grapevine Canyon to La Luz ..................... 20

7. Map showing altitude of the top of consolidated rocks, Grapevine Canyon to La Luz ..................... 34

8. Map showing water table in the saturated basin-fill deposits, Grapevine Canyon to La Luz .............. 36

9. Map showing the thickness of sediments saturated with freshwater, Grapevine Canyon to La Luz .............40

10. Map showing the thickness of sediments saturated with slightly saline water, Grapevine Canyon to La Luz ..................................

11. Trilinear plots showing chemical composition of ground water, eastern side of the Tularosa Basin .... 44

12. Map showing water table in the saturated basin-fill deposits of the Rhodes Canyon alluvial fans, White Sands Missile Range

13. Geohydrologic sections $\mathrm{L}^{-\mathrm{L}^{\prime}}$ through $\mathrm{N}-\mathrm{N}^{\prime}$, Rhodes Canyon alluvial fans, White sands Missile Range ............48

14. Map showing water table in the saturated basin-fill deposits of the Ash Canyon alluvial fan, White Sands Missile Range .............................. 53

15. Geohydrologic sections $0-0^{\prime}$ and $\mathrm{P}-\mathrm{P}^{\prime}$, Ash Canyon alluvial fan, White Sands Missile Range ............ 54

16. Map showing thickness of sediments saturated with freshwater, Ash Canyon alluvial fan, White Sands Missile Range, 1981

17. Map showing location of potentially freshwaterbearing alluvial fans on the western side of the study area 
Figure 18. Graph showing results of an aquifer test, San Andres well 3, Holloman Air Force Base ................. 63

19. Map showing location of wells at White Sands Missile Range Post Headquarters and adjacent areas ..........6 65

20. Graph showing results of an aquifer test, well $\mathrm{NW}-30$, White Sands Missile Range .................... 71

21. Map showing location of At las and RATSCAT test wells in the vicinity of Holloman Air Force Base ......... 75

\section{TABLES}

Table 1. Well-record information, transmissivity estimates, and hydraulic-conductivity estimates of water-bearing zones in basin-fill deposits, Tularosa Basin .......... 91

2. Estimates of transmissivity calculated from specificcapacity data from wells in the Tularosa Basin ........ 93

\section{CONVERSION FACTORS}

In this report, figures for measurements are given in inch-pound units only. The following table contains factors for converting to metric units.

\begin{tabular}{|c|c|c|}
\hline Multiply inch-pound units & By & To obtain metric units \\
\hline inch & 25.4 & millimeter \\
\hline foot & 0.3048 & meter \\
\hline mile & 1.609 & kilometer \\
\hline foot per mile & 0.1894 & meter per kilometer \\
\hline foot per day & 0.3048 & meter per day \\
\hline foot squared per day & 0.0929 & meter squared per day \\
\hline acre-foot & 1,233 & cubic meter \\
\hline square mile & 2.590 & square kilometer \\
\hline gallon & 3.785 & liter \\
\hline gallon per minute & 0.0631 & liter per second \\
\hline Temperature in degrees & Fahrenheit & converted \\
\hline
\end{tabular}




\title{
WATER RESOURCES IN BASIN-FILL DEPOSITS
}

IN THE TULAROSA BASIN, NEW MEXICO

By Brennon R. Orr and Robert G. Myers

\begin{abstract}
The Tularosa Basin, a faulted intermontane depression in south-central New Mexico, contains a thick sequence of alluvial and lacustrine deposits of Tertiary and Quaternary age. Most of these sediments are saturated with very saline water. Freshwater supplies (dissolved-solids concentration less than 1,000 milligrams per liter) principally are found in alluvial fans located around the basin margin.

On the eastern side of the Tularosa Basin, fresh ground-water supplies are limited to alluvial-fan deposits from Grapevine Canyon to about 3 miles south of Alamogordo. Data from surface geophysical surveys indicate that about 1.4 to 2.1 million acre-feet of freshwater may be in storage in this area, not all of which is recoverable. An additional 3.6 to 5.4 million acre-feet of slightly saline water (dissolved-solids concentration 1,000 to 3,000 milligrams per liter) may be in storage in the same area, again not all of which is recoverable.

On the western side of the Tularosa Basin, alluvial fans in the vicinity of Rhodes Canyon may contain freshwater. Geophysical data indicate the freshwater zone may be as thick as 1,500 feet in places; however, the limited number of wells in this area precludes a precise definition of the volume of freshwater in storage. To the south, freshwater is present in alluvial fans associated with the Ash Canyon drainage system. Geophysical data indicate that perhaps as much as 450,000 acre-feet of freshwater, not all recoverable, may be in storage in this area. Fan deposits between Ash Canyon and Rhodes Canyon may contain additional freshwater supplies. Possibly 10.7 million acre-feet of freshwater, not all of which is recoverable, may be in storage on the western side of the Tularosa Basin.

Possibly 180 million acre-feet of brine (concentrations of dissolved solids exceeding 35,000 milligrams per liter), not all of which is recoverable, may be in storage in the Tularosa Basin. Information is sparse concerning the capability of saline aquifers in the Tularosa Basin to store and transmit fluid.
\end{abstract}


Five geohydrologic units that contain saline water are alluvial-fan deposits around basin margins, fluvial and eolian deposits in the southcentral part of the basin, underlying lacustrine deposits, near-surface evaporite deposits in the basin center, and deep-lying sand deposits. The estimated freshwater hydraulic conductivities of alluvial-fan deposits and fluvial and eolian deposits range from 1 to more than 300 feet per day; however, because of the larger kinematic viscosity of very saline water, the saline-water hydraulic conductivity of similar aquifers is smaller than the freshwater hydraulic conductivity. Water levels in these deposits respond to short-term pumping stress as if under leaky-confined conditions probably because thin interbedded clays restrict the vertical flow of water. Under long-term stress, the storage coefficient should approach the specific yield, which has been estimated to be between 8 and 15 percent.

Saturated sand units may comprise from 3 to 26 percent of lacustrine sediments. The hydraulic conductivity of these sand units may be about 1 foot per day, and the units probably respond to stress as leaky-confined aquifers.

The evaporite deposits of the central basin may be capable of yielding large volumes of very saline water. The extent and hydrologic properties of this saline aquifer are unknown. No hydrologic information is available concerning either the extent of the deep sand aquifer or its capability to store and transmit water. 


\section{INTRODUCTION}

Limited quantities of fresh and slightly saline water are present in alluvial-fan deposits along the margins of the Tularosa Basin. Much larger quantities of very saline water are present in thick deposits of fine-grained sediments in the central part of the basin. McLean (1970, p. 4) indicated that most of the saturated sediments in the Tularosa Basin contain water with concentrations of dissolved solids exceeding 35,000 milligrams per liter. Possibly less than 4 percent of the saturated sediments contains water with concentrations of dissolved solids less than 1,000 milligrams per liter. The U.S. Bureau of Reclamation, as part of the overall appraisal of water and energy resources in the Tularosa Basin, requires hydrologic information to define the potential for development of these resources.

\section{$\underline{\text { Purpose }}$}

The objectives of this study, conducted by the Geological Survey as part of the Bureau of Reclamation appraisal, are to: (1) Describe the distribution of fresh and slightly saline ground-water resources in basin-fill aquifers of the Tularosa Basin; (2) evaluate the capability of basin-fill aquifers to store and transmit water, particularly where these aquifers contain saline water; (3) estimate the amount of water in storage in basin-fill aquifers; and (4) establish a data base containing hydrologic information available from the Tularosa Basin.

\section{Location and Physiographic Setting}

Basin-fill deposits in the Tularosa Basin are located in parts of Doña Ana, Sierra, Otero, and Lincoln Counties, New Mexico ( $f i g \cdot 1$ ). Alamogordo is the principal center of population; smaller communities include Tularosa and Carrizozo. The economy primarily is centered on military bases in the area, consisting of Holloman Air Force Base, the White Sands Missile Range, and part of Fort Bliss.

The Tularosa Basin encompasses approximately 6,500 square miles in southcentral New Mexico and is an arcuate, downfaulted basin that extends northward approximately 170 miles from near the New Mexico-Texas state line. The basin is bounded on the east by the uplifted Sacramento Mountains and Sierra Blanca peak and on the west by the uplifted Franklin, Organ, and San Andres Mountains. Chupadera Mesa forms the northern basinal boundary, and a gentle topographic rise separates the basin from the Hueco Bolson to the south.

The study area (outlined in fig. 1) encompasses those areas of the Tularosa Basin known to contain a thick section of basin-fill deposits. The hydrology of the northern part of the Hueco Bolson, although not included in the study area, is briefly discussed because of the probability of hydrologic continuity between aquifers in both basins. 


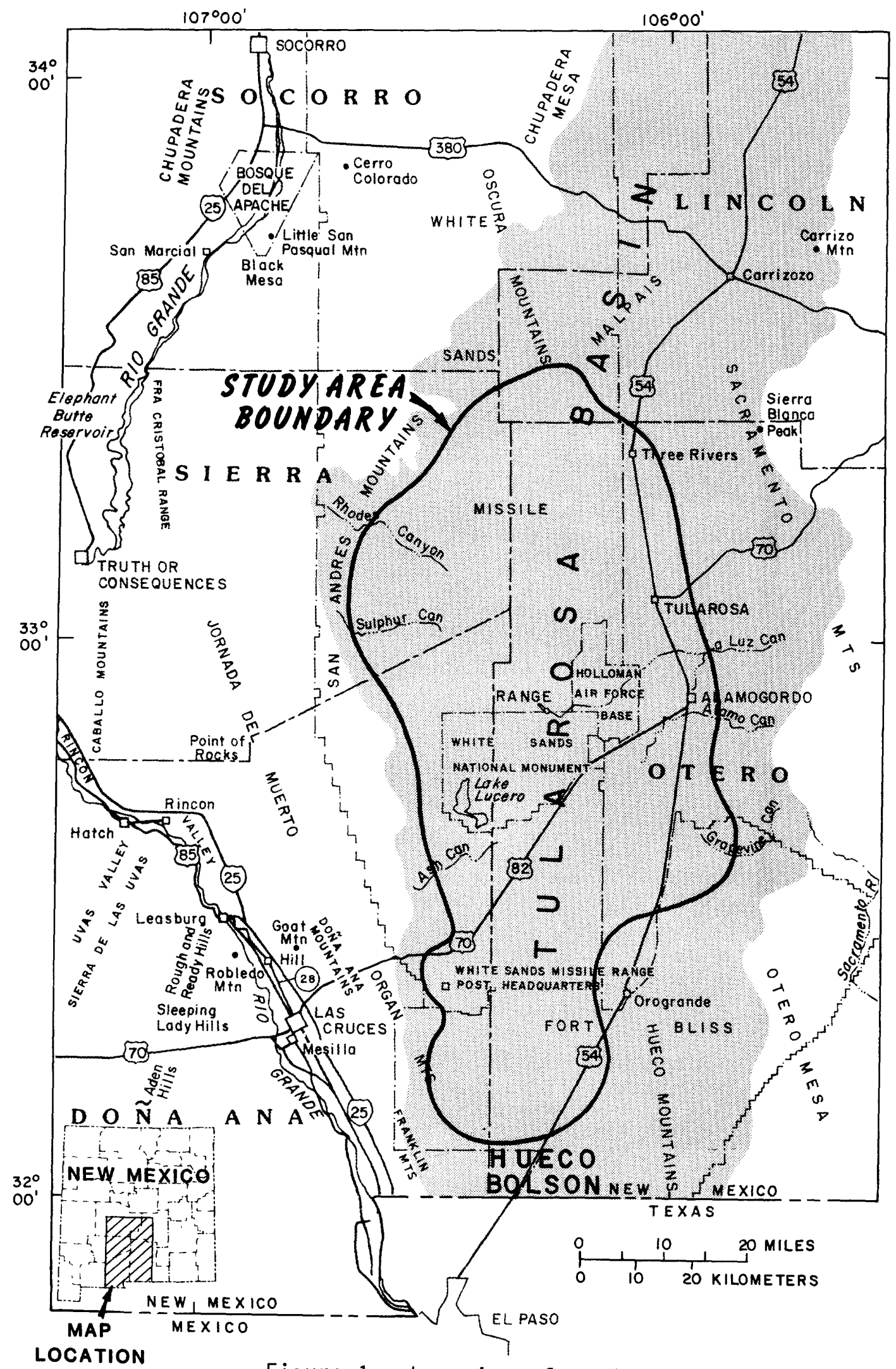

Figure 1.--Location of study area. 


\section{Previous Hydrologic Studies}

Herrick and others (1960) described ground-water resources of the Tularosa Basin. Mclean (1970) studied the saline ground-water resources of the Tularosa Basin and provided information on the fresh ground-water resources. The most recent and detailed report on the fresh ground-water resources on the eastern side of the Tularosa Basin is by Garza and McLean (1977).

Ground-water resources in the White Sands Missile Range Post Headquarters area have been described in reports by Weir (1965), Davis and Busch (1968), Zohdy and others (1969), Cooper (1970, 1973), Cruz (1972 through 1982), Kelly (1973), and Kelly and Hearne (1976). The ground-water resources of the northern end of the Hueco Bolson have been described in reports by knowles and Kennedy (1958) and by Wilson and Myers (1981).

\section{Approach}

In the present study, water is classified according to concentrations of dissolved solids as follows:

$$
\begin{aligned}
& \text { Freshwater--Contains less than } 1,000 \text { milligrams per liter dissolved } \\
& \text { solids. } \\
& \text { Slightly saline water--Contains from } 1,000 \text { to } 3,000 \text { milligrams per } \\
& \text { liter dissolved solids. } \\
& \text { Moderately saline water--Contains from } 3,000 \text { to } 10,000 \text { milligrams per } \\
& \text { liter dissolved solids. } \\
& \text { Very saline water--Contains from } 10,000 \text { to } 35,000 \text { milligrams per liter } \\
& \text { dissolved solids. } \\
& \text { Brine--Contains more than } 35,000 \text { milligrams per liter dissolved } \\
& \text { solids. }
\end{aligned}
$$

The distribution of freshwater and slightly saline water resources was evaluated through the use of surface electrical-resistivity soundings in alluvial-fan areas on the eastern and western sides of the Tularosa Basin. Many of these areas have little or no ground-water development, and surface electrical-resistivity soundings permitted a large-scale reconnaissance of potential fresh and slightly saline ground-water resources. Collection and reduction of surface electrical-resistivity data was performed under the direction of Robert J. Bisdorf, Branch of Geophysics, Geologic Division, U.S. Geological Survey. A comprehensive drilling program was beyond the scope of the present study.

Surface electrical-resistivity data were used in conjunction with available well data as well as gravity, seismic, and borehole-geophysical data to construct geohydrologic sections and maps. From these sources, the thickness and lateral extent of sediments saturated with fresh and slightly saline water and the location of water-quality interfaces in the basin were estimated. 
Surface electrical-resistivity soundings were made to provide hydrologic data for large areas where more costly exploratory techniques would have been prohibitive. Resistivity data, where possible, were correlated with existing well data. A number of geohydrologic sections were constructed using these data from which estimates of the interfaces between saline water and freshwater, freshwater volumes, and depths to bedrock could be made in areas where ground-water data previously were minimal. However, in some areas where a lack of wells precluded correlation with the resistivity data, geohydrologic sections were constructed using well data extrapolated from other areas. In order to more accurately define the hydrology and geology along these sections, test drilling is necessary.

Surface-resistivity sounding curves constructed from field data were of good quality with the exception of several that may have been affected by lateral inhomogeneities in the geologic section or by nearby surface conditions. Layered values of interpreted true resistivity were obtained from these curves using methods described by Zohdy and others (1969, p. 6-9). These values were plotted on geohydrologic sections along with available well information.

The interpreted true resistivity of saturated basin-fill deposits decreases with depth as a function of the increase in the dissolved-solids concentration in ground water. Water-quality zones are delineated from changes in the interpreted true resistivity and, whenever possible, from water-chemistry analyses. The interpreted true resistivity begins to increase at the interface between basin-fill deposits and consolidated rock. The depth to the top of consolidated rock is estimated from those soundings for which this increase in interpreted true resistivity is evident.

In this report, surface resistivities greater than 60 ohmmeters are classified as high; resistivities between 15 and 60 ohmmeters are classified as moderate; and resistivities less than 15 ohmmeters are classified as low. High resistivities may indicate consolidated bedrock, unsaturated alluvium, or very coarse alluvial deposits (boulders) saturated with fresh to slightly saline water. Moderate resistivities may indicate alluvial deposits (sands and gravels) saturated with fresh or slightly saline water. Low resistivities may indicate either $c$ lay and other fine-grained sediments or alluvial deposits saturated with saline or slightly saline water. Because of the large number of alternative geohydrologic conditions that could account for a specific surface-resistivity value and because of the absence of deep-well information, the water-chemistry zones, lithologic units, and bedrock configuration are only approximately delineated in many areas.

Surface-resistivity measurements indicated that the altitude of consolidated bedrock changes abruptly from place to place. These abrupt lateral changes were tentatively interpreted as a series of bedrock step faults associated with border fault zones on the margin of the Tularosa Basin. This interpretation is not verified by any deep drill-hole information. 
The second objective of the study consisted of an appraisal of the capability of aquifers in the basin to store and transmit saline water. This part of the study included an analysis of the limited amount of hydrologic and geologic information available from saline-water wells and the collection and analysis of aquifer-test data.

The transmissivity of an aquifer is the rate at which water is transmitted through a unit width of the aquifer under a unit hydraulic gradient. Transmissivity can be determined by analyses of data obtained from tests in which the aquifer is stressed and the resulting effect on the potentiometric surface is measured.

The Theis solution for transmissivity has been used extensively in analyses of aquifer-test data in the Tularosa Basin. The Theis equation assumes that the aquifer is isotropic and homogeneous, that flow to the well is radial, and that the well fully penetrates the aquifer. None of these assumptions are met in the Tularosa Basin. Basin-fill aquifers generally consist of a heterogeneous mix of bedded sand, gravel, and clay. Thin, permeable sand units are interbedded with less permeable clay and silt units. The interbedded clays within the aquifer significantly reduce the vertical movement of water; consequently, the ratio of vertical to horizontal flow within the aquifer is probably very small in most areas of the Tularosa Basin. Because of the low ratio of vertical to horizontal movement of water in basin-fill aquifers, flow probably is radial only in the thickness of aquifer opposite the production interval in the well. Finally, wells generally penetrate only a partial thickness of the total aquifer.

Transmissivity estimates can be made using measurements of water-level drawdown in the pumped well or in nearby observation wells in response to the withdrawal of water. In the Tularosa Basin, most test data are from pumping wells. These test data are affected not only by incomplete penetration of the aquifer by the well and by aquifer anisotropy, but also by well losses due to turbulent flow in the well bore.

Although basin-fill sediments generally respond to stress as leakyconfined aquifers, the short-term effect of leakage probably is negligible on water levels in the pumping well. In single-well tests in the Tularosa Basin, the Theis solution for estimating transmissivity probably provides the most precise estimate of the capability of the part of the aquifer opposite screened intervals to transmit water.

Hydraulic conductivity defines the capability of a unit thickness of an aquifer to transmit water. Previous attempts to estimate hydraulic conductivity in basin-fill sediments of the Tularosa Basin have consisted of dividing estimates of transmissivity by the total saturated thickness of the aquifer. The assumption was made in these attempts that the estimated transmissivity represented the entire saturated thickness, but this may not be the situation. Because of the very small ratio of vertical to horizontal hydraulic conductivity of basin-fill deposits, previous transmissivity estimates probably represent conditions directly opposite the screened 
interval. In this study, hydraulic-conductivity estimates were made by dividing the transmissivity by the total saturated-sand thickness of the production intervals. The sand thickness was determined from geophysical logs. These estimates were then extrapolated to untested sections of the aquifer to provide a probable maximum transmissivity of the total saturated thickness.

A near-saturated (25 percent by volume) sodium chloride brine at $20^{\circ}$ Celsius has a density of about 1.19 milligrams per milliliter and contains about 189,000 milligrams per liter dissolved solids. The kinematic viscosity of this brine is about 1.6 times that of pure water (Weist, 1983, p. D-262). According to Darcy's law, hydraulic conductivity is inversely proportional to the kinematic viscosity. Theoretically, the average hydraulic conductivity of an aquifer saturated with a sodium chloride brine could be as small as 0.6 times that of a similar aquifer saturated with freshwater. In the Tularosa Basin, aquifer-test data primarily are from wells producing freshwater (less than 1,000 milligrams per 1iter). Saline ground water in the basin is characterized by a wide range of dissolved-solids concentrations and by a correspondingly wide range of kinematic viscosities greater than that of freshwater. Consequently, the hydraulic-conductivity estimates from freshwater areas are maximum limits and saline-water aquifers of similar lithologic composition probably will be characterized by smaller hydraulicconductivity estimates as a function of the fluid viscosity. In this report, the extrapolated hydraulic-conductivity values should be treated only as maximum approximations until more accurate values can be obtained from aquifer tests in the previously untested areas.

The third objective of the study was to estimate the amount of water in storage in basin-fill aquifers of the Tularosa Basin. Estimates of volumes of freshwater, slightly saline water, moderately saline water, very saline water, and brine were made based on saturated-thickness maps, geophysical-survey data, existing aquifer-property data, and water-quality data from the present study and from previous studies.

The fourth objective of the study base for ground-water information from studies. Available hydrologic data are

consisted of establishment of a data published and unpublished hydrologic Ground-Water Site-Inventory file (GWSI). 


\section{We11-Numbering System}

The system of numbering welis in New Mexico is based on the common subdivision of public lands into sections. The well number, in addition to designating the well, locates its position to the nearest 10-acre tract in the land network (fig. 2). The well number is divided by periods into four segments. The first segment denotes the township north or south of the New Mexico Base Line; the second denotes the range east or west of the New Mexico Principal Meridian; and the third denotes the section. The fourth segment of the number, which consists of three digits, denotes the 160-, 40-, and 10-acre tracts in which the well is situated in the section. For this purpose, the section is divided into four quarters, numbered $1,2,3$, and 4, for the northwest, northeast, southwest, and southeast quarters, respectively. The first digit of the fourth segment gives the quarter section, which is a tract of 160 acres. Similarly, the quarter section is divided into four 40-acre tracts numbered in the same manner, and the second digit denotes the 40-acre tract. Finally, the 40-acre tract is divided into four 10-acre tracts, and the third digit denotes the 10-acre tract. Thus, well 17S.10E.31.424 is in the $\mathrm{SE} \frac{1}{4}$ of the $\mathrm{NE} \frac{1}{4}$ of the $\mathrm{SE} \frac{1}{4}, \mathrm{sec} .31, \mathrm{~T} .17 \mathrm{~S} ., \mathrm{R}, 10 \mathrm{E}$. If a well cannot be located accurately within a 10-acre tract, a zero is used in place of the last digit. Letters $a, b, c, d$, and $e$ are added to the last segment to designate the second through the sixth wells in the same 10-acre tract. All wells in the study area are in townships south of the base line and east of the meridian line; therefore, the $S$ and $E$ are left out of the well number in this report.

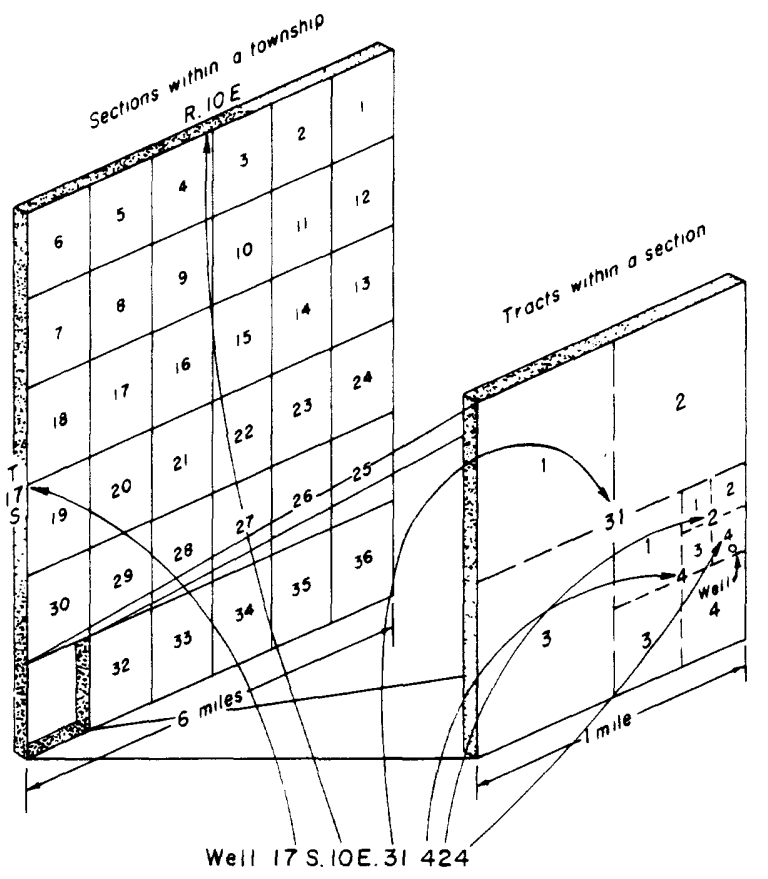

Figure 2,--System of numbering wells. 


\section{GEOHYDROLOGIC FRAMEWORR}

\section{Paleozoic and Mesozoic Rocks}

Middle to late Cenozoic faulting formed the structural trough known as the Tularosa Basin. This faulting exposed Precambrian- through Tertiary-age igneous and sedimentary rocks along the scarps bounding the basin floor (fig. 3). These same rocks underlie the Cenozoic fill deposits in the Tularosa Basin. Some of these Paleozoic and Mesozoic rocks are known to yield small quantities of water to wells in areas adjacent to the basin, but are not considered to be major aquifers in the area of study. The lithologic and water-bearing characteristics of these rocks were briefly described by McLean (1970, p. 10-16) and are not discussed in this report except in the explanation for figure 3 .

\section{Cenozoic Deposits}

Deposition of alluvial fill accompanied the middle and late Cenozoic faulting of the Tularosa Basin. Fill deposits shown in figure 3 as bolson deposits and dune deposits included gravel, sand, and clay in alluvial fans along basin margins and extensive lacustrine, alluvial, and evaporite deposits of the interior basin. Limited quantities of freshwater in the fan deposits supply many of the freshwater needs in the basin. Large quantities of saline water occur within most of the Tularosa Basin sediments. This study describes the extent of selected freshwater supplies in these deposits and the hydrologic characteristics of fill deposits that contain saline water.

\section{Stratigraphic Relationships of Basin-Fill Hydrologic Units from Geophysical Studies and Well Data}

Well data describing the lithologic characteristics of deposits in the Tularosa Basin are limited, particularly at depth. Some data are available in the relatively shallow subsurface where development of freshwater supplies has occurred. Stratigraphic test well T-14 (22.5.15.221), drilled on White Sands Missile Range in 1967, is one of the few sources for deep-well information.

Test well T-14 was drilled to evaluate the availability of water from the deeper sections of basin-fill deposits, to determine the thickness of basin fill and depth to bedrock, and to describe the lithologic composition of basin-fill deposits. This test well, drilled to a depth of 6,015 feet, was one of the deepest test wells in the Tularosa Basin, and provided at least some understanding of the lithologic and geohydrologic units that may occur extensively at depth throughout the basin.

Borehole-geophysical logs of well T-14 are available from a depth of 400 feet (bottom of surface casing) to the total logged depth of 5,972 feet (Doty and Cooper, 1970). Doty and Cooper (1970) also presented a lithologic log from the land surface to the total drilled depth of 6,015 feet. 
Definite stratigraphic changes can be observed from geophysical and lithologic logs of well T-14. The lithologic log shows that coarse-grained sand, silt, clay, and gravel were penetrated to a depth of about 180 feet. From 180 feet to the top of the geophysical-log interval ( $400 \mathrm{feet}$ ), clay is the predominant lithology. According to the proximity microlog, the interval from 400 feet (depth of surface casing) to 2,801 feet predominantly consists of clay; about 26 percent of this interval is thinly bedded, fine-grained sand. Sand beds range in thickness from 2 to 30 feet. From 2,801 to 3,176 feet, clay is predominant again, although thinly bedded, medium-grained sand units, from 2 to 12 feet thick, comprise approximately 23 percent of this interval. The interval from 3,176 to 3,620 feet consists entirely of clay. The proximity microlog indicates that no permeable zones are present in this interval. The interval from 3,620 to 4,007 feet predominantly consists of sand interbedded with clay; sand beds range in thickness from 2 to 28 feet. From 4,007 feet to the total logged depth, sand predominates, interbedded with only a few thin clay beds ranging from 2 to 6 feet thick. The porosity log indicates the total porosity is relatively larger than that of the overlying sand-clay unit.

The lithologic sequence penetrated in well T-14 can be correlated with data from other shallower wells in the Tularosa Basin and may be representative of basin-fill sediments throughout the Tularosa Basin. A similar sequence was observed in a deep test well drilled by the city of El Paso in the northern part of the Hueco Bolson. This test well, located about 3 miles south of the New Mexico-Texas State line and about 4 miles east of the Franklin Mountains, was drilled to a depth of 4,363 feet and penetrated sand and gravel to a depth of 600 feet, sand and clay from 600 to 2,300 feet, and clay with evaporites from 2,300 feet to the total depth (Gates and others, 1980, p. 93).

\section{Delineation of Basin-Fill Hydrologic Units}

Remote-sensing techniques such as Landsat imagery can provide a surficial overview of the distribution of unconsolidated sediments within the Tularosa Basin. Landsat imagery of the basin was used to delineate areas based on probable differences in soil type and vegetation (fig. 4). These differences can be correlated with changes in soil types noted on soil-mapping surveys (Neher and Bailey, 1976; Derr, 1981) and with changes in composition and texture of underlying sediments observed from test-well data.

Coarse- to fine-grained sediments occur around the margins of the Tularosa Basin in a series of coalescing alluvial fans (QTaf, fig. 4). These fans were formed from detritus derived from source areas in the bordering mountains. Fan areas appear as dark- to light-gray areas on Landsat colorcomposite imagery. The sizes of individual fans vary depending on the sizes of the drainage areas supplying them. These fan deposits occur in the subsurface as pediment deposits or thin veneers overlying bedrock (as occurs in the White sands reentrant) and as thicker units basinward where they intertongue with central-basin lacustrine and alluvial deposits. 


\section{EXPLANATION}

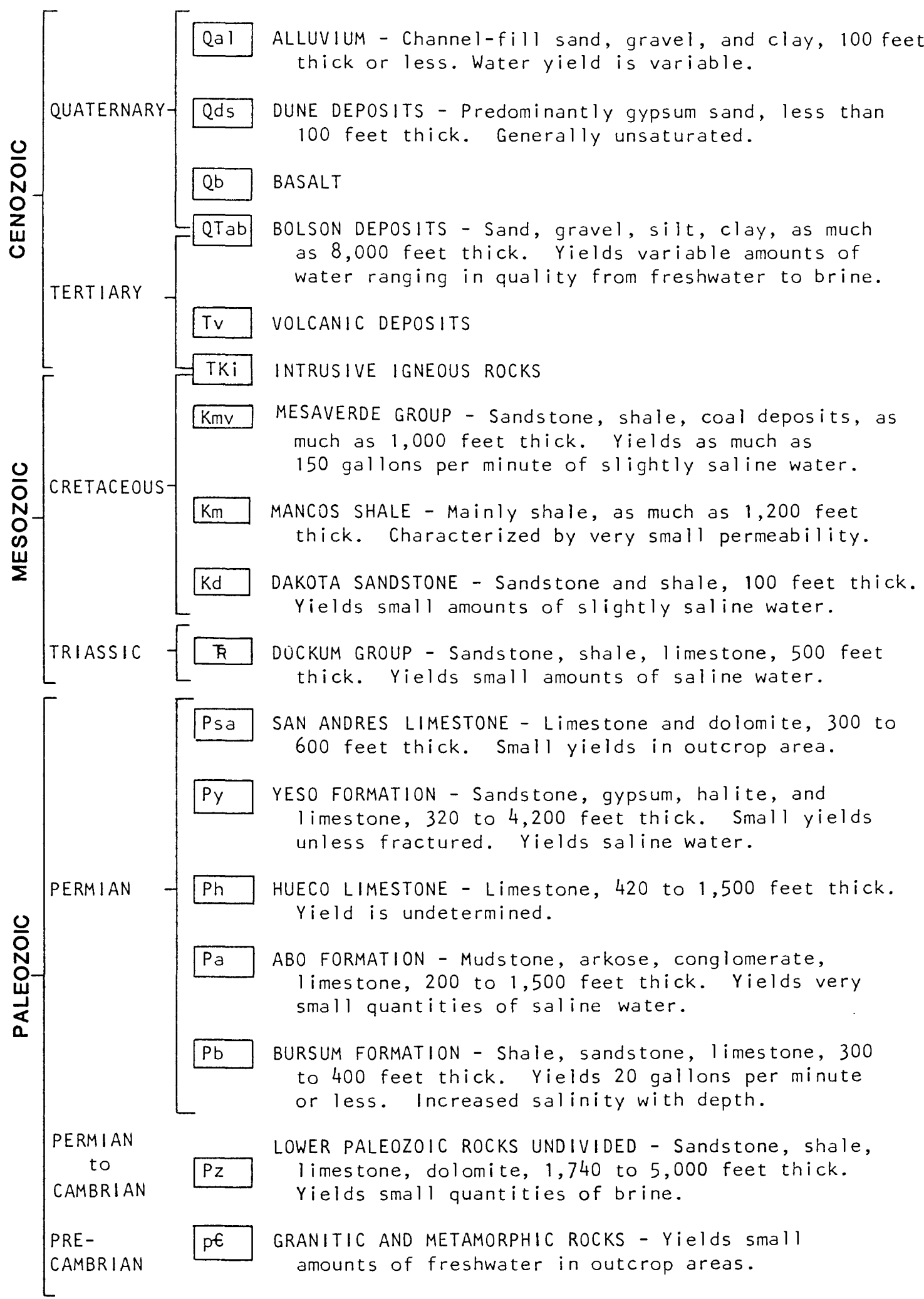




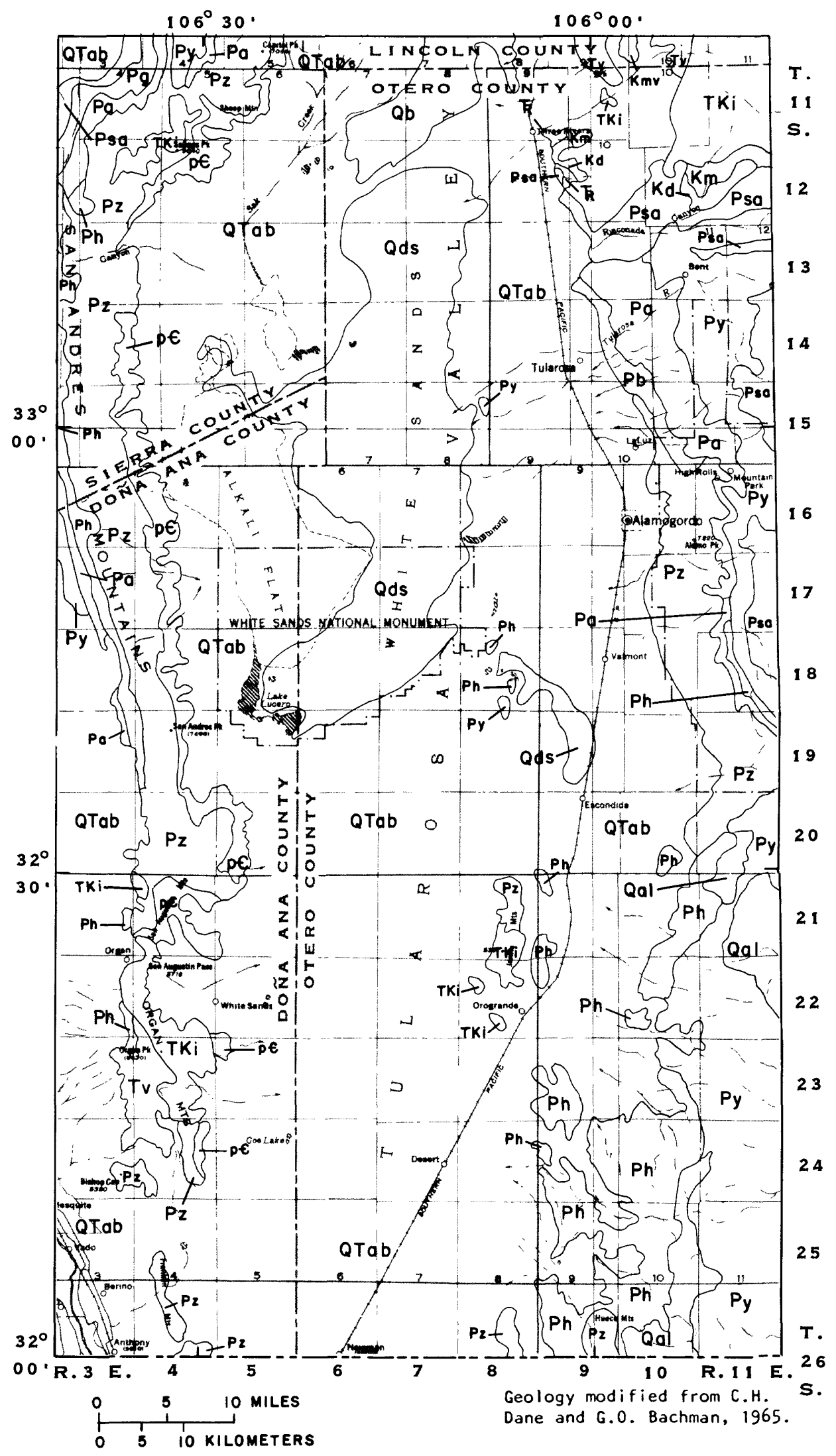

Figure 3.--Geology of the southern part of the Tularosa Basin. 


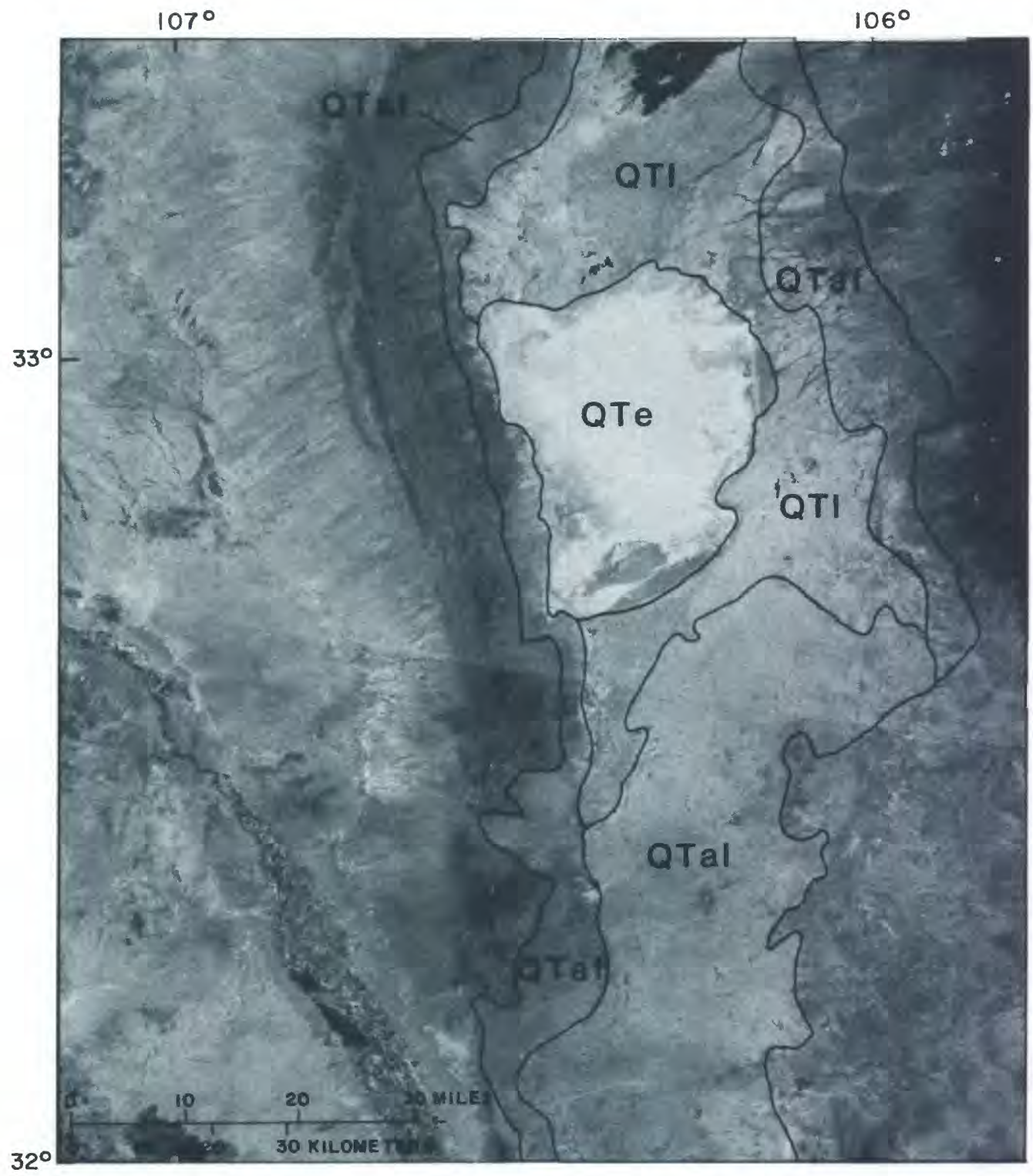

DESCRIPTION OF QUATERNARY AND TERTIARY GEOLOGIC UNITS

QTaf ALLUVIAL FAN DEPOSITS--Consist of sand, gravel, QTI silt and clay; saturated in places with fresh to saline water.

QTaI CENTRAL BASIN ALLUVIAL DEPOSITS--Consist of sand, gravel, silt, and clay; saturated with saline water.
LACUSTRINE DEPOSITS--Predominantly clay with

QTe EVAPORITE DEPOSITS--Predominantly consist of recrystallized gysum underlying alkali flats and White Sands dune area; saturated with saline water.

- CONTACT--Approximate surficial extent of specific hydrologic units as inferred from Landsat data and from soils survey data (Bulloch and Neher, 1980; Derr, 1981; Neher and Bailey, 1976).

Figure 4.--Basin-fill hydrologic units of the southern part of the Tularosa Basin. Landsat photomap by National Oceanic and Atmospheric Administration. Landsat imagery by National Aeronautics and Space Administration, 1973. 
An area (QTal, fig. 4) southeast of Highway 70 and extending south past the New Mexico-Texas State line, east to the Grapevine Canyon alluvial fan, and west to the Organ Mountain and Franklin Mountain alluvial fans can be defined by color changes on Landsat imagery. Soil maps indicate that this area has soils largely derived from fluvial and eolian deposits (Neher and Bailey, 1976; Derr, 1981).

These fluvial and eolian deposits may be correlated with the coarser grained sediments penetrated in the shallow subsurface in the southern part of White Sands Missile Range and on Fort Bliss. At least 500 feet of sand, gravel, and clay were penetrated in the upper part of the Gregg test and supply wells (22.6.8.414 and 414a); approximately 180 feet of these sediments were penetrated in we11 $\mathrm{T}-14(22.5 .15 .221)$. As much as 600 feet of sand and gravel were penetrated in the El Paso deep test well in the northern part of the Hueco Bolson. According to geophysical and lithologic logs, similar deposits of sand, gravel, and clay were penetrated by other wells in the southern part of the Tularosa Basin and northern part of the Hueco Bolson. Knowles and Kennedy (1958, p. 18) indicated that the Franklin and Organ Mountains provide the main source of these deposits and that they grade from thick, coarse sediments near the mountains to thin, fine-grained sediments to the east near the Hueco Mountains. These deposits are capped in places with a thin veneer of dune sand.

Landsat imagery indicates an area north of the fluvial and eolian deposits of the south-central basin ( $f i g .4$ ) that corresponds closely to areas on soil-survey maps where soils are derived from gypsiferous deposits. These deposits (QT1) largely consist of clay and evaporites related to the lacustrine sediments typically occurring in closed depositional basins.

These very fine grained deposits may extend throughout most of the basin. Underlying the fluvial-eolian and alluvial deposits to the south, a thick section predominantly consisting of clay was penetrated in the Gregg wells from a depth of 500 feet to the total depth of 1,000 feet. Test well T-14 penetrated clay with some sand interbeds from 180 to 3,176 feet and clay froin 3,176 to 3,620 feet. The El Paso deep-test well penetrated sand and clay from 600 to 2,300 feet and clay from 2,300 feet to the total drilled depth of 4,363 feet. Similar, fine-grained material (predominantly clay) was penetrated at depth in other wells on White Sands Missile Range and on Fort Bliss.

The present-day playa lake bed of Lake Lucero, alkali flats to the north, and the gypsum dunes of White Sands National Monument lie within the area delineated by the gypsiferous evaporite deposits (QTe, fig. 4). Much of this area is underlain by a unit predominantly consisting of dense, recrystallized gypsum. Allmendinger and Titus (1973) reported from 10 to 25 feet of gypsum in the Lake Lucero area. A test well (16.6.32.241) located in the alkali flats north of Lake Lucero penetrated approximately 160 feet of recrystallized gypsum before entering clay. Similar thicknesses probably $c a n$ be expected elsewhere in the evaporite-deposit area. 
The coarse-grained sand penetrated in the lower 2,400 feet of we11 T-14 may be laterally extensive in the deeper parts of the Tularosa Basin. However, no other deep lithologic information is available elsewhere to verify this possibility.

These five depositional units, which are the alluvial fans bordering the basin, the fluvial-eolian sand, gravel, and clay deposits of the southern part of the basin, the thick lacustrine deposits occurring at the surface in the north part of the basin and at depth in the south part of the basin, the gypsum-playa deposits in the Lake Lucero-White Sands area, and possibly extensive coarse-grained deposits penetrated in the lower 2,400 feet of well T-14, probably are representative of the types of deposits that are saturated with saline water in the central Tularosa Basin.

\section{DISTRIBUTION OF WATER QUALITY IN BASIN-FILL DEPOSITS}

In the Tularosa Basin, ground water with dissolved-solids concentrations less than 1,000 milligrams per liter (freshwater) occurs high in the alluvial fans adjacent to points of recharge along mountain fronts. This water is used extensively for public supply. Dissolved-solids concentrations in ground water increase basinward and with depth, and a transition zone of water containing concentrations of dissolved solids from 1,000 to 3,000 milligrams per liter (slightly saline water) is used for irrigation supply in some areas. Moderately saline to very saline water occurs basinward and with increasing depth.

\section{Fresh and Slightly Saline Water in Alluvial Fans}

Surface electrical-resistivity surveys have been used to define the extent of fresh and slightly saline ground-water supplies. Previous surface electrical-resistivity surveys included 85 soundings on parts of White Sands Missile Range and Fort Bliss (Zohdy and others, 1969). In 1982, the Geological Survey made 80 soundings in areas extending from the village of La Luz to the Grapevine Canyon alluvial fan on the eastern side of the basin (fig. 5) and in the Rhodes Canyon and Ash Canyon alluvial fans on the western side of the basin (fig. 1). These alluvial-fan areas were selected for hydrologic study because tributary drainages contributing recharge water to them are moderately large and because these fans may contain useable quantities of freshwater. 


\section{Eastern Side of the Tularosa Basin}

Limited freshwater resources occur in alluvial deposits of Three Rivers and Rinconada Creek north of Tularosa. Most of the freshwater on the eastern side of the basin occurs in alluvial fans south of Alamogordo.

\section{Three Rivers and Rinconada Creek}

Alluvial deposits in the Three Rivers and Rinconada Creek areas are recharged from large surface drainages but these areas probably contain minimal quantities of fresh ground water. Hood and Herrick (1965) indicated that some fresh ground water may occur in the Three Rivers reentrant, but that alluvial deposits probably are less than 300 feet thick and are characterized by small yields and in most places by slightly saline water. Water in alluvial fans of the Rinconada Creek area may be similar to that in the Three Rivers reentrant.

\section{Grapevine Canyon to La Luz}

Eleven east-west geohydrologic sections were constructed in the area extending from the vicinity of Grapevine Canyon to the village of La Luz; the traces of these sections are shown in figure 5 and the sections are shown in figure 6. These geohydrologic sections include data obtained from 56 surface electrical-resistivity soundings and water-level, water-chemistry, and lithologic data from wells in the area. The sections extend across alluvialfan deposits westward from the Sacramento Mountains and show the approximate thickness of basin-fill deposits, approximate location of water-chemistry zones as defined by dissolved-solids concentrations in ground water, and the probable configuration of the surface of the consolidated bedrock. 


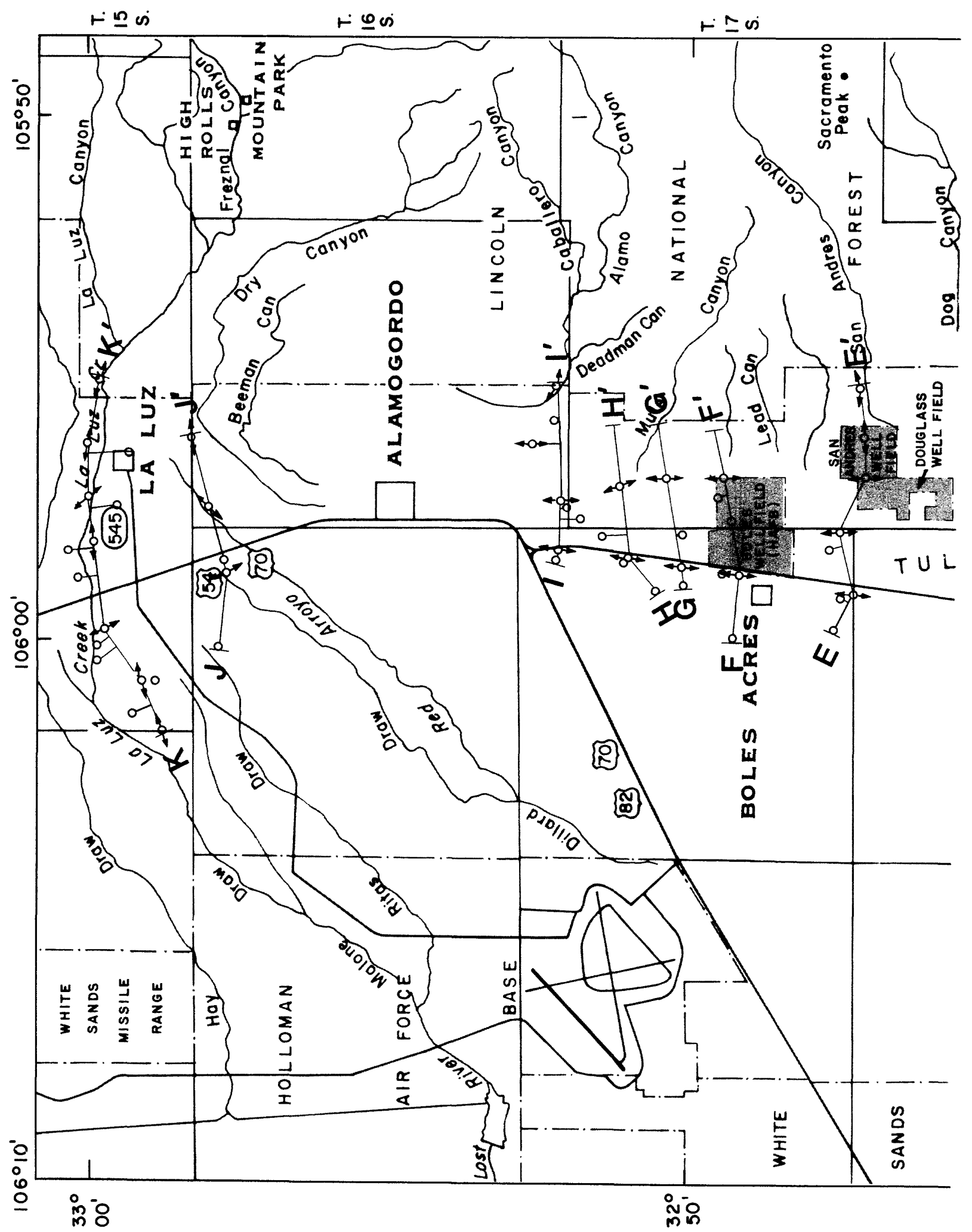




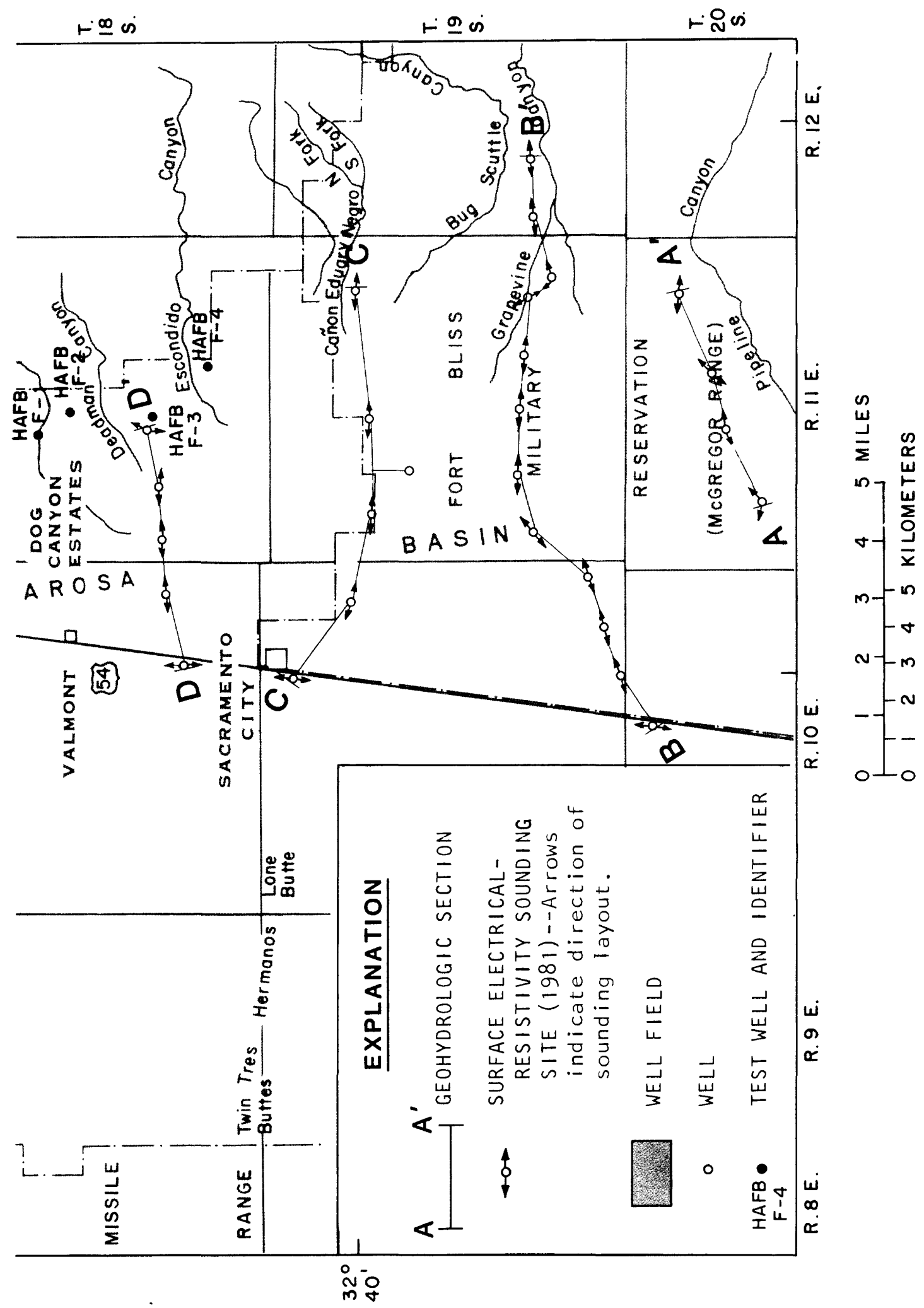

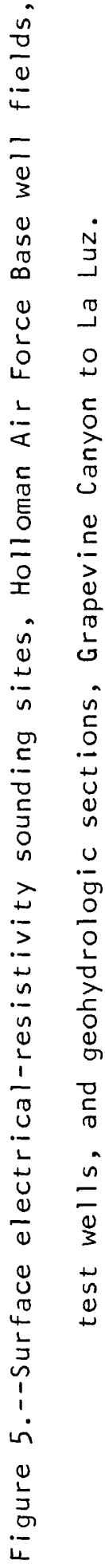




\section{EXPLANATION}

\section{GEOLOGIC DATA}

QTab BOLSON DEPOSITS--Pleistocene to middle Miocene basin-fill deposits composed of clay, silt, sand, and gravel.

Tpe CONSOLIDATED BEDROCK--Tertiary to Precambrian rocks consisting of sedimentary, metamorphic, and igneous rocks. Includes undifferentiated volcanic and intrusive rocks.

INFERRED CONTACT

\section{WATER-QUALITY DATA}

ESTIMATED CONCENTRATION OF DISSOLVED SOLIDS IN WATER, IN MILLIGRAMS PER LITER, AND WATER-QUALITY ZONES (A) $)$ contacts between water-quality zones are gradational).

MII

::a:: 1000 to 3000 - Slightly saline water

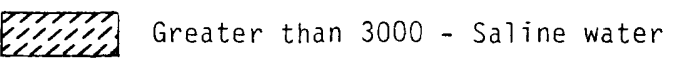

\section{WELL DATA}

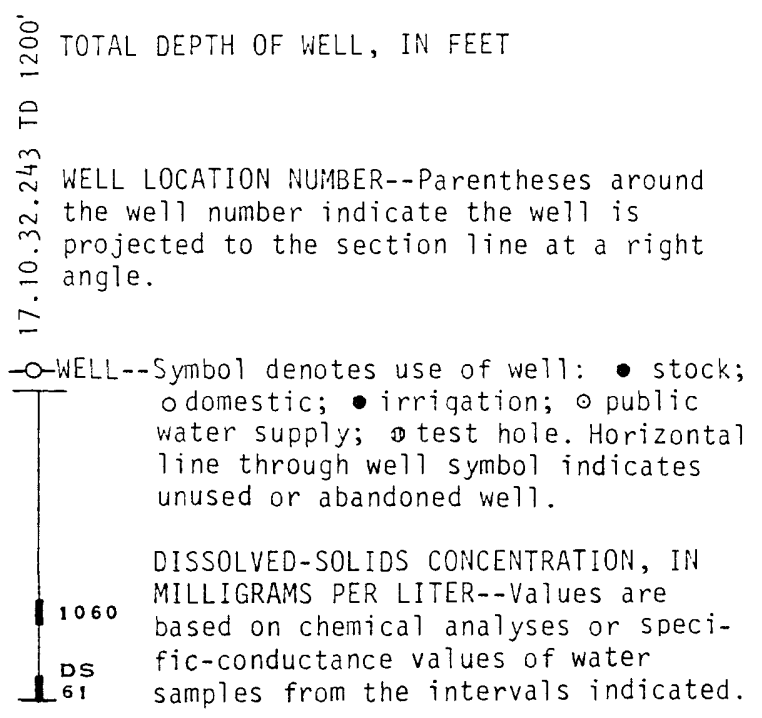

\section{VERTICAL ELECTRICAL-SOUNDING}

DATA

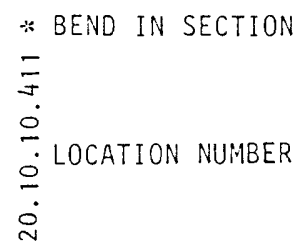

$\Xi$

$\stackrel{\circ}{\circ}$

$\because$ LOCATION NUMBER

웅

$X$ VERTICAL ELECTRICAL SOUNDING

\pm 109 RESISTIVITY--Number is the true

$+\mathbf{5} 2$ resistivity, in ohmmeters, of

$+\mathbf{2 8}$ interval. Intervals separated by $\perp$.

Figure 6.--Geohydrologic sections A-A' through K-K', Grapevine Canyon to La Luz. 


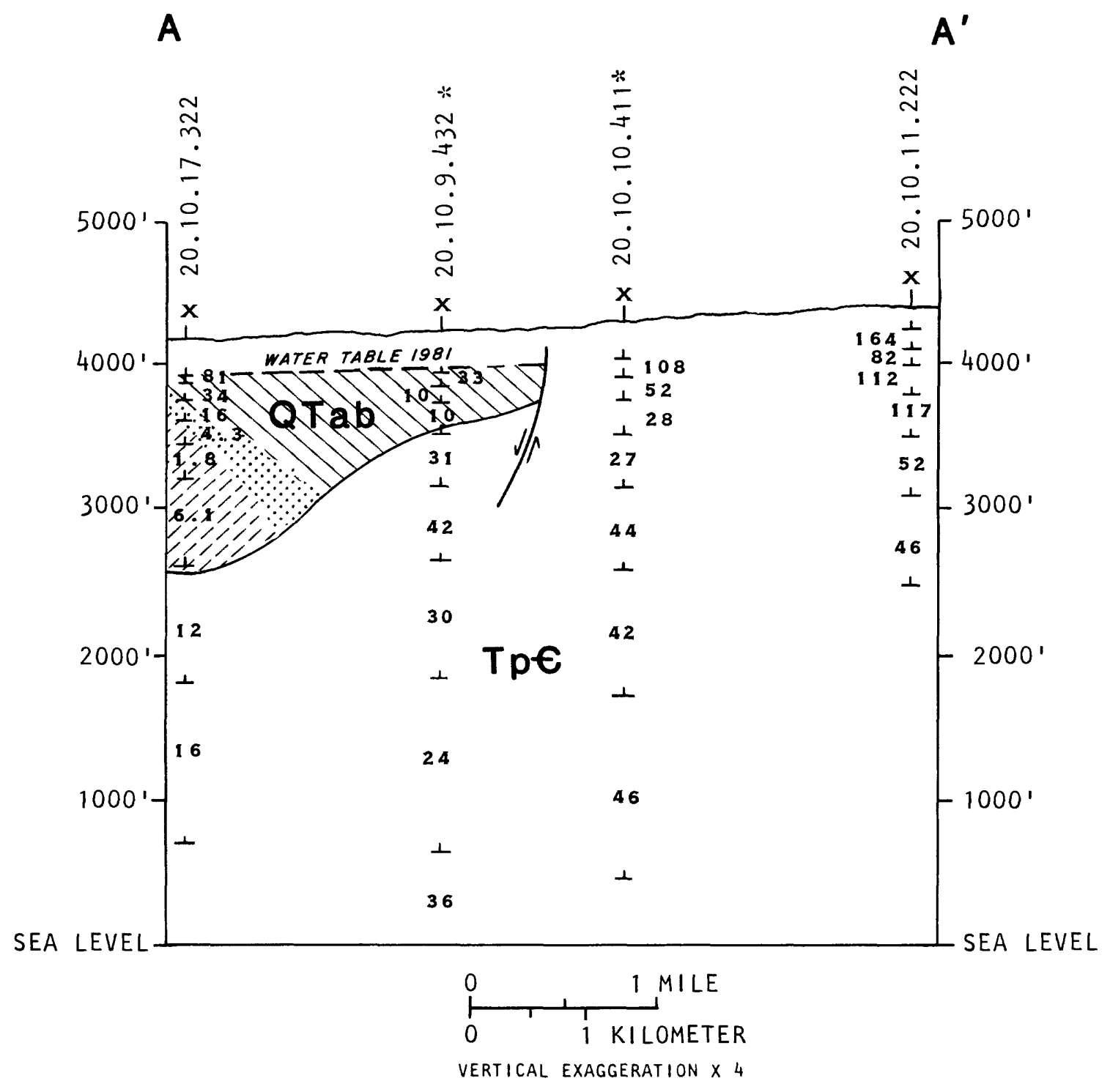

Figure 6.--Geohydrologic sections $A-A^{\prime}$ through $K-K^{\prime}$, Grapevine Canyon to La Luz - Continued. 
B

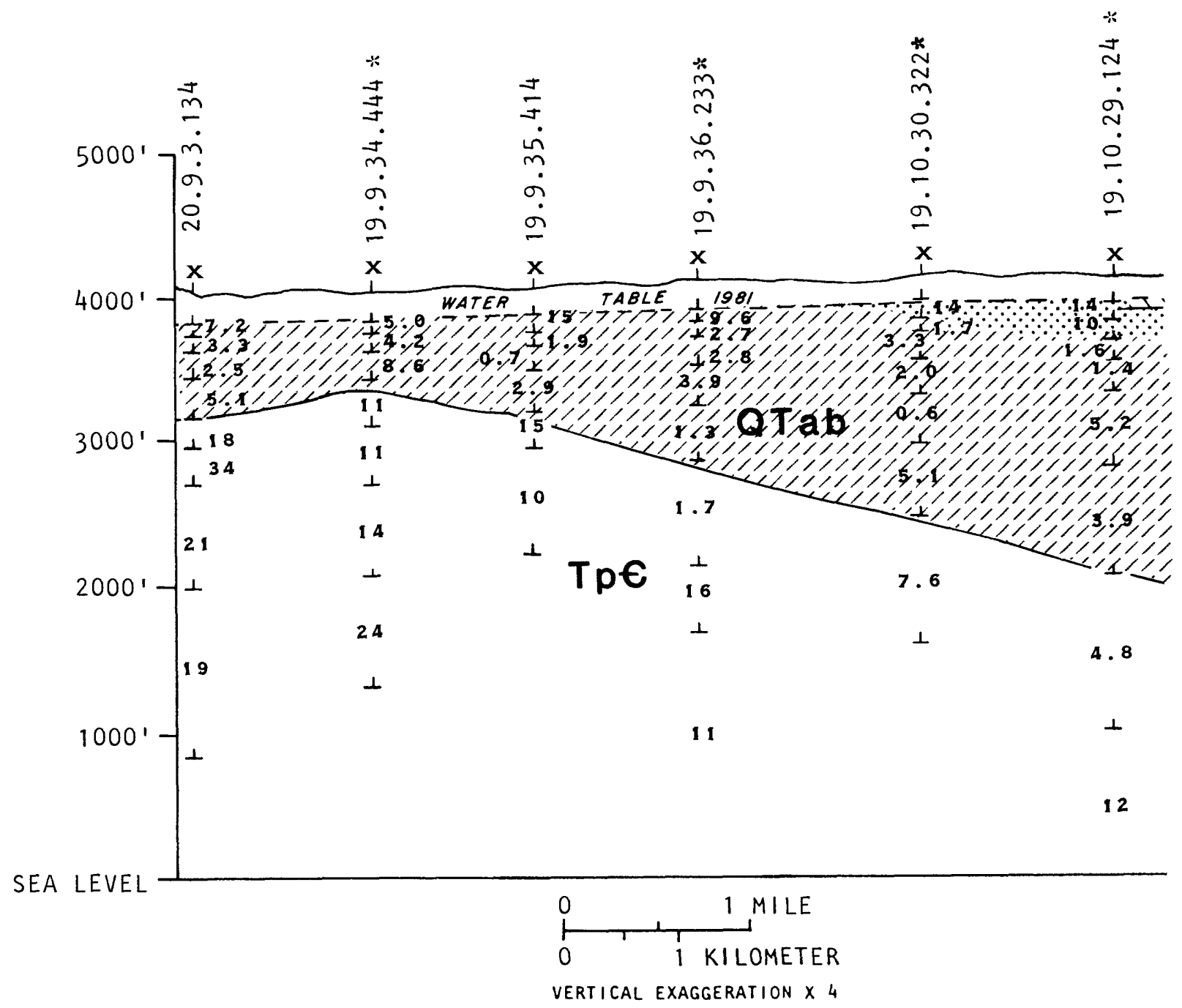

Figure 6.--Geohydrologic sections $A-A^{\prime}$ through $K-K^{\prime}$, Grapevine Canyon to La Luz - Continued. 


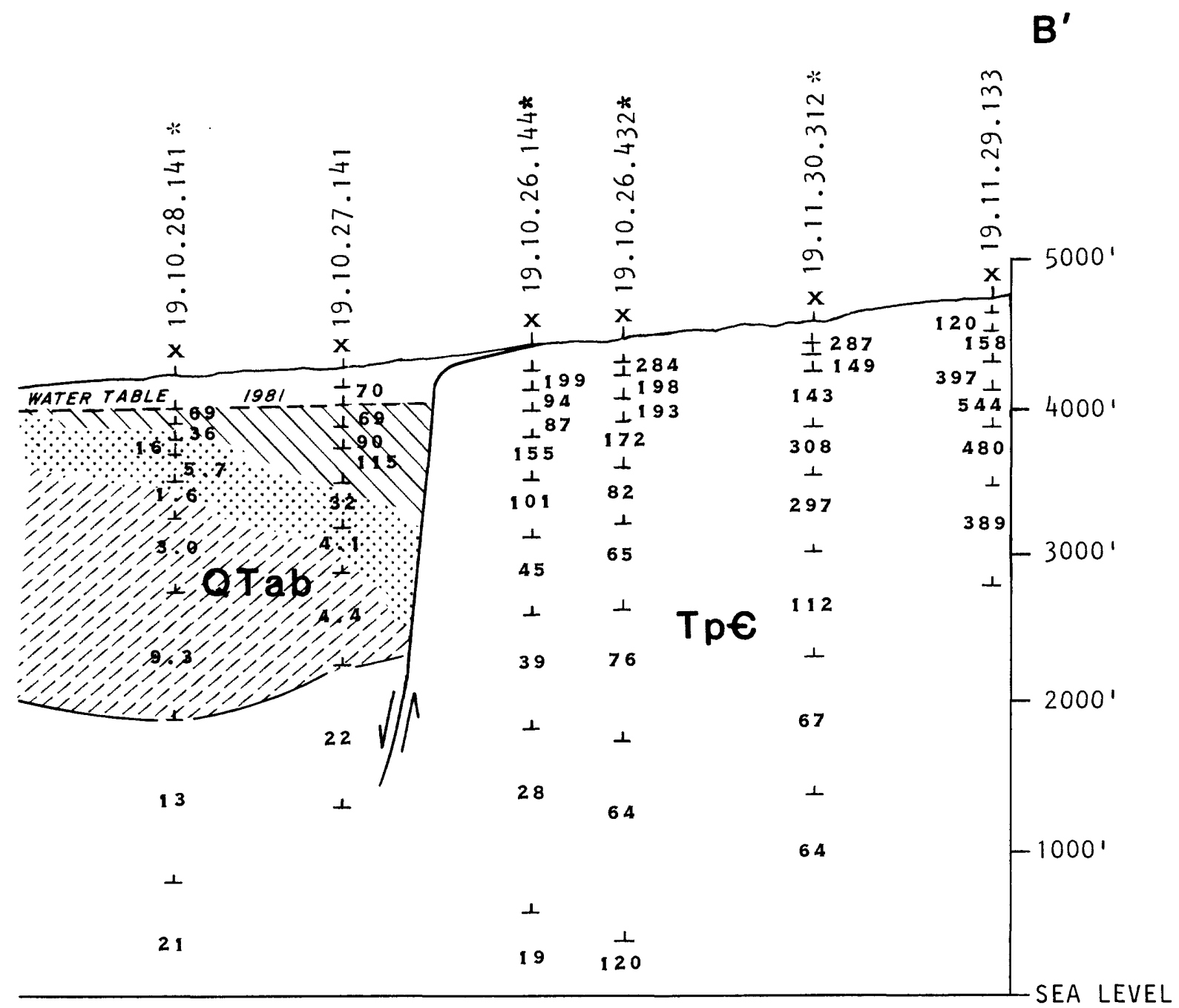




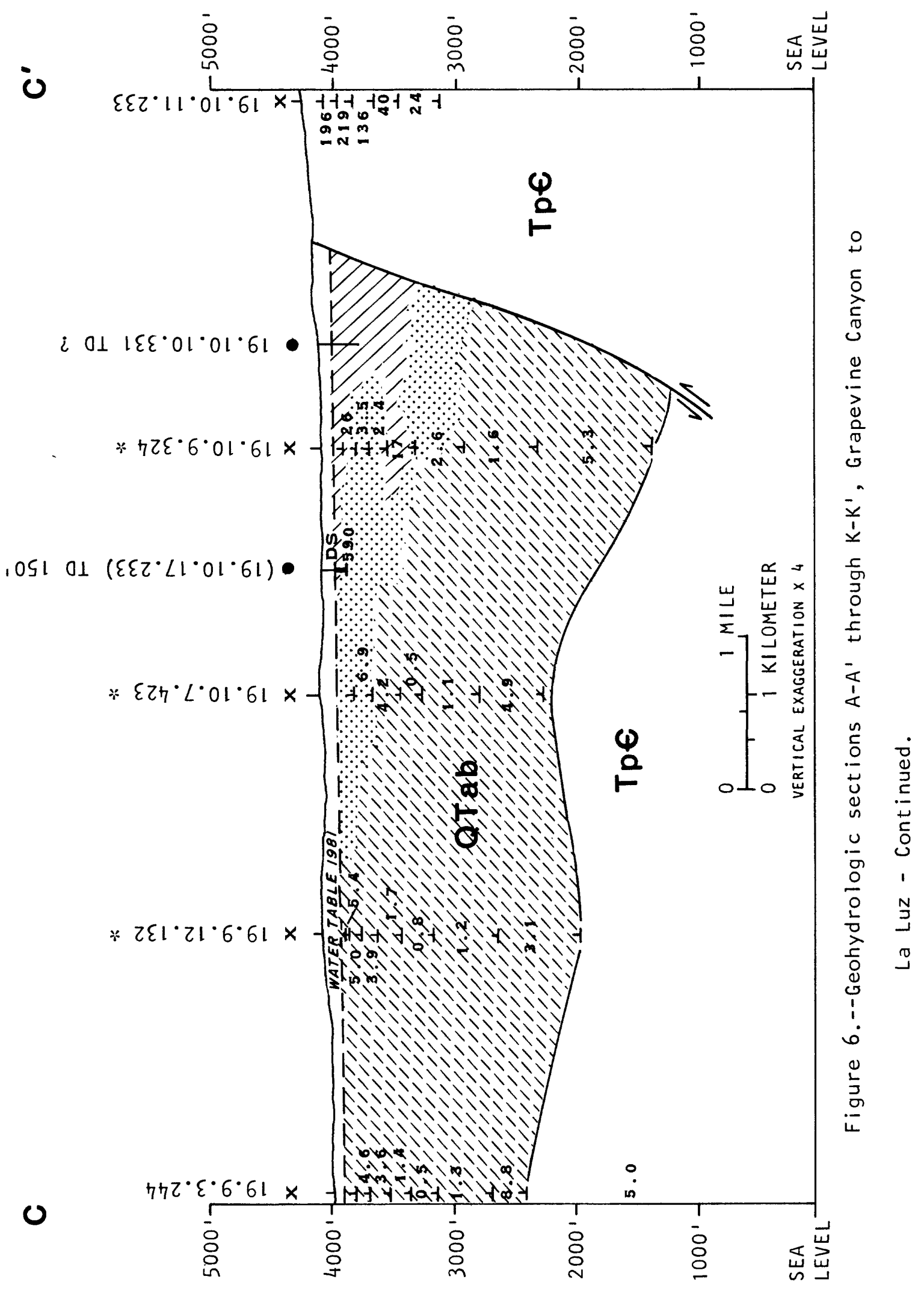




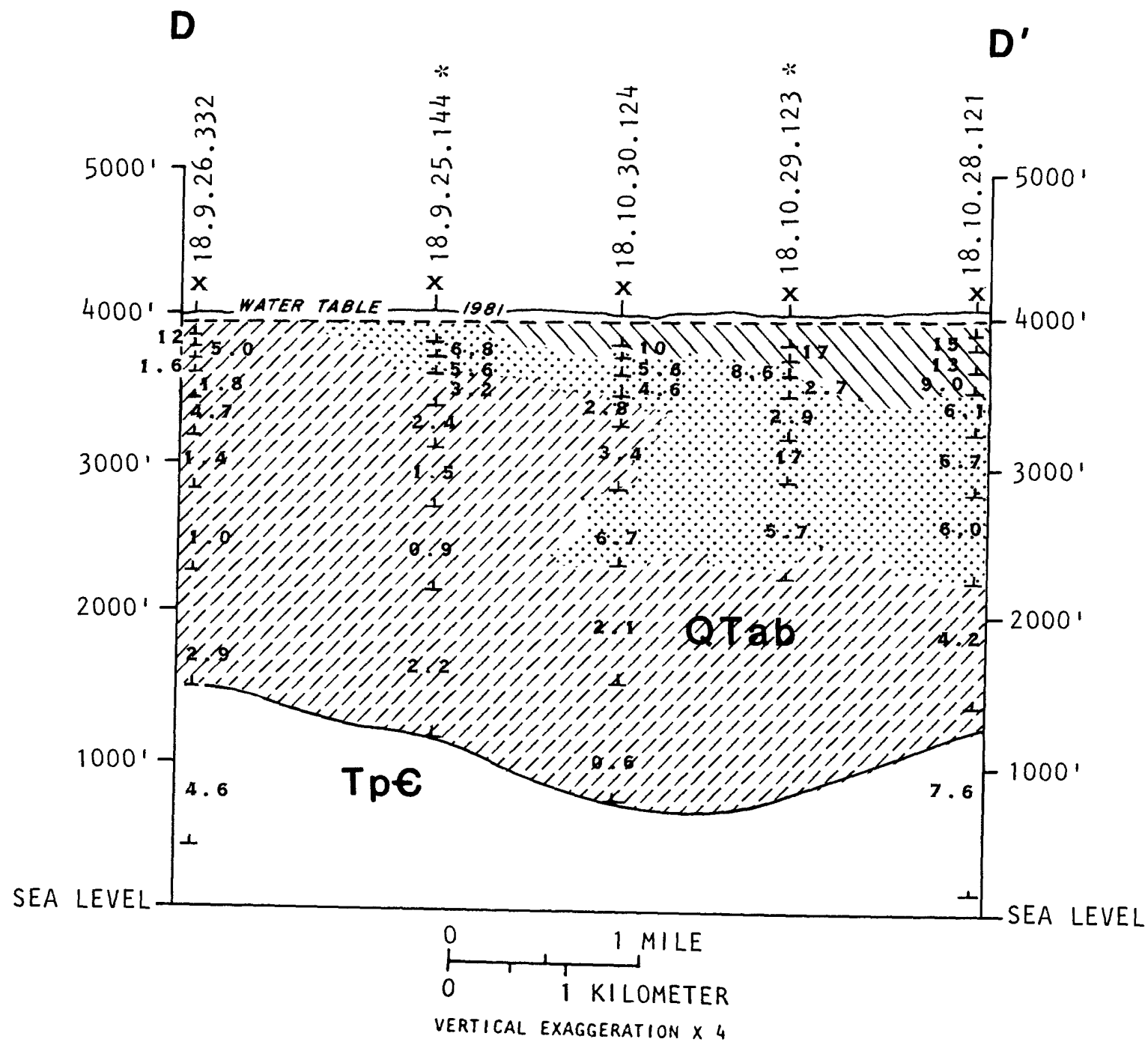

Figure 6.--Geohydrologic sections $A-A^{\prime}$ through $K-K^{\prime}$, Grapevine Canyon to La Luz - Continued. 


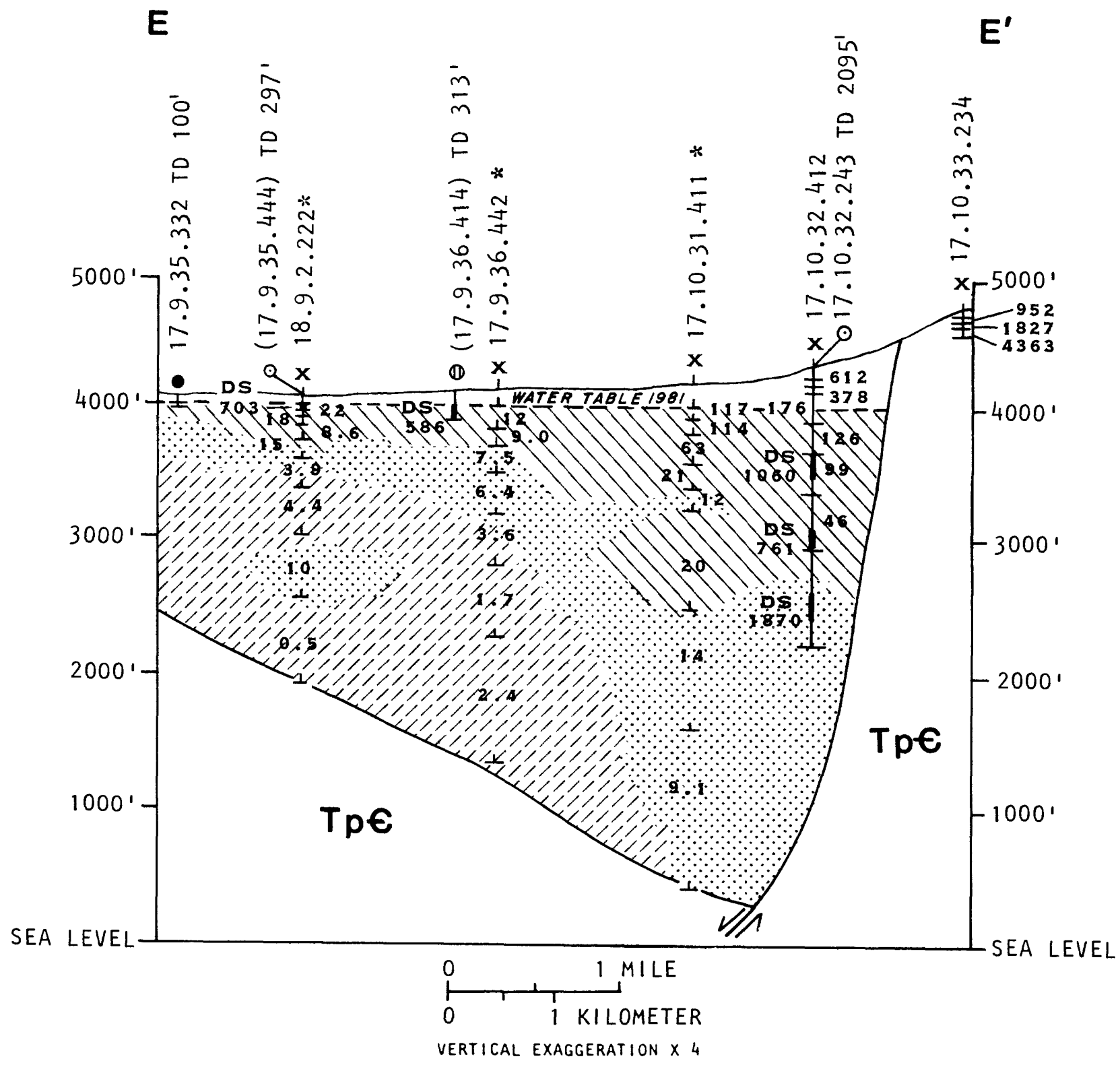

Figure 6.--Geohydrologic sections $A-A^{\prime}$ through $K-K^{\prime}$, Grapevine Canyon to La Luz - Continued. 


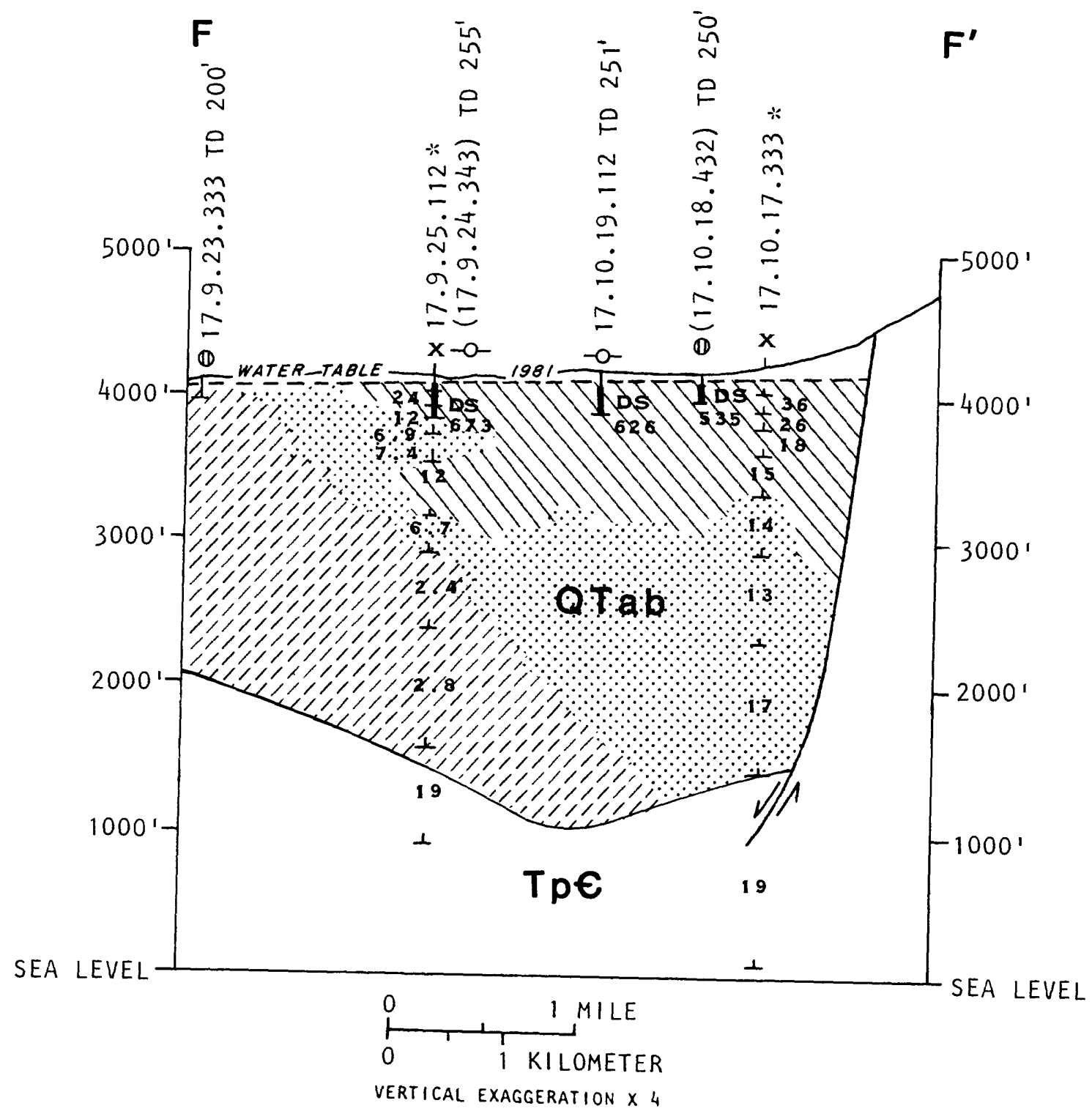

Figure 6.--Geohydrologic sections $A-A^{\prime}$ through $K-K^{\prime}$, Grapevine Canyon to La Luz - Continued. 


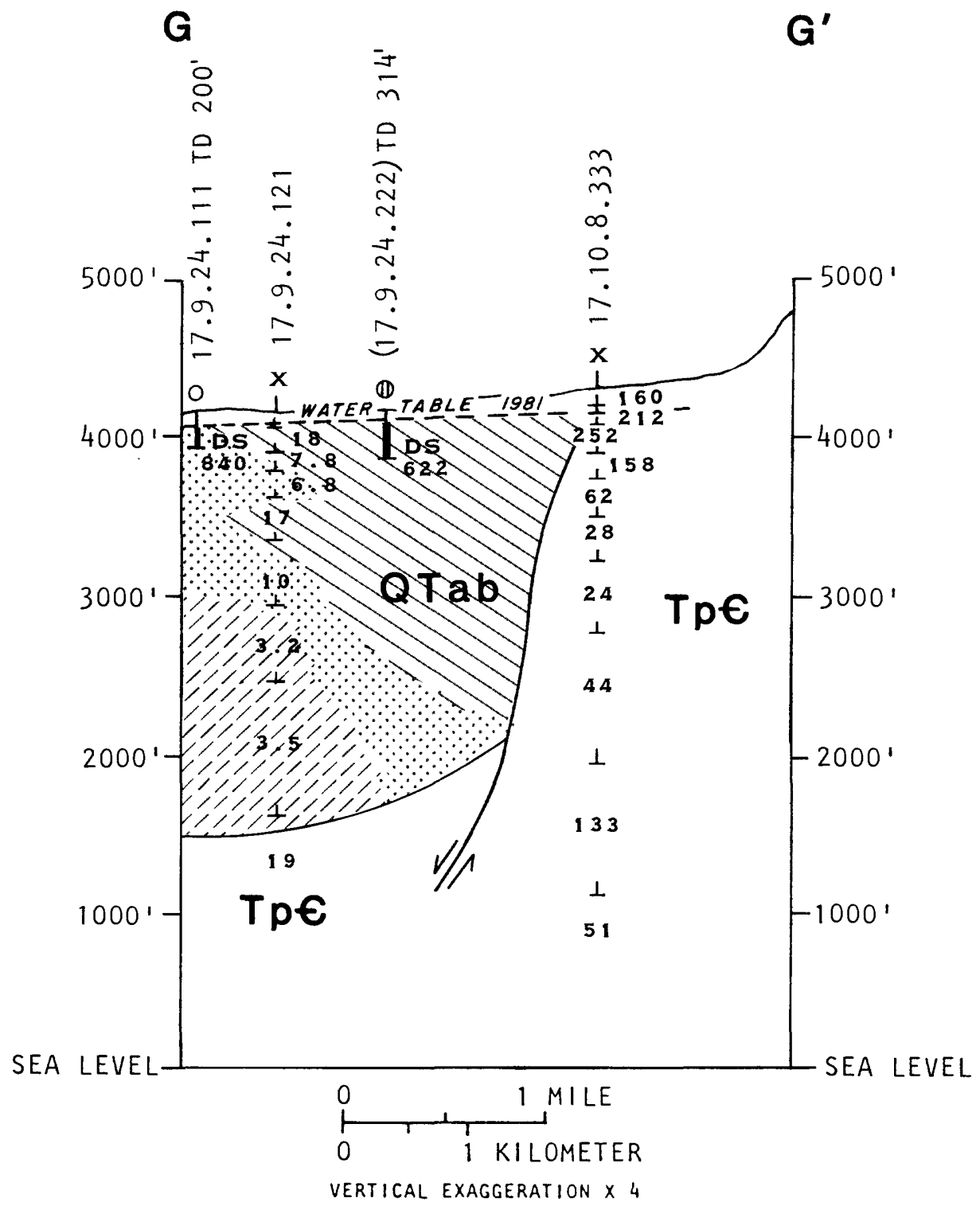

Figure 6.--Geohydrologic sections A-A' through $K-K^{\prime}$, Grapevine Canyon to La Luz - Continued. 


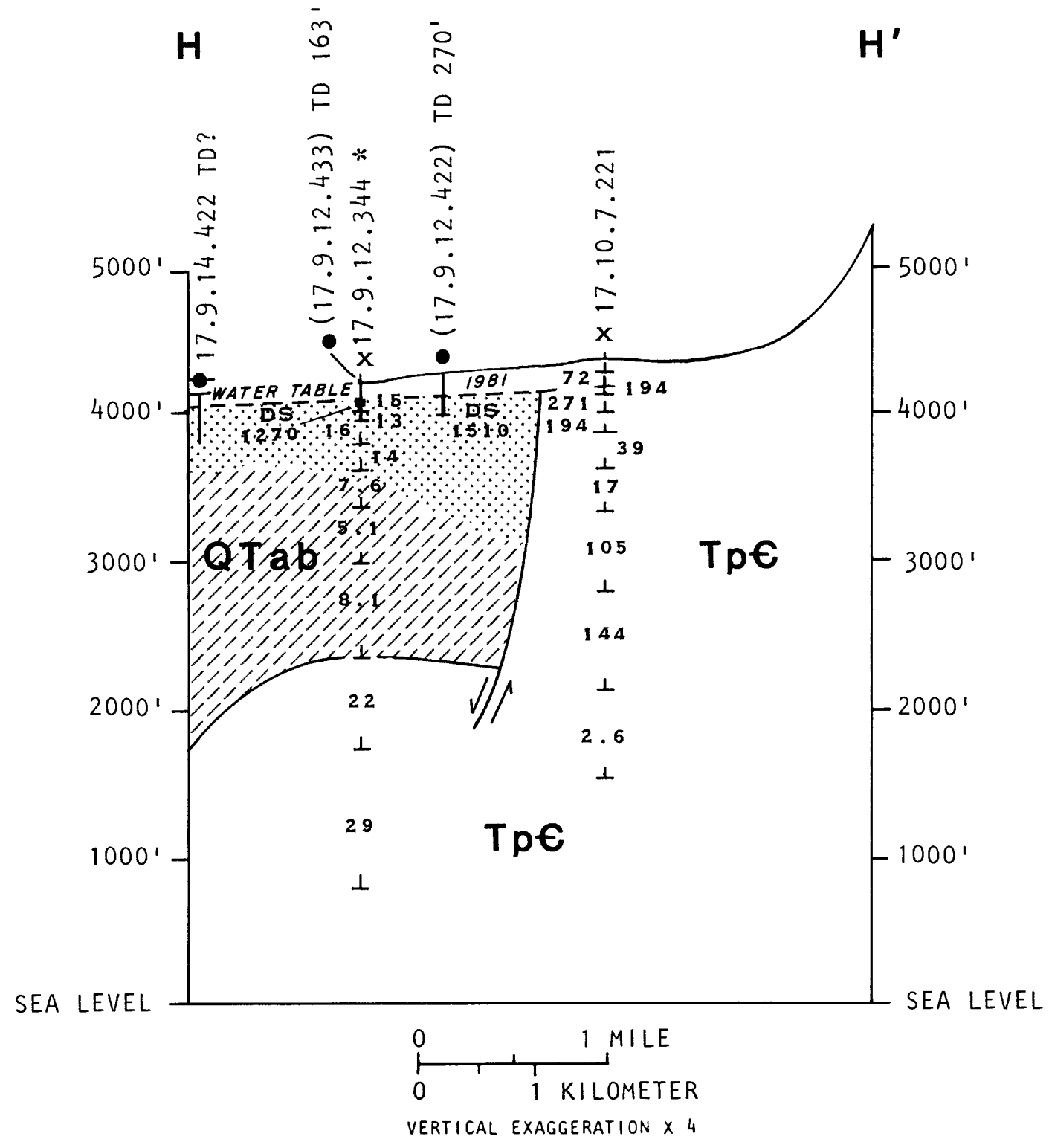

Figure 6.--Geohydrologic sections $A-A^{\prime}$ through $K-K^{\prime}$, Grapevine Canyon to La Luz - Continued. 


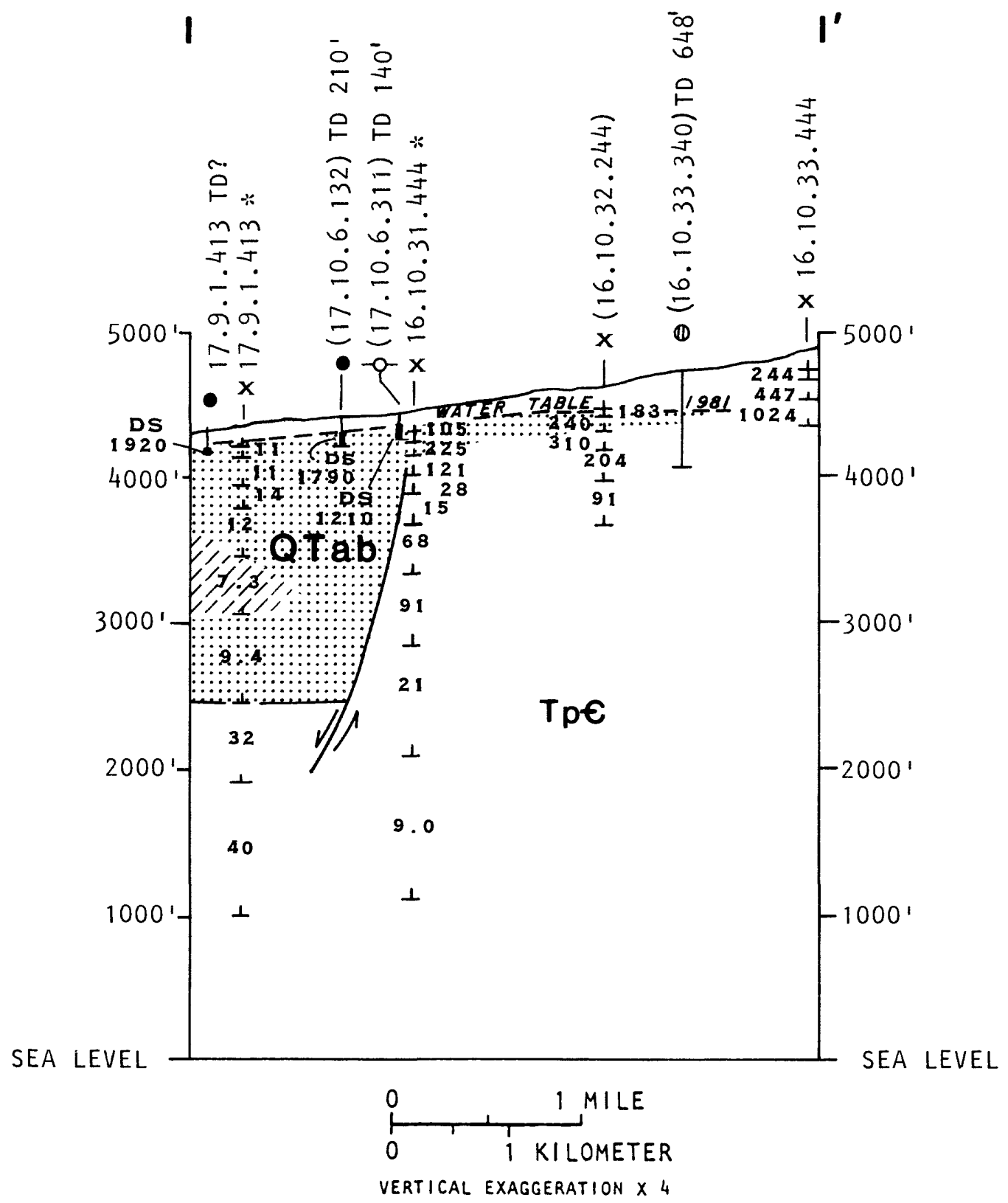

Figure 6.--Geohydrologic sections A-A' through $K-K^{\prime}$, Grapevine Canyon to La Luz - Continued. 


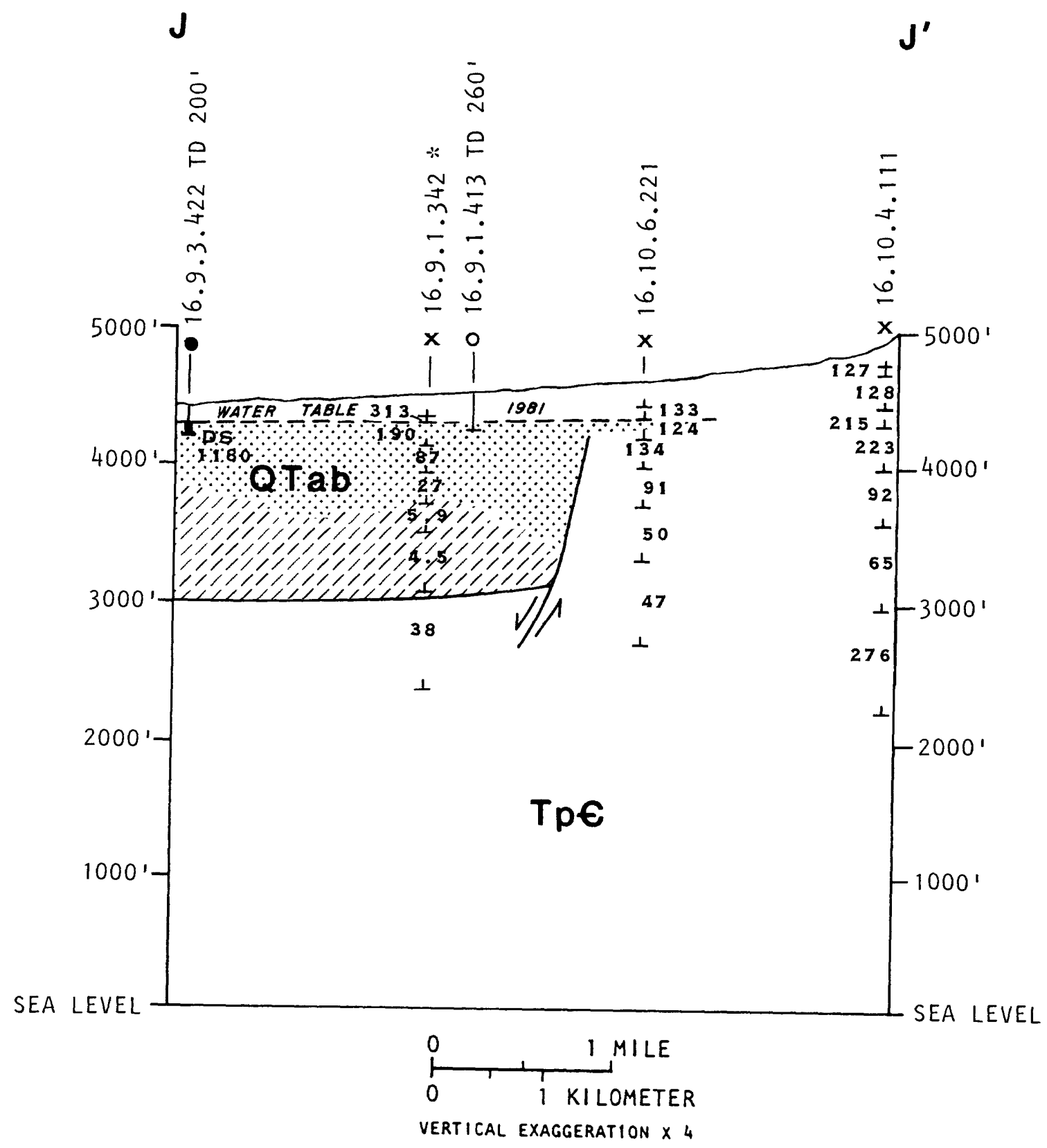

Figure 6.--Geohydrologic sections $A-A^{\prime}$ through $K-K^{\prime}$, Grapevine Canyon to La Luz - Continued. 


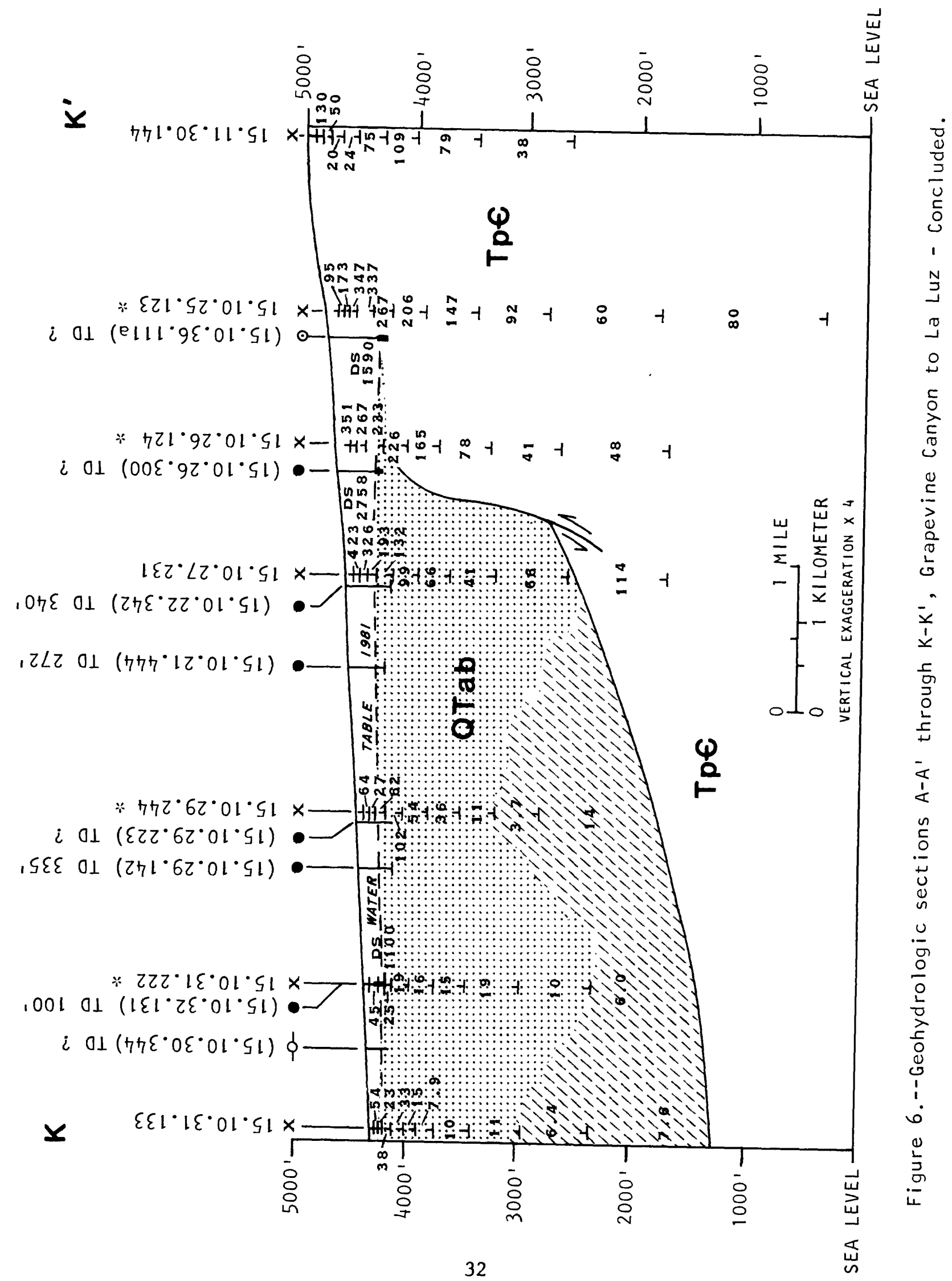


A contour map showing the altitude of the top of consolidated rocks in the area from Grapevine Canyon to La Luz ( $\mathrm{fig}$. 7) was constructed from the hydrologic sections. This map shows the approximate locations of faults as shown in the sections. The altitude of bedrock in this downfaulted area may range from less than 800 feet above sea level south of Alamogordo to as much as 2,800 feet above sea level near the mountain front at La Luz (fig. 7). The gradient of the top of consolidated rock shown by McLean (1970, fig. 7) and exposures of bedrock to the west in the Jarilla Mountains, Tres Hermanos, and small outcrops north of Holloman Air Force Base (fig. 3) indicate that bedrock probably rises gently to the west of the mapped area shown in figure 7 .

The approximate thickness of alluvial-fan deposits in the Grapevine Canyon-La Luz area, as estimated from geohydrologic sections A-A' through $K-K^{\prime}$ (fig. 6), ranges from less than 100 feet on the higher step-faulted blocks adjacent to the Sacramento uplift $\left(K-K^{\prime}\right)$ to about 4,000 feet in the San Andres Canyon area (E-E'). Surficially, these deposits are characterized by very coarse, poorly sorted sediments adjacent to the mountain front and by wellsorted, increasingly fine-grained sediments basinward. Abrupt lithologic changes occur at the surface in places where lenticular beds of gravel and sand grade horizontally to silt and clay.

The abrupt textural changes observed at the surface also occur with depth. Test wells were drilled for Holloman Air Force Base at four locations in fan deposits near Dog Canyon and Escondido Canyon (fig. 5). Boreholegeophysical logs from three of the wells $(18.10 .9 .331,18.10 .16 .444$, and 18.10.34.122) indicate that they penetrated as much as 1,000 feet of thinly interbedded sand and clay units. The three wells reportedly yielded water when tested. The borehole-geophysical logs from the fourth well (18.10.28.210) indicate that this well penetrated only clay and silt to a depth of approximately 1,000 feet. When tested, this well yielded no water.

All of the wells are within 1 mile of the mountain front (fig. 5). The borehole-geophysical logs from these wells demonstrate that abrupt lithologic changes can occur both horizontally and vertically in alluvial-fan deposits near the fan apexes.

The altitudes of water levels in area wells were used to construct a potentiometric-surface map (fig. 8). In several areas, a lack of well data required the use of surface electrical-resistivity measurements to approximate the depth to water. In these areas, contours are dashed to indicate that the water levels are approximately located. Water-level measurements made in 1981 in a number of wells were used to contour many areas. Older water-level measurements were used in several areas because 1981 water-level data were unavailable. The potentiometric surface in these areas also is shown by dashed contours.

The potentiometric-surface map shows ground-water ridges in proximity to the mouths of Grapevine, Alamo, and La Luz Canyons. These ridges indicate that the alluvial-fan sediments probably are being recharged by infiltration of surface flow. The closed depression or cone in the potentiometric surface in the vicinity of the San Andres and Douglass well fields probably is due to the withdrawal of ground water from these well fields. 


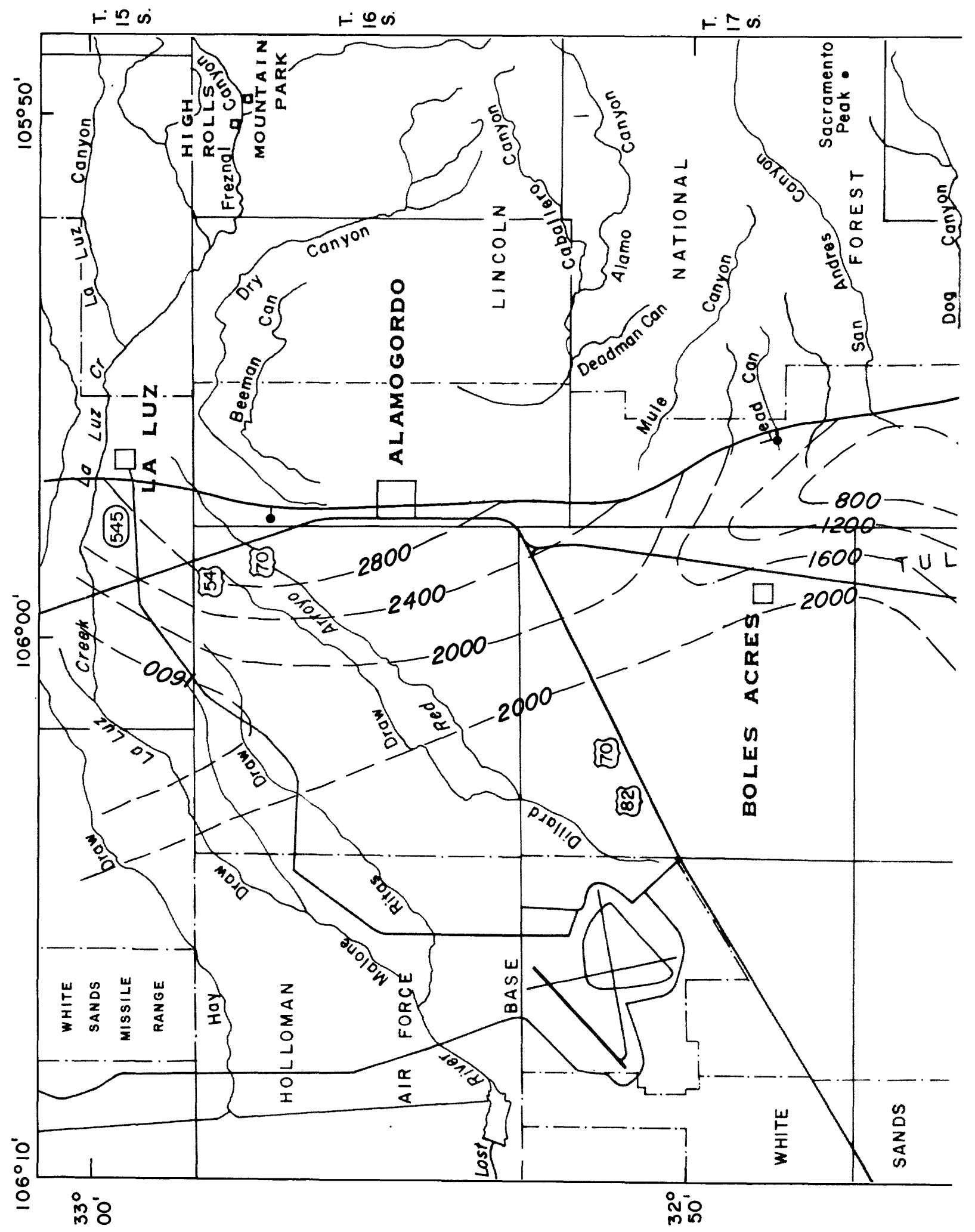




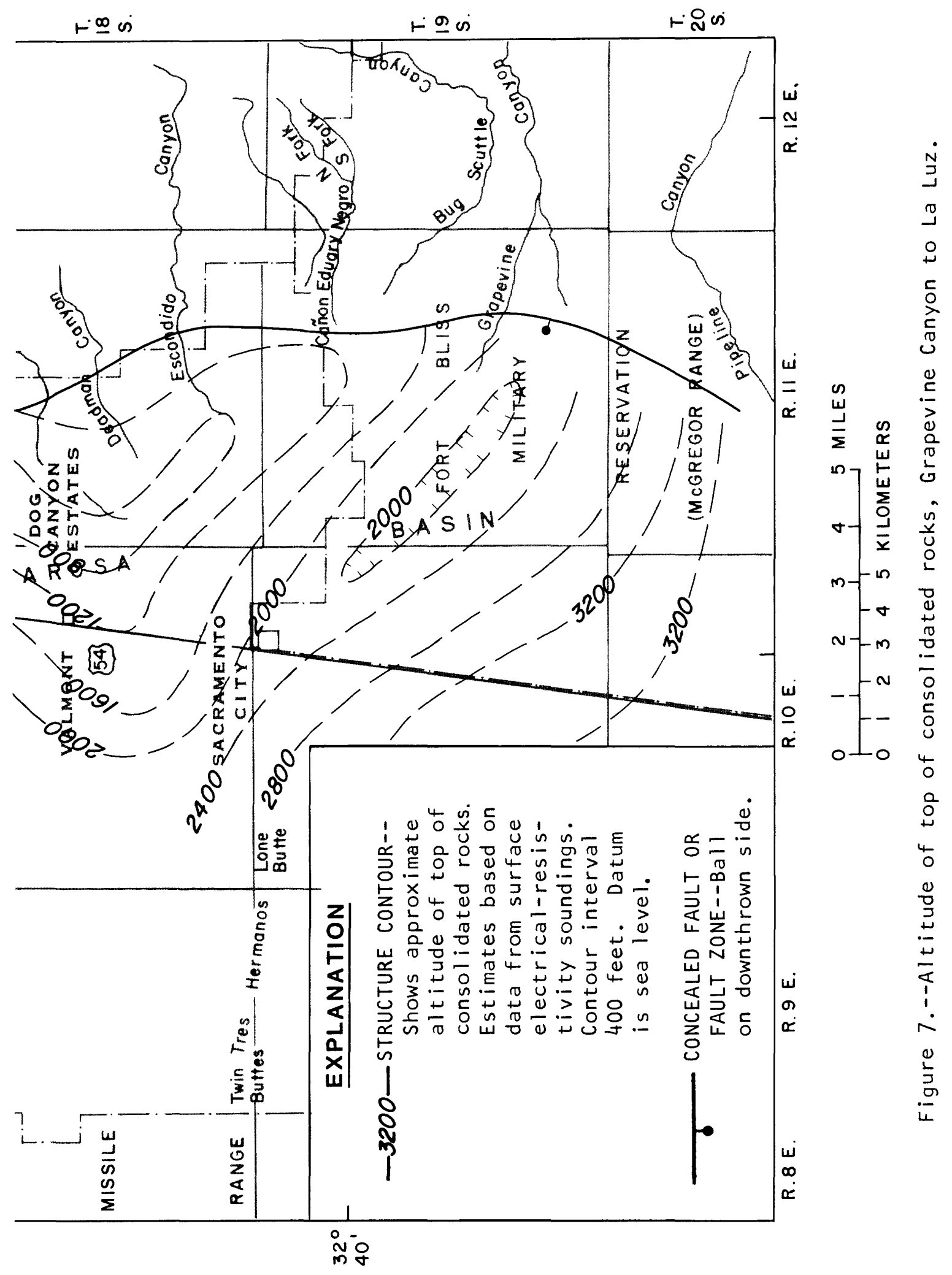




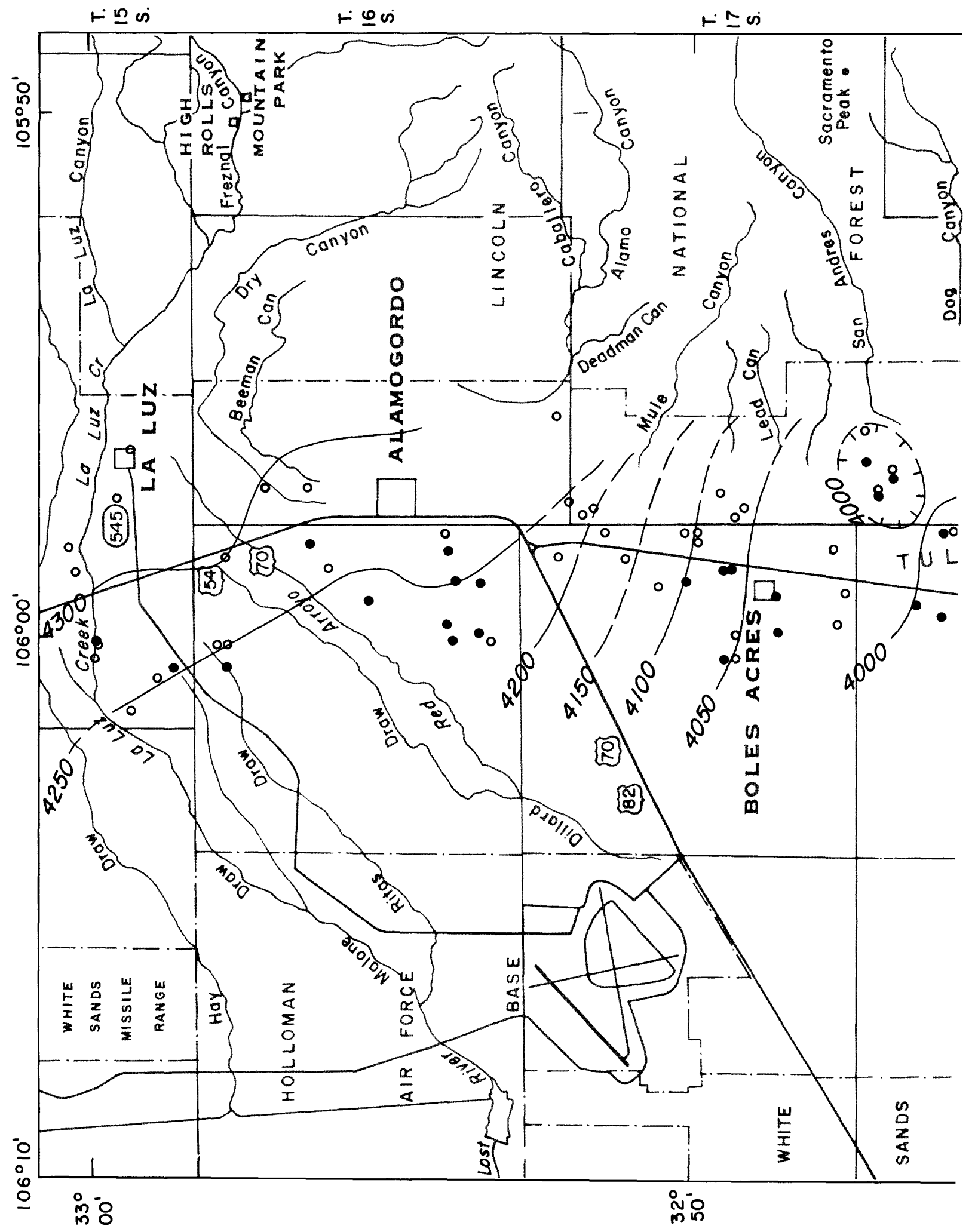




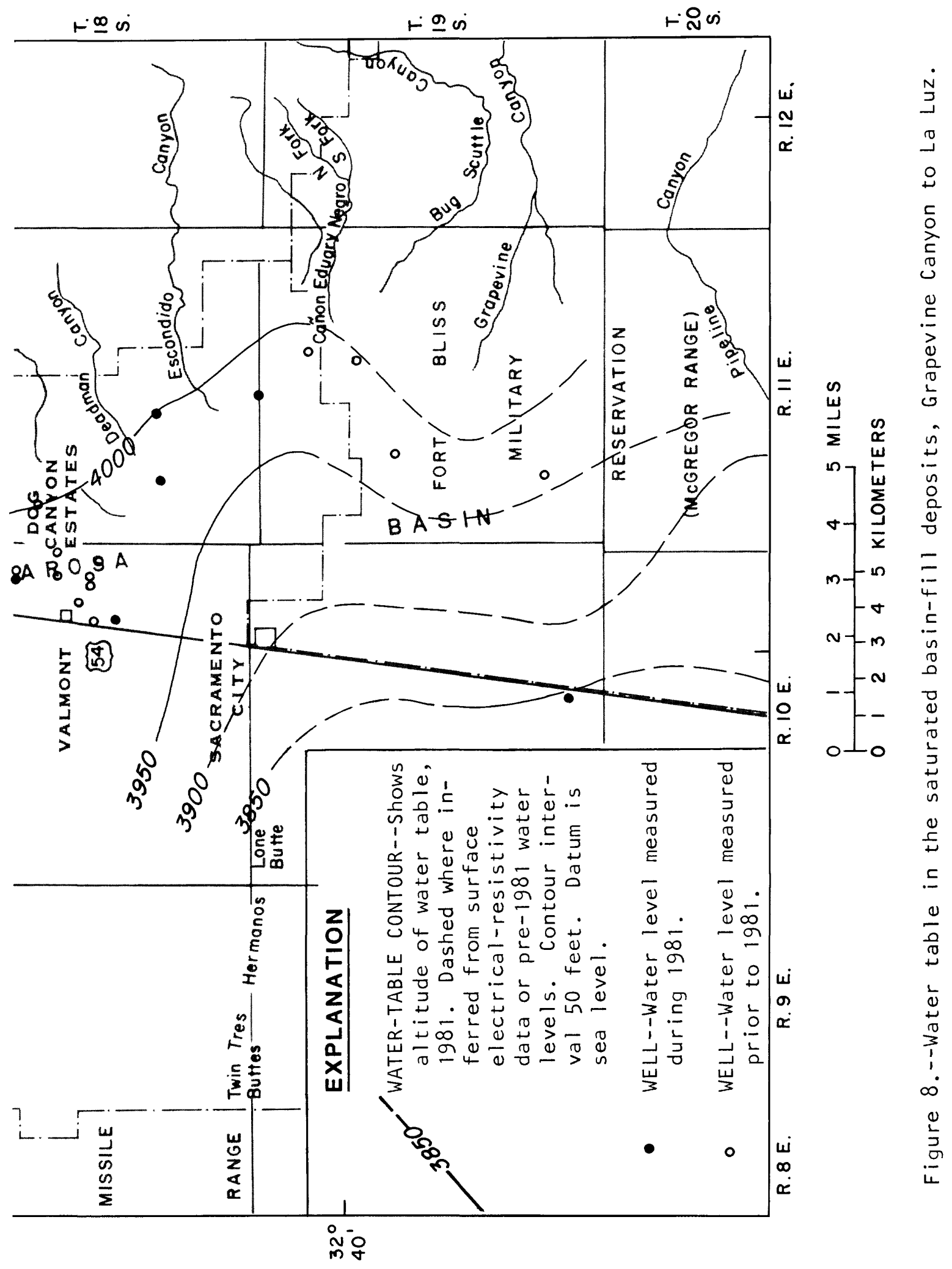


In the Grapevine Canyon area, ground-water flow generally is to the west and southwest at a gradient ranging from about 10 to 50 feet per mile. In the area from Boles Acres to valmont, ground-water flow is to the south at a gradient ranging from 10 to 60 feet per mile. Ground water then flows westward, as indicated by a trough in the potentiometric surface south of Valmont. In the La Luz-Alamogordo area, ground water generally flows to the west and southwest; the gradient ranges from 10 to 40 feet per mile.

The thickness of fan deposits saturated with freshwater (1ess than 1,000 milligrams per liter) was estimated from geohydrologic sections to construct a saturated-thickness map (fig. 9). Sediments saturated with freshwater are located along the Sacramento Mountains from the Grapevine Canyon area to approximately 3 miles south of Alamogordo and east of Highway 54. The freshwater zone ranges in thickness from a feather edge to as much as 1,400 feet. Saturated sediments include poorly sorted boulders, sand, and silt near fan apexes and silt and clay near the base of the fans. Estimated specific yields of these sediments range from 8 to 12 percent (McLean, 1970, p. 20; Garza and McLean, 1977 , p. 38).

From the freshwater saturated-thickness map (fig. 9), an estimated 17.4 million acre-feet of alluvial-fan sediments may contain freshwater in the area from Grapevine Canyon to approximately 3 miles south of Alamogordo. If McLean's estimates of the specific yield of these sediments are used, the volume of freshwater in storage may be between 1.4 and 2.1 million acre-feet, not all of which is recoverable. Because minimal water-chemistry data are available for greater depths, estimation of the approximate boundary between the freshwater and underlying slightly saline water zones depends primarily upon surface electrical-resistivity data. Deep test wells are needed to better determine the thickness of the freshwater zone on the eastern side of the Tularosa Basin. A continuing program of monitoring ground-water levels and pumpage, particularly in areas of significant ground-water development, will allow a better definition of the specific yield of alluvial-fan deposits on the eastern side of the Tularosa Basin.

Ground water containing dissolved-solids concentrations between 1,000 and 3,000 milligrams per liter is present beneath and adjacent to freshwater resources in the Tularosa Basin. A map showing the probable thickness of the slightly saline zone from Grapevine Canyon to the village of La Luz (fig. 10) was constructed from the geohydrologic sections (fig. 6) and from available water-chemistry data. The slightly saline zone may range in thickness from a westward feather edge to more than 2,000 feet.

The volume of sediments saturated with slightly saline water is estimated from the thickness map to be approximately 45 million acre-feet. Based on an estimated specific yield of 8 to 12 percent for the Holloman well fields, the estimated volume of slightly saline water in storage in the area from Grapevine Canyon to La Luz may be between 3.6 and 5.4 million acre-feet, not all of which is recoverable. Maps of the thickness of the slightly saline water zone (McLean, 1970, fig. 8) indicate that an additional 14 to 21 million acre-feet of slightly saline water may be in storage in the Tularosa and Three Rivers areas. 
Ground water in the alluvial fans on the eastern side of the Tularosa Basin is characterized by a northward increase in dissolved solids along the mountain front. Ground water containing dissolved-solids concentrations of less than 1,000 milligrams per liter is present from the Grapevine Canyon area to approximately 3 miles south of Alamogordo; from this point northward, ground water is classified as slightly saline to saline.

Piper trilinear diagrams (fig. 11) were constructed using water-chemistry data from wells completed in alluvial fans in four areas on the eastern side of the Tularosa Basin to define water-chemistry changes that may reflect different lithologies of contributing surface-water drainages in the Sacramento Mountains and of alluvial-fan deposits derived from these drainages. These areas are from Grapevine Canyon to Dog Canyon (fig. 11, area A), from Dog Canyon to La Luz (area B), from La Luz to halfway between Tularosa and Three Rivers (area C), and from halfway between Tularosa and Three Rivers to Oscura (area D). Because the concentration of dissolved solids in water in these alluvial-fan deposits generally increases with depth, most wells have been constructed to obtain water from shallower zones. Trilinear plots reflect the water chemistry of these zones.

In the area from Grapevine Canyon to Dog Canyon, predominant cations in ground water are calcium, magnesium, and, less frequently, sodium (fig. 11, area A). Sulfate and bicarbonate are predominant anions. Drainage areas in the Sacramento Mountains that contribute runoff for recharge in this area include outcrops of limestone, dolomite, and gypsum. Alluvial fans also consist of detritus from these outcrops. Soluble carbonate and evaporite minerals present in outcrop areas and in fan material possibly provide a source for calcium, magnesium, sulfate, and bicarbonate ions to water. Sodium, when associated with sulfate and bicarbonate, probably is in solution as a result of cation exchange that may occur as ground water comes into contact with finer grained alluvial sediments.

Predominant cations present in ground water in the area from Dog Canyon to La Luz (fig. 11, area B) include calcium, magnesium, and sodium. Sulfate, bicarbonate, and chloride are predominant anions. Drainage areas that provide water for recharge to fan aquifers in this area include larger drainages where outcrops containing soluble gypsum and salt are present, and smaller drainages that consist chiefly of limestone and dolomite. The transition from water enriched in calcium, magnesium, sulfate, and bicarbonate to sodium and chloride may indicate the mixing of water recharged from different drainages or the process of ion exchange within the aquifer.

Ground water in the area from La Luz to oscura (fig. 11, areas C and D) is enriched in calcium and, less commonly, sodium. Sulfate is the predominant anion. Outcrops in drainage areas consist largely of Permian-age gypsumbearing rocks. As water passes over outcrops and then through fan deposits that consist of detritus from these rocks, calcium and sulfate are dissolved. 


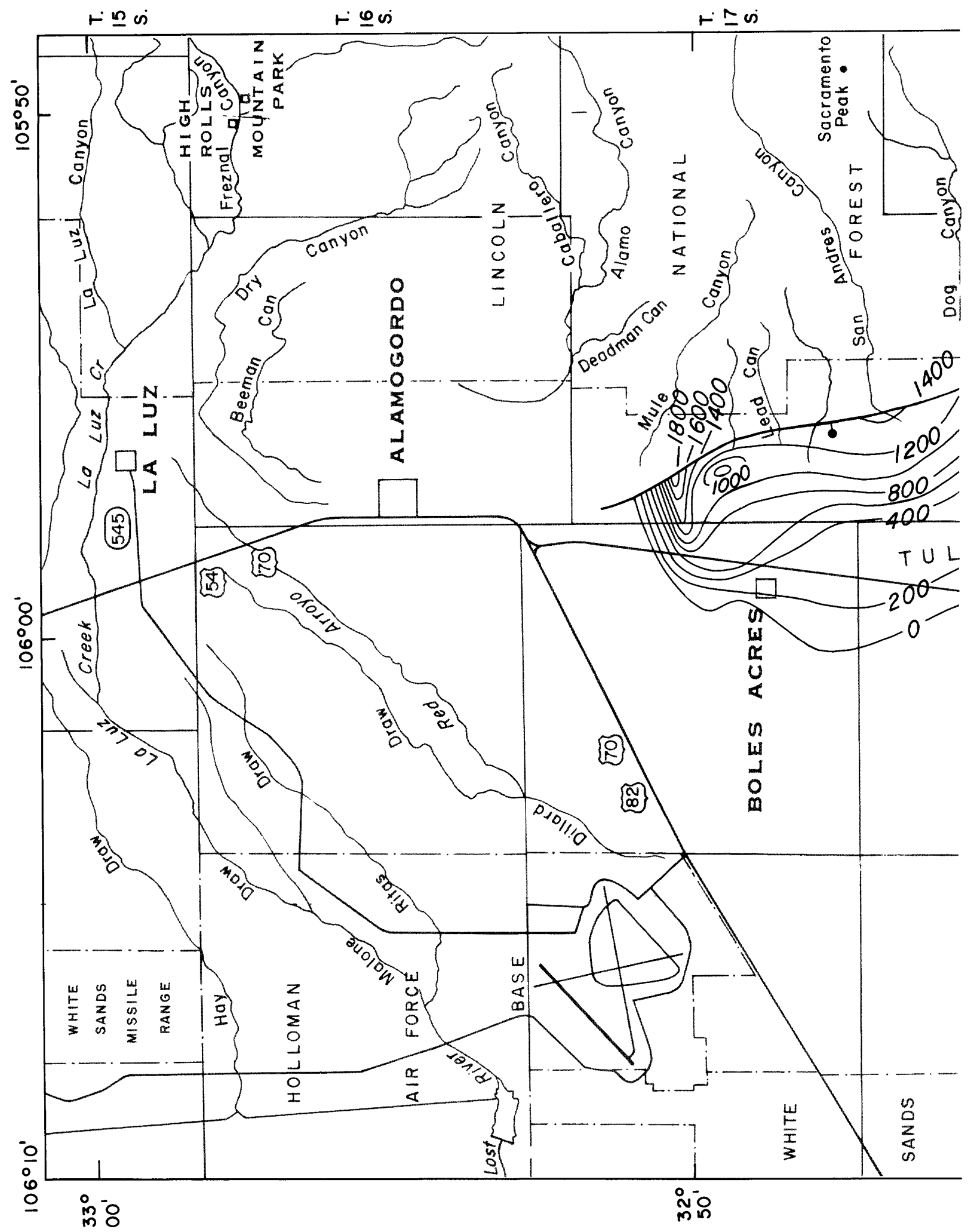




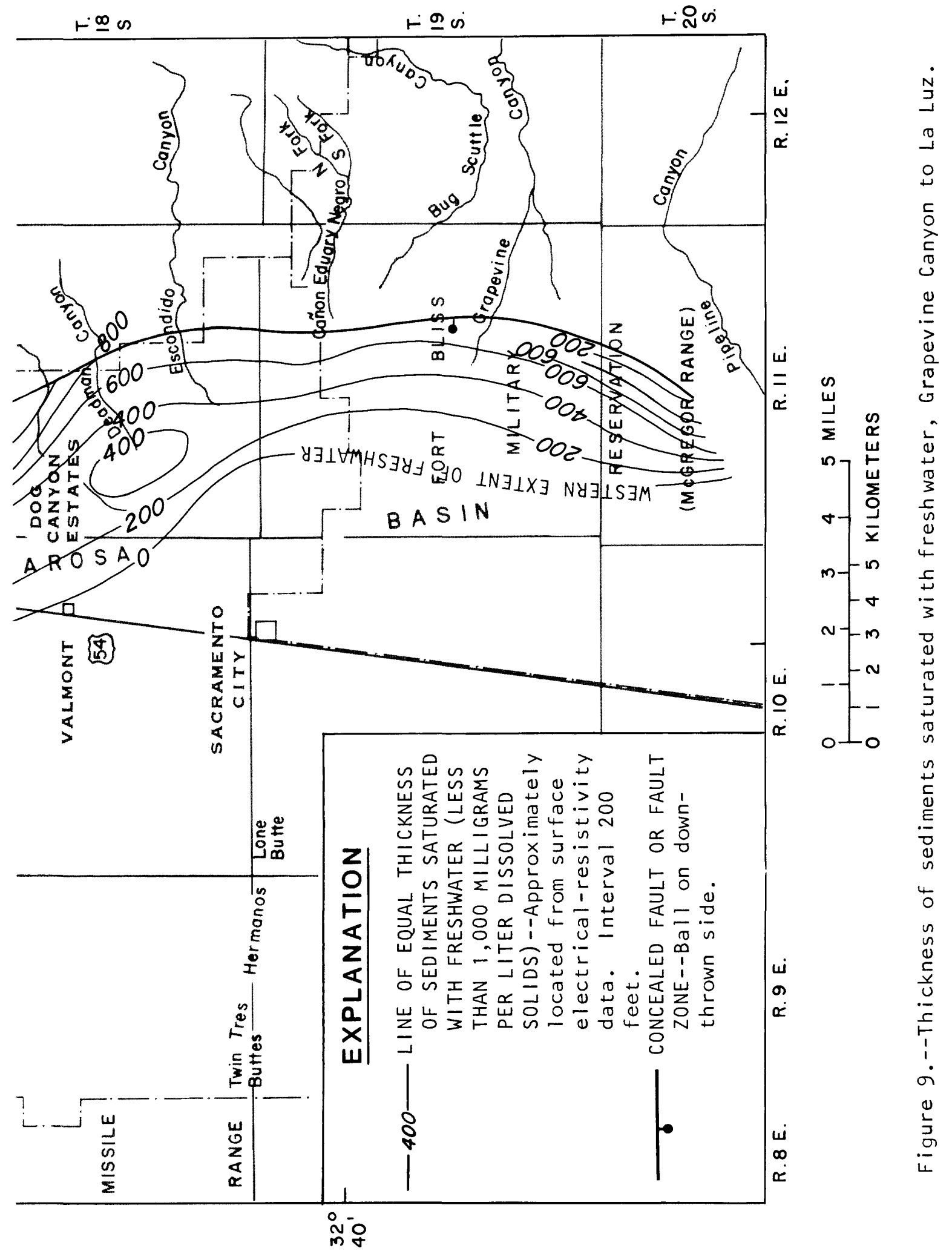




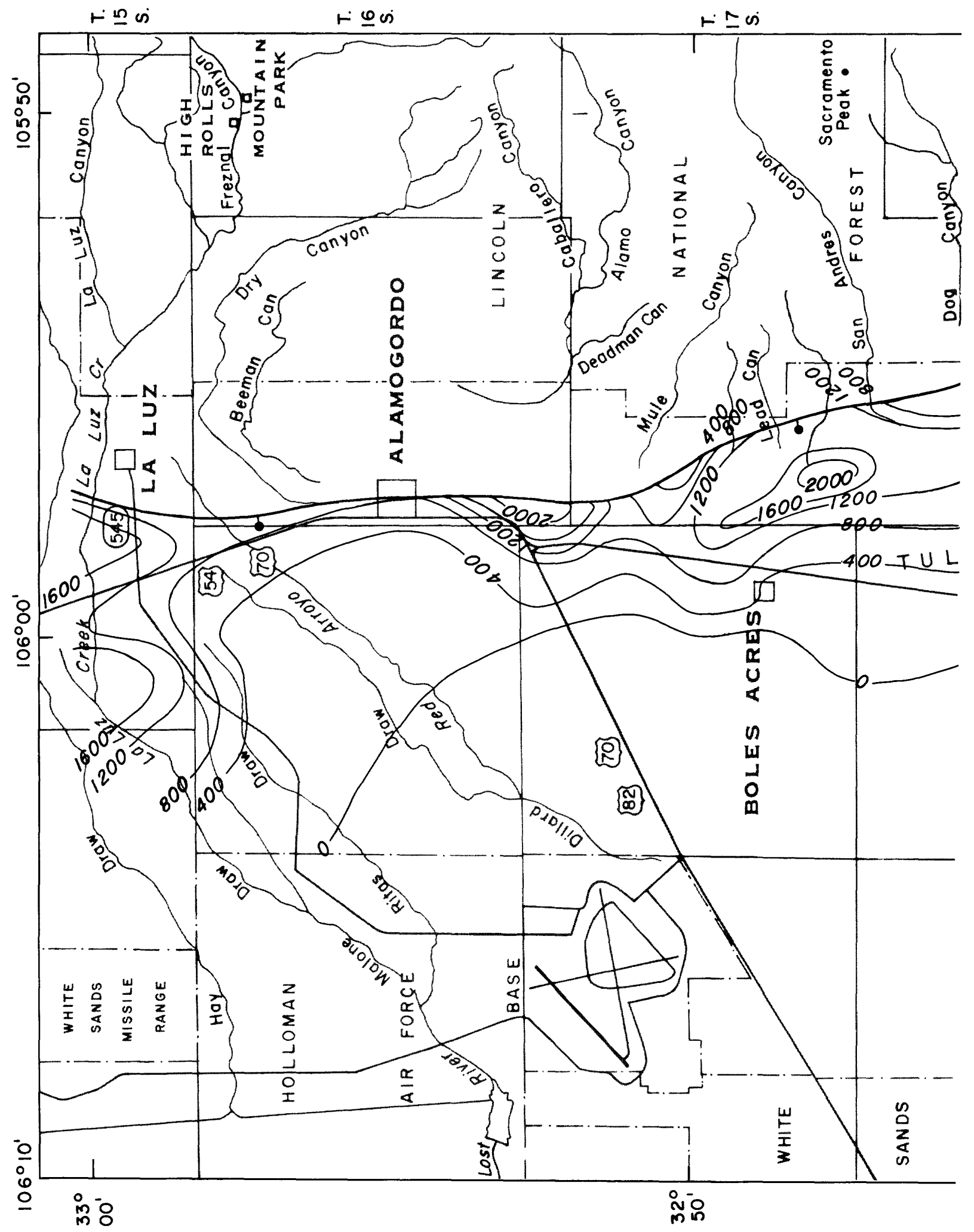




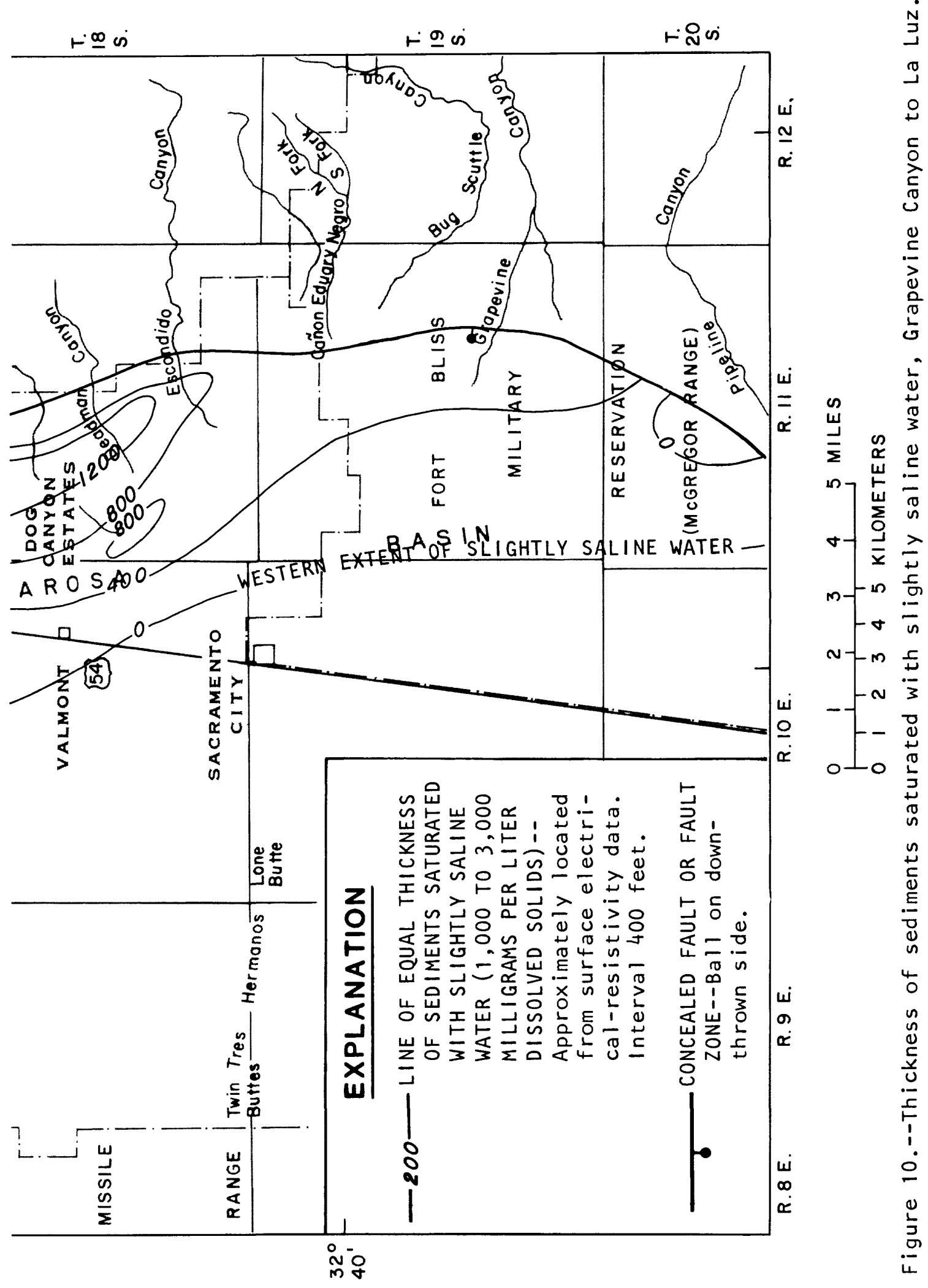




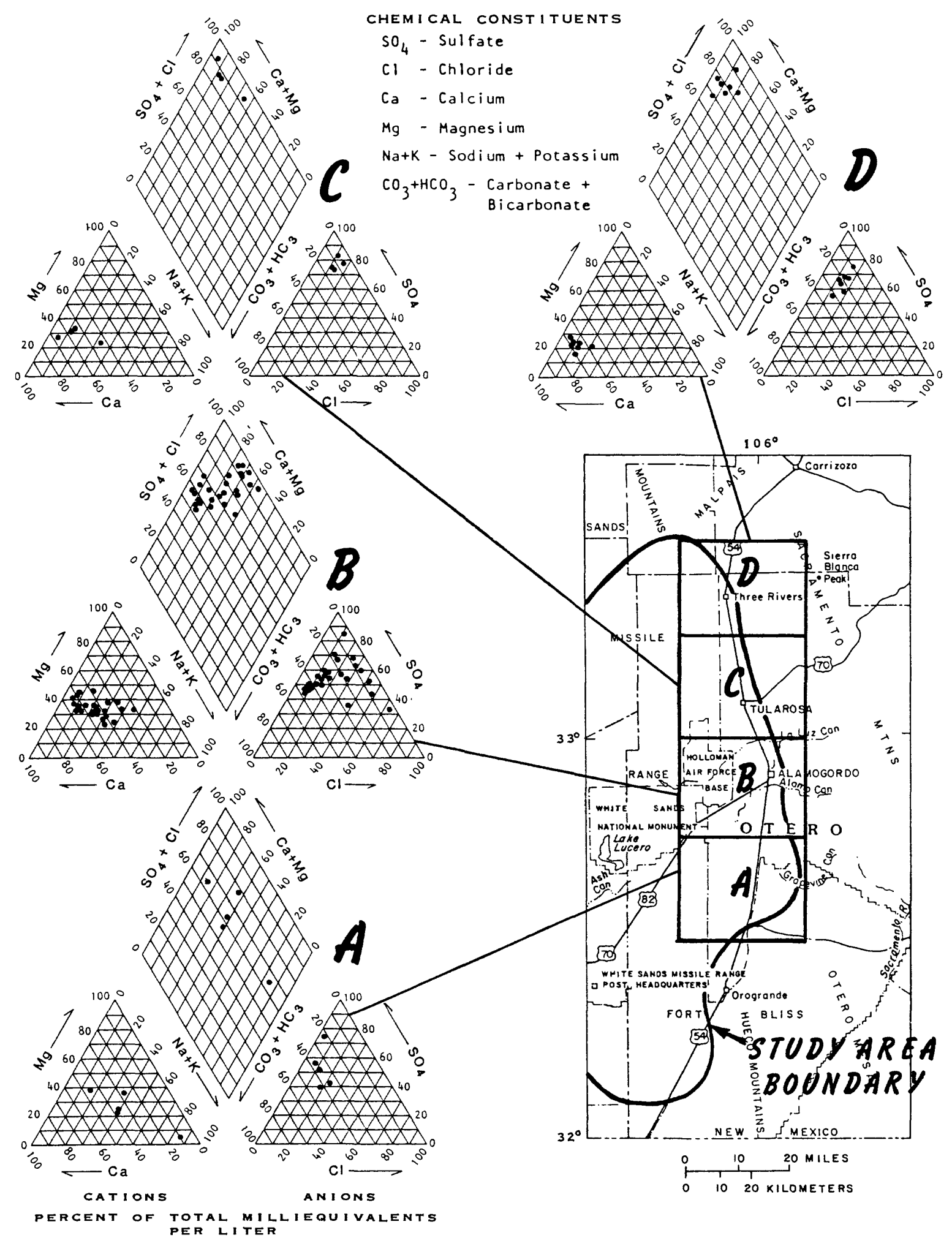

Figure 11.--Chemical composition of ground water, eastern side of the Tularosa Basin. 
Drainage areas contributing water to the northeastern part of the basin are more extensive and better developed than those to the south. Very soluble sodium chloride, present in Permian rocks to the north, may have been leached out earlier in drainage development. Less soluble gypsum present in these rocks is now being weathered, providing a ready source for calcium and sulfate as water moves across these drainage areas. Increased concentrations of dissolved solids in ground water for areas to the north, compared to areas to the south, may be a function of the size of these drainage areas and the abundance of evaporite minerals present in outcrops to the north. Smaller, less developed drainages to the south are cut into a thick section of carbonate rocks that contain less abundant supplies of soluble minerals. Smaller concentrations of dissolved solids in ground water are typical in these areas.

\section{Western Side of the Tularosa Basin}

Landsat imagery and the absence of springs on the western side of the basin indicate that ground-water discharge to the surface probably is smaller than on the eastern side. This smaller amount of discharge could be attributed to smaller drainage areas in the San Andres Mountains or to the presence of a thick caliche layer over alluvial fans in this area that inhibits recharge. Much of the precipitation runoff on the eastern side of the San Andres Mountains probably reaches the playa areas on the western side of the basin without significant recharge to alluvial fans. To the south, ground-water discharge from alluvial-fan deposits may occur as flow to central-basin fluvial-eolian deposits.

\section{Rhodes Canyon alluvial fans}

Fresh and slightly saline ground water possibly may be present in the coalescing alluvial fans deposited on the west side of the Tularosa Basin in the vicinity of Rhodes Canyon (fig. 1). The moderately large areas in the San Andres Mountains drained by Rhodes Canyon and associated intermittent tributaries (exceeding 50 square miles) could provide a source of water for recharge to freshwater and slightly saline water zones in these alluvial fans. Because few wells have been drilled in alluvial fans of the Rhodes Canyon area, 17 surface electrical-resistivity soundings were conducted (fig. 12) to provide a better understanding of the extent and availability of the fresh and slightly saline ground-water resources.

Three geohydrologic sections (fig. 13) were constructed from surface electrical-resistivity sounding data and available well information. Freshwater and slightly saline water zones on these sections are characterized by larger resistivity values than generally observed in the Grapevine-La Luz area. These values may be affected in part by the large resistivity of coarse-grained sediments, consisting of gravel and cobbles, typical of nearsource pediment deposits. These coarse sediments occur at the surface and at depth across much of the upper part of alluvial fans in the Rhodes Canyon area. A thick caliche zone toward the apex of the alluvial fans may contribute to the large observed resistivity values. 
Three wells ( $\mathrm{RC}-1, \mathrm{RC}-2$, and $\mathrm{RC}-3$ ) were drilled in the Rhodes Canyon area (fig. 12) for which hydrologic information, including geophysical and lithologic logs, water levels, and water-chemistry analyses, is available. Well RC-1 (12.5.31.434) was drilled in 1965 to a total depth of 940 feet. According to the sample-description $\log$ (Doty, 1968f, p. 46-47), alluvial sediments penetrated by this well consist of poorly sorted gravel, sand, and silt. During a bailing test, this well yielded less than 3 gallons per minute of freshwater with a dissolved-solids concentration of 618 milligrams per liter (Doty, 1968f, p. 50-51).

Poorly sorted sediments also were penetrated in well RC-2 (12.5.28.432). This well, drilled in 1964 to a depth of 358 feet, was abandoned without any development or production test because it produced saline water with a dissolved-solids concentration of 3,290 milligrams per liter.

We11 RC-3 (13.5.27.421) was drilled in 1969 to a depth of 750 feet. Only a few thin sand beds were penetrated in the predominantly clay lithology, and the reported maximum yield from these sand beds was about 10 gallons per minute (Lyford, 1970, p. 44). Water samples from different depths contained large concentrations of dissolved solids, ranging from 27,100 to 177,000 milligrams per liter. Predominant ions were sodium and chloride.

A water-table map was constructed from water levels measured in the Rhodes Canyon wells ( $\mathrm{fig}$. 12). Contours were dashed because of the limited amount of available water-level data. These contours indicate that flow is to the east and southeast at an average hydraulic gradient of about 25 feet per mile. Contours could represent water levels of a series of perched water zones related to step-faulted bedrock along the basin margin.

According to the geohydrologic sections, the freshwater zone could be as much as 1,500 feet thick in places, thinning basinward to a feather edge. Based on limited borehole data, sediments saturated with freshwater and slightly saline water may be characterized in most places by poor sorting and small hydraulic conductivity. Additional test wells would be needed to adequately define the extent and availability of fresh and slightly saline ground-water supplies in the Rhodes Canyon area. 


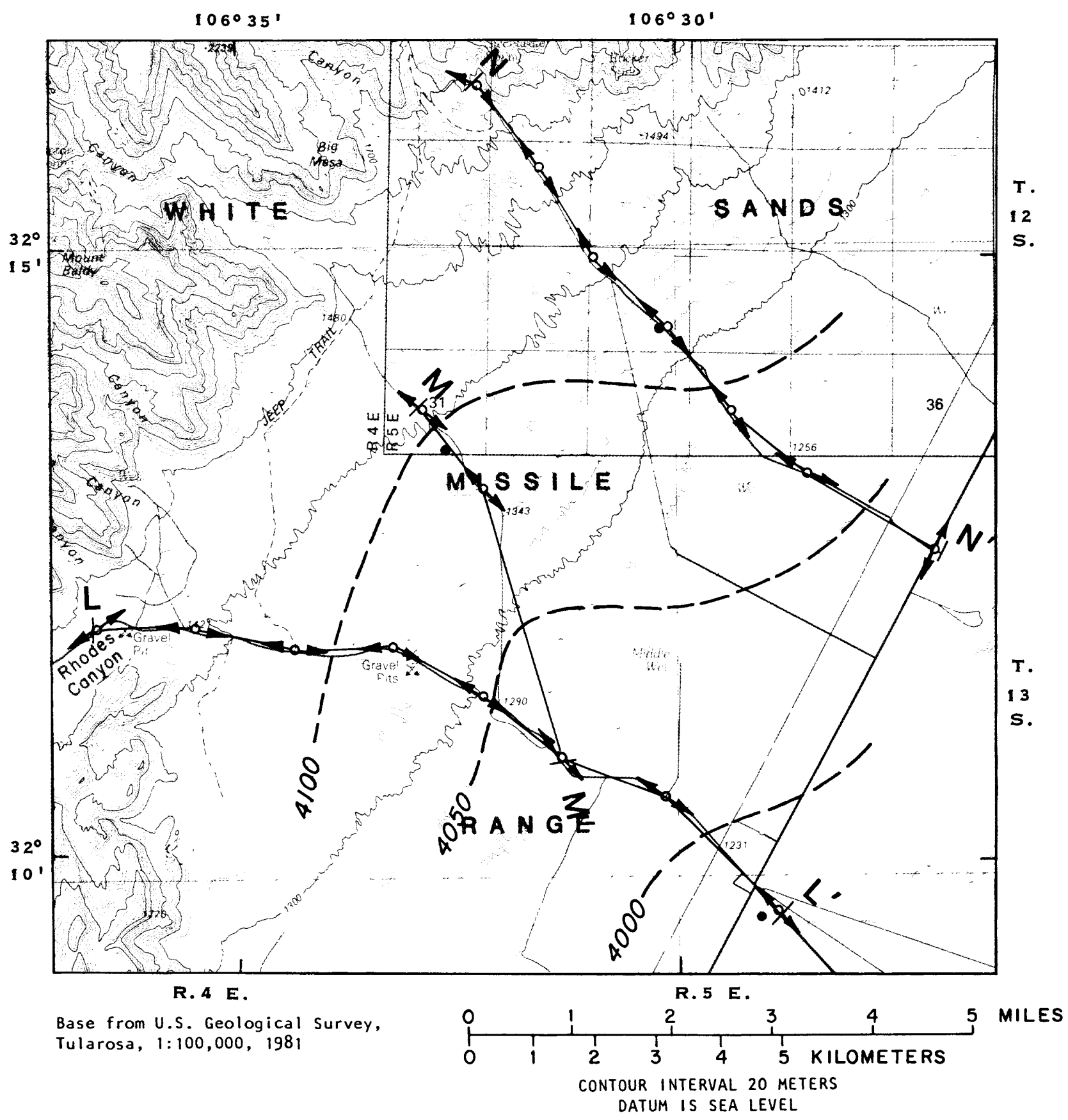

\section{EXPLANATION}

- -4000- - INFERRED WATER-TABLE CONTOUR--Shows altitude of water table, 1981, based on limited data collected from 1964 to 1981 or from surfaceresistivity data. Contour interval 50 feet. Datum is sea level.

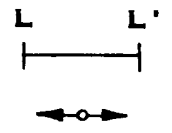
GEOHYDROLOGIC SECTION SURFACE ELECTRICAL-RESISTIVITY SOUNDING SITE (1981)-Arrows indicate direction of sounding layout.

- TEst Well

Figure 12.--Water table in the saturated basin-fill deposits of the Rhodes Canyon alluvial fans, White Sands Missile Range. 


\section{EXPLANATION}

\section{GEOLOGIC DATA}

QTab BOLSON DEPOSITS--Pleistocene to middTe Miocene basin-fill deposits composed of clay, silt, sand, and gravel.

TpE CONSOLIDATED BEDROCK--Tertiary to Precambrian rocks consisting of sedimentary, metamorphic, and igneous rocks. Includes undifferentiated volcanic and intrusive rocks.

\section{INFERRED CONTACT}

\section{WATER-QUALITY DATA}

ESTIMATED CONCENTRATION OF DISSOLVED SOLIDS IN WATER, IN MILLIGRAMS PER LITER, AND WATER-QUALITY ZONES (All contacts between water-quality zones are gradational).

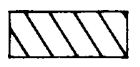

Less than 1000

- Freshwater

$::::::: \vdots$

1000 to 3000

- Slightly saline water

Greater than 3000 - Saline water

\section{WELL DATA}

- क TOTAL DEPTH OF WELL, IN FEET

$\circ$

$\stackrel{\rightarrow}{\rightarrow}$ WELL LOCATION NUMBER--Parentheses around

- the well number indicate the well is

$\bar{m}$ projected to the section line at a right in angle.

ㄴ

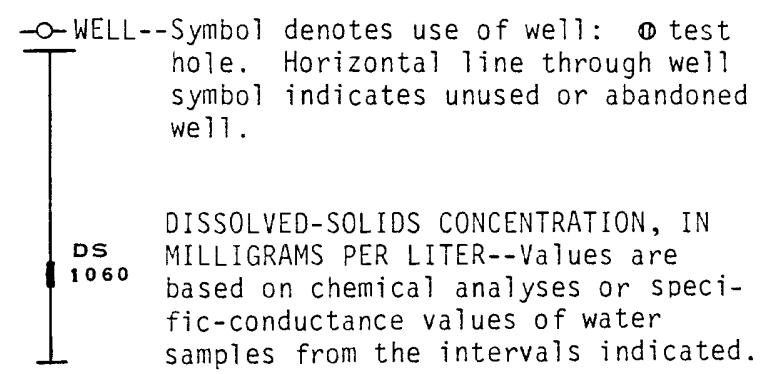

\section{VERTICAL ELECTRICAL - SOUNDING DATA}

* BEND IN SECTION

$\stackrel{\bar{m}}{m}$

$x$ VERTICAL ELECTRICAL SOUNDING
$\pm \mathbf{1 2 3}$ RESISTIVITY-- Number is the true
\pm 206 resistivity, in ohmmeters, of
\pm 104 interval. Intervals separated
by $\perp$.

Figure 13.--Geohydrologic sections $L-L^{\prime}$ through $N-N^{\prime}$, Rhodes Canyon alluvial fans, White Sands Missile Range. 


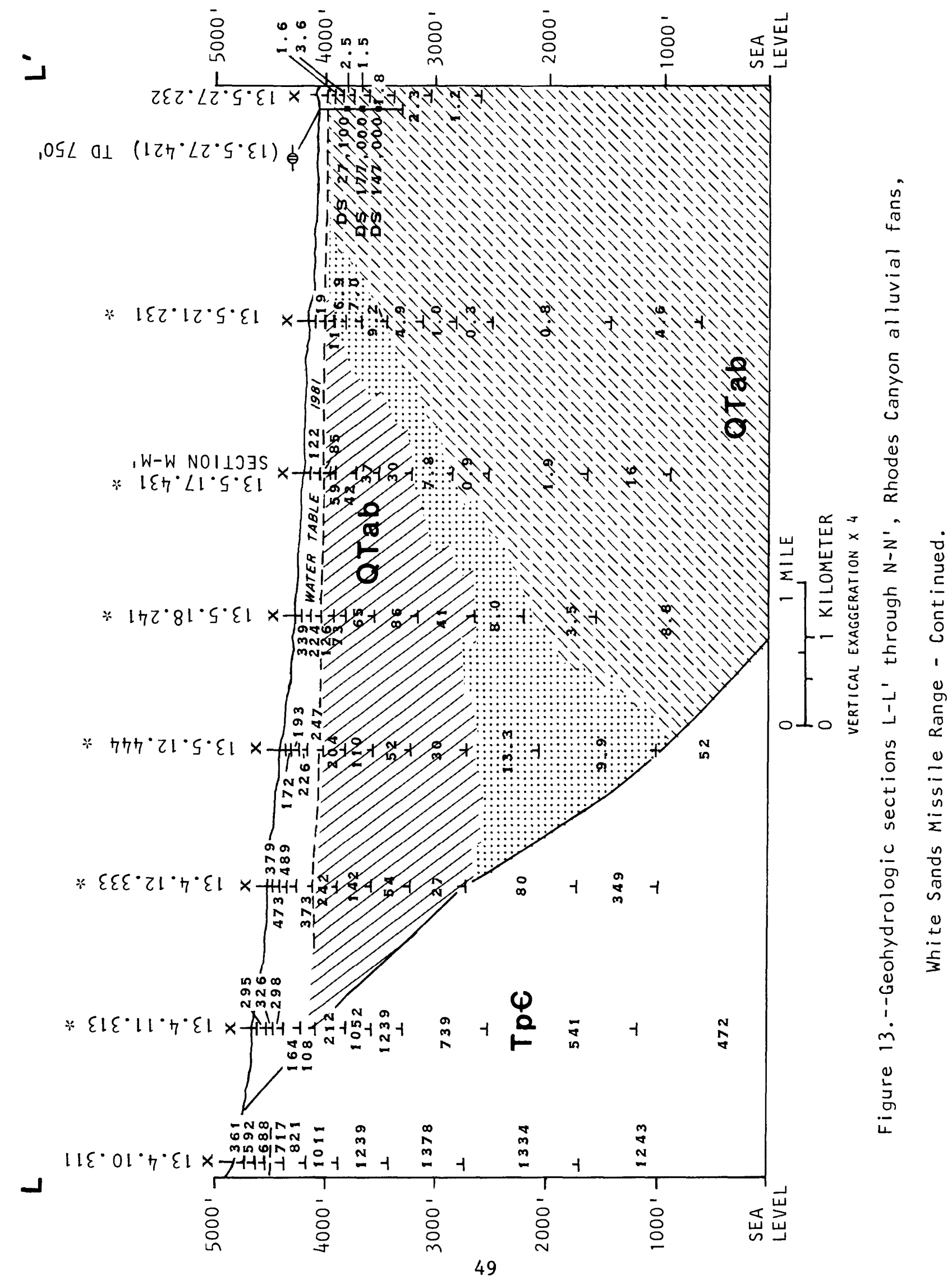




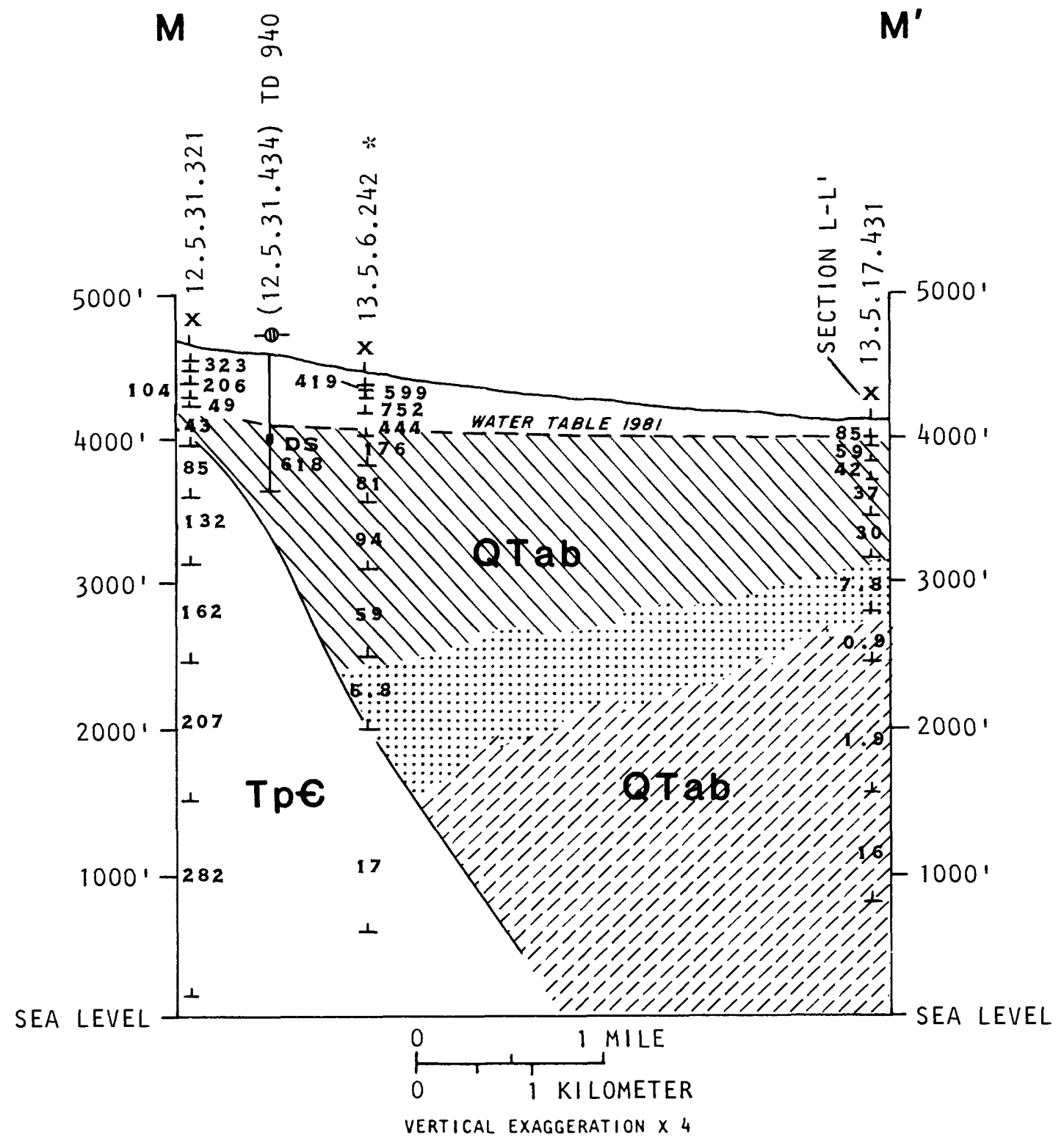

Figure 13.--Geohydrologic sections $L-L^{\prime}$ through $N-N^{\prime}$, Rhodes Canyon alluvial fans, White Sands Missile Range - Continued. 

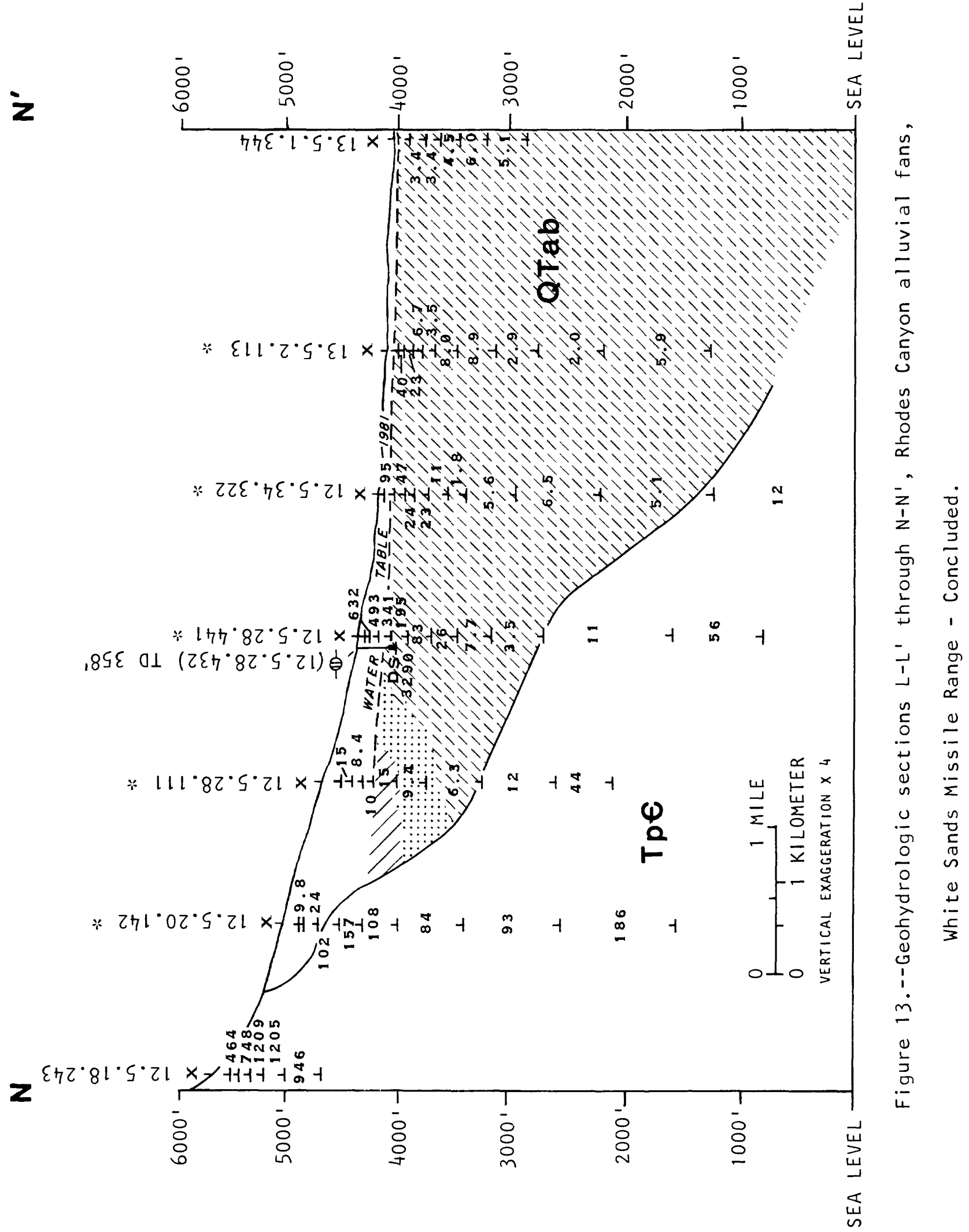


\section{Ash Canyon alluvial fan}

Alluvial-fan deposits at the mouths of Ash Canyon and Little San Nicolas Canyon ( $f i g$. 14) are known to contain some freshwater resources. The MAR Site well field, consisting of two supply wells (MAR SW-1 and MAR SW-2) and three test wells (test wells MAR-1, MAR-2, and MAR-3), was developed in 1963 in these freshwater-saturated deposits to supply water to a White Sands Missile Range facility. Test well MAR-4 was drilled in 1967. Seven surface electrical-resistivity soundings (fig. 14) were conducted near the MAR Site well field in 1982 to more precisely evaluate the extent of the freshwater resources and the approximate interfaces, both laterally and with depth, of water-quality zones in these saturated alluvial-fan deposits.

Two hydrologic sections, $0-0^{\prime}$ and $\mathrm{P}^{\prime} \mathrm{P}^{\prime}$ ( $\mathrm{fig}$. 15), were constructed from surface electrical-resistivity sounding data and available well information. Section 0-0', oriented west to east, runs directly through the MAR Site well field. Water-chemistry zones are approximately located based on analyses of water samples collected from different depth intervals in the MAR supply and test wells. The freshwater zone ranges in thickness from about 800 feet toward the fan apex to about 100 feet toward the east. The slightly saline $z$ one in this section ranges in thickness from 50 to 300 feet.

Section P-P' is oriented approximately north to south along Range Road 7 (fig. 14). From this section, the freshwater zone ranges in thickness from less than 100 to more than 500 feet. The slightly saline zone ranges in thickness from less than 50 to about 300 feet.

Both geohydrologic sections indicate that the transition from freshwater to saline water is very rapid with depth. Freshwater with a specific conductance of 726 microsiemens was present in test well MAR-1 in the interval from 582 to 718 feet; the interval from 827 to 1,000 feet in this same well contained saline water with a specific conductance of 68,700 microsiemens (Cooper, 1973, p. 55). This rapid increase in concentrations of dissolved solids with depth also was observed in test wells MAR-2 and MAR-3. The deeper section in test well MAR-4, close to the fan apex, yielded slightly saline water with a specific conductance of $2,150 \mathrm{microsiemens.} \mathrm{The} \mathrm{rapid} \mathrm{transition}$ could be attributed to limited vertical movement of water because of the small vertical hydraulic conductivity of the alluvial-fan aquifer.

A water-table map (fig. 14) constructed from available water-level data indicates that ground water flows east and northeast across the MAR Site well field. The hydraulic gradient is about 56 feet per mile near the fan apex, flattening basinward to about 11 feet per mile. Locally, ground water probably is recharged near canyon mouths and moves down gradient toward Lake Lucero where discharge may occur from the shallow water table through upward capillary movement and evaporation. 

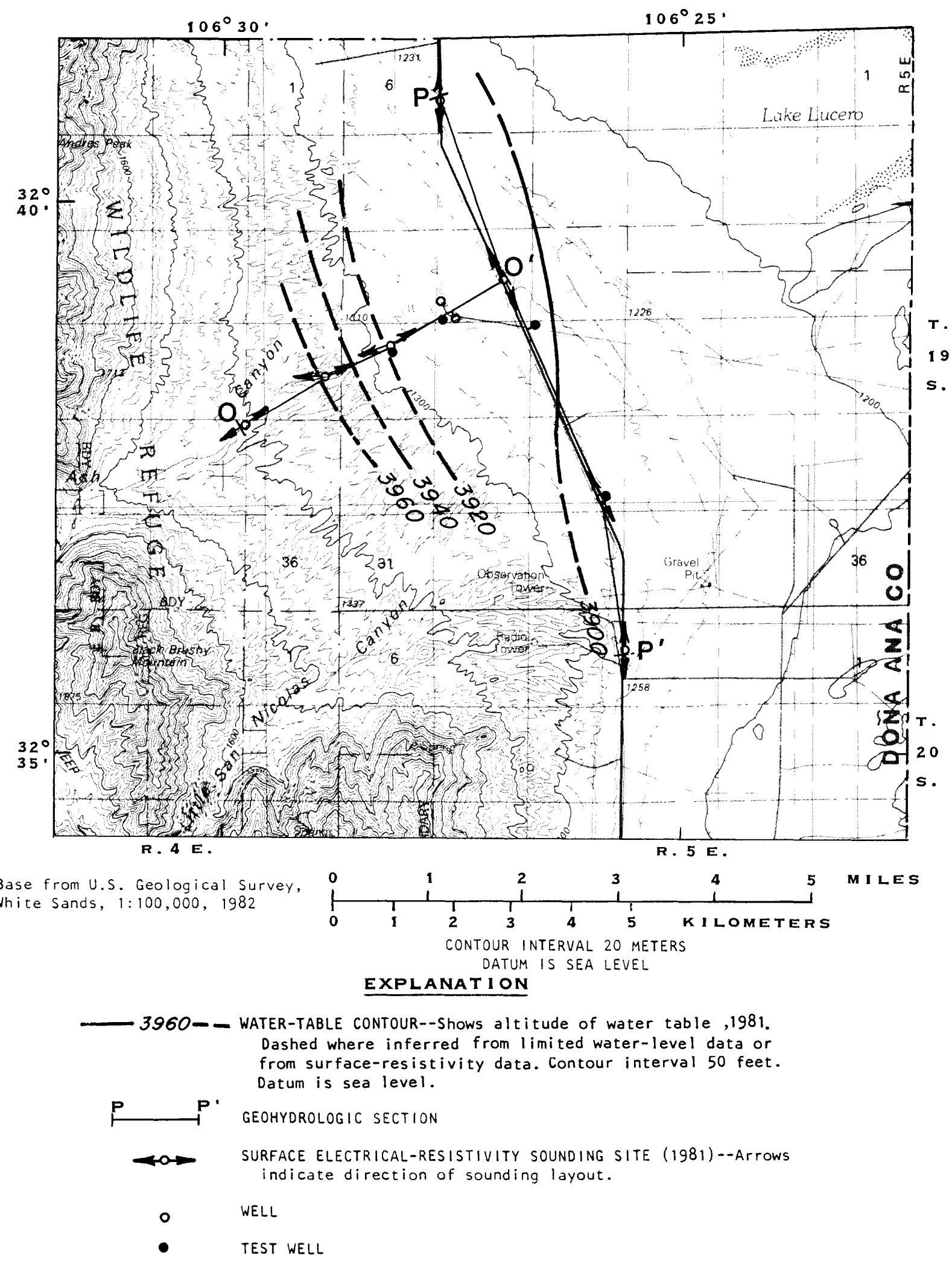

Figure 14.--Water table in the saturated basin-fill deposits of the Ash Canyon alluvial fan, White Sands Missile Range. 


\section{EXPLANATION}

\section{GEOLOGIC DATA}

QTab BOLSON DEPOSITS--Pleistocene to middle Miocene basin-fill deposits composed of clay, silt, sand, and gravel.

TpE CONSOLIOATED BEDROCK--Tertiary to Precambrian rocks consisting of sedimentary, metamorphic, and igneous rocks. Includes undifferentiated volcanic and intrusive rocks.

INFERRED CONTACT

\section{WATER-QUALITY DATA}

ESTIMATED CONCENTRATION OF DISSOLVED SOLIDS IN WATER, IN MILLIGRAMS PER LITER, AND WATER-QUALITY ZONES (A1) contacts between water-quality zones are gradational).

\begin{tabular}{|c|c|c|}
\hline 010 & Less than 1000 & - Freshwater \\
\hline [:::::::: & 1000 to 3000 & - Slightly saline water \\
\hline 11717] & Greater than 3000 & - Saline water \\
\hline
\end{tabular}

\section{WELL DATA}

$\overline{-}$ TOTAL OEPTH OF WELL, IN FEET

$\circ$

- WELL LOCATION NUMBER-- Parentheses around

$\checkmark$ the well number indicate the well is

o projected to the section line at a right ir angle.

官
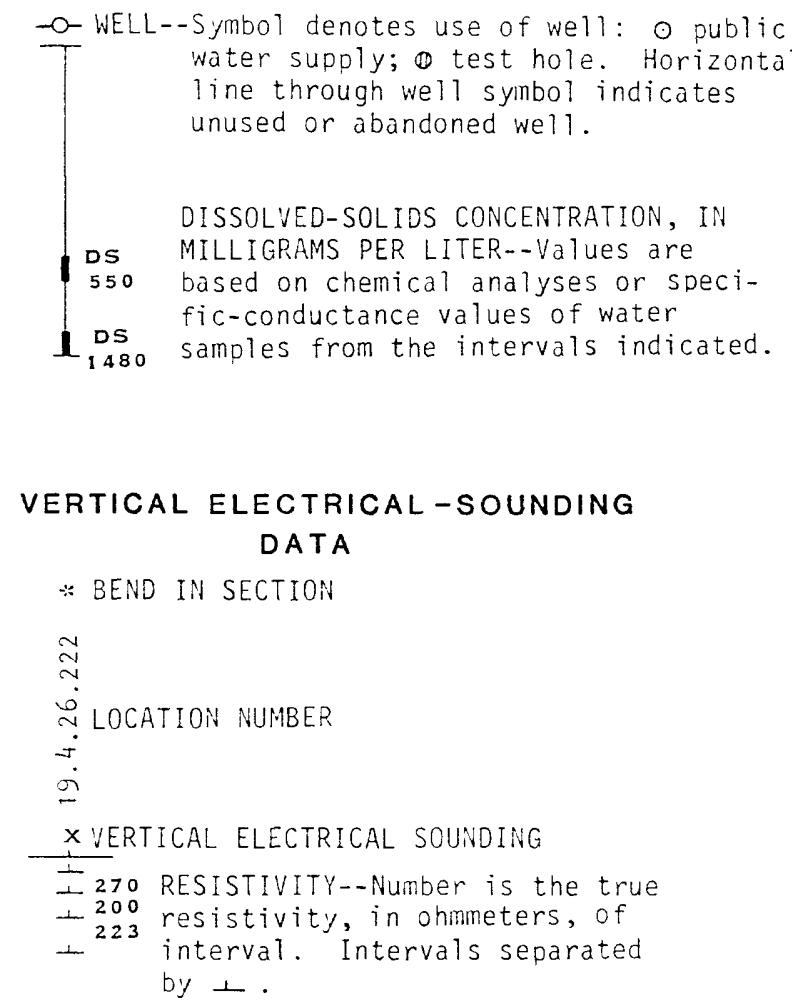

Figure 15.--Geohydrologic sections 0-0' and P-P', Ash Canyon alluvial fan, White Sands Missile Range. 


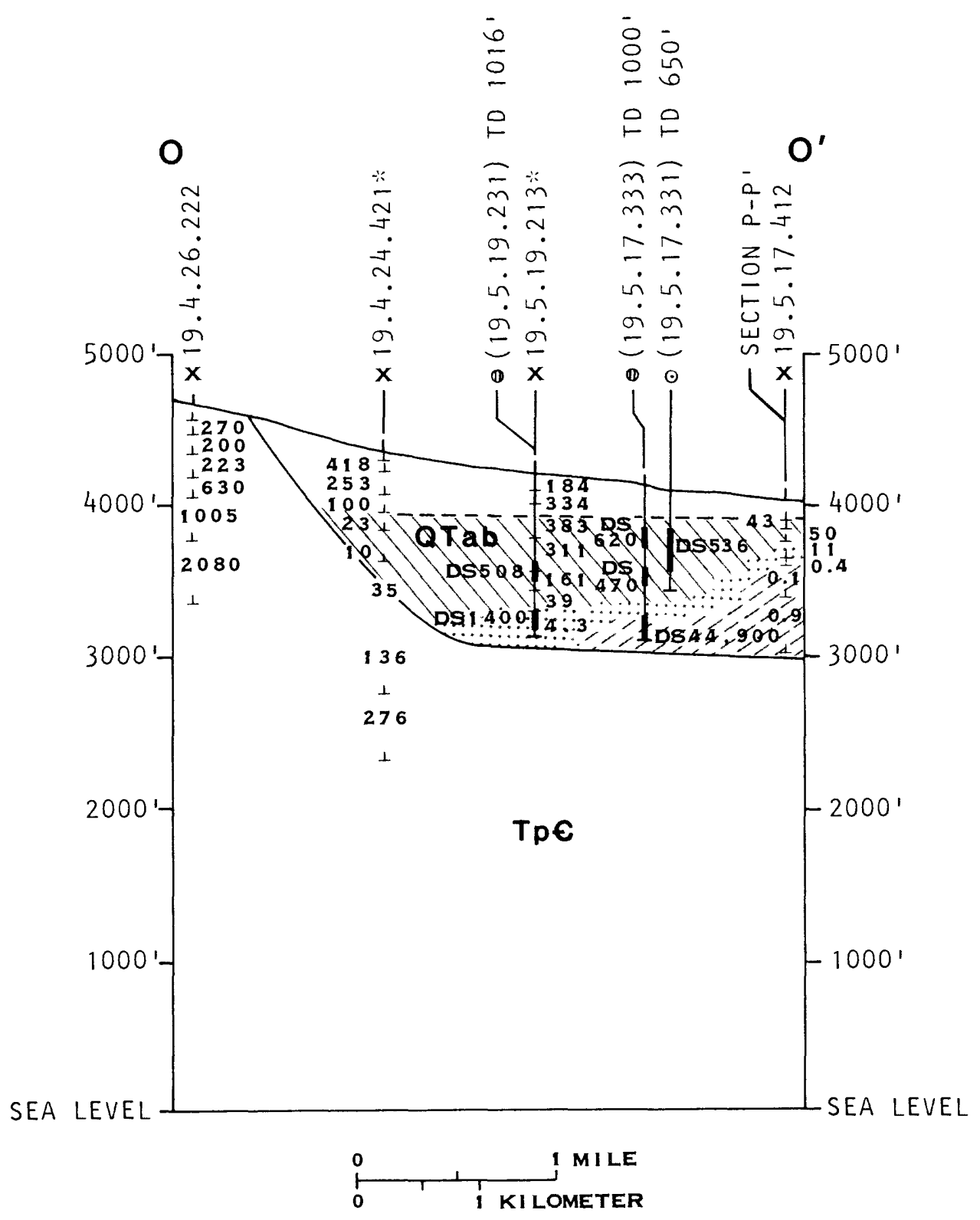

Figure 15.--Geohydrologic sections 0-0' and P-P', Ash Canyon alluvial fan, White Sands Missile Range - Continued. 


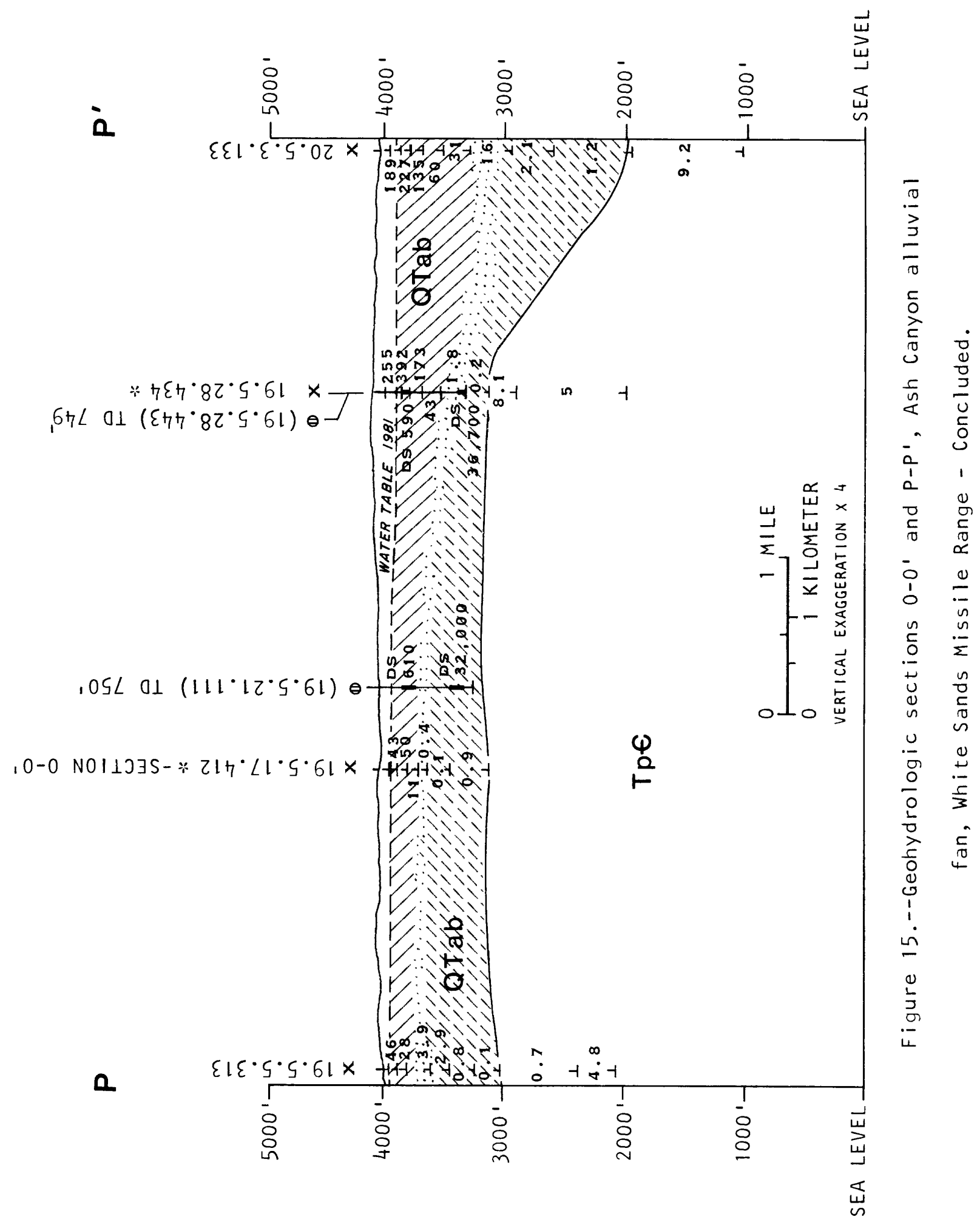


A freshwater saturated-thickness map (fig. 16) constructed from surface electrical-resistivity and well data indicates that the freshwater zone is more than 600 feet thick near the center of the fan, and thins to a feather edge east of Range Road 7. Based on figure 16, the volume of alluvial-fan sediments containing freshwater in the vicinity of the MAR site well field is estimated to be about $3 \mathrm{million}$ acre-feet. If the average specific yield of these sediments is about 15 percent (Herrick, 1960a, p. 98), the volume of freshwater in storage is about 450,000 acre-feet, not all of which is recoverable.

The presence of fresh ground water in the MAR Site well-field area indicates that similar freshwater resources could occur in alluvial-fan deposits to the north (fig. 17). The alluvial-fan deposits underlying the MAR Site well field were deposited at the mouths of two principal drainages, Ash Canyon and Little San Nicolas Canyon, and associated smaller drainages. These drainages encompass a total area of more than 24 square miles. Similar-sized drainage areas to the north could provide freshwater for recharge to alluvialfan deposits (fig. 17). Additional surface electrical-resistivity soundings and test-well drilling would be needed to assess the extent and availability of these resources.

\section{Saline Water in Central-Basin Deposits}

Basin-fill deposits in the central part of the Tularosa Basin predominantly are saturated with moderately saline water to brine. Dissolvedsolids concentrations in ground water exceed 100,000 milligrams per liter in places.

A limited number of water-quality analyses are available from wells completed in saline zones. Multiple analyses from we11 T-14 (22.5.15.221) indicate that sodium and chloride were the predominant ions from a depth of 2,590 to 6,000 feet (Doty and Cooper, 1970, p. 28). Concentrations of dissolved solids were as large as 112,000 milligrams per liter at depth in this well. Test well RC-3 (13.5.27.421) also produced very saline water in which sodium and chloride were the predominant ions (Cooper, 1973, p. 74). Concentrations of dissolved solids were as large as 177,000 milligrams per liter. Saline water from other wells generally contained large concentrations of sodium and chloride.

In contrast, the Gregg test well and Gregg supply well (22.6.8.414 and $414 \mathrm{a}$ ) produced saline water in which the predominant ions were sodium and sulfate (Cooper, 1973, p. 17-21). Analyses are from samples collected in the upper 500 feet of basin-fill deposits. Concentrations of dissolved solids were as large as 13,900 milligrams per liter. A shallow well (16.6.32.241), located in the evaporite playa north of Lake Lucero, produced water in which predominant ions included sodium, chloride, and sulfate. The concentration of dissolved solids was 57,600 milligrams per liter. 


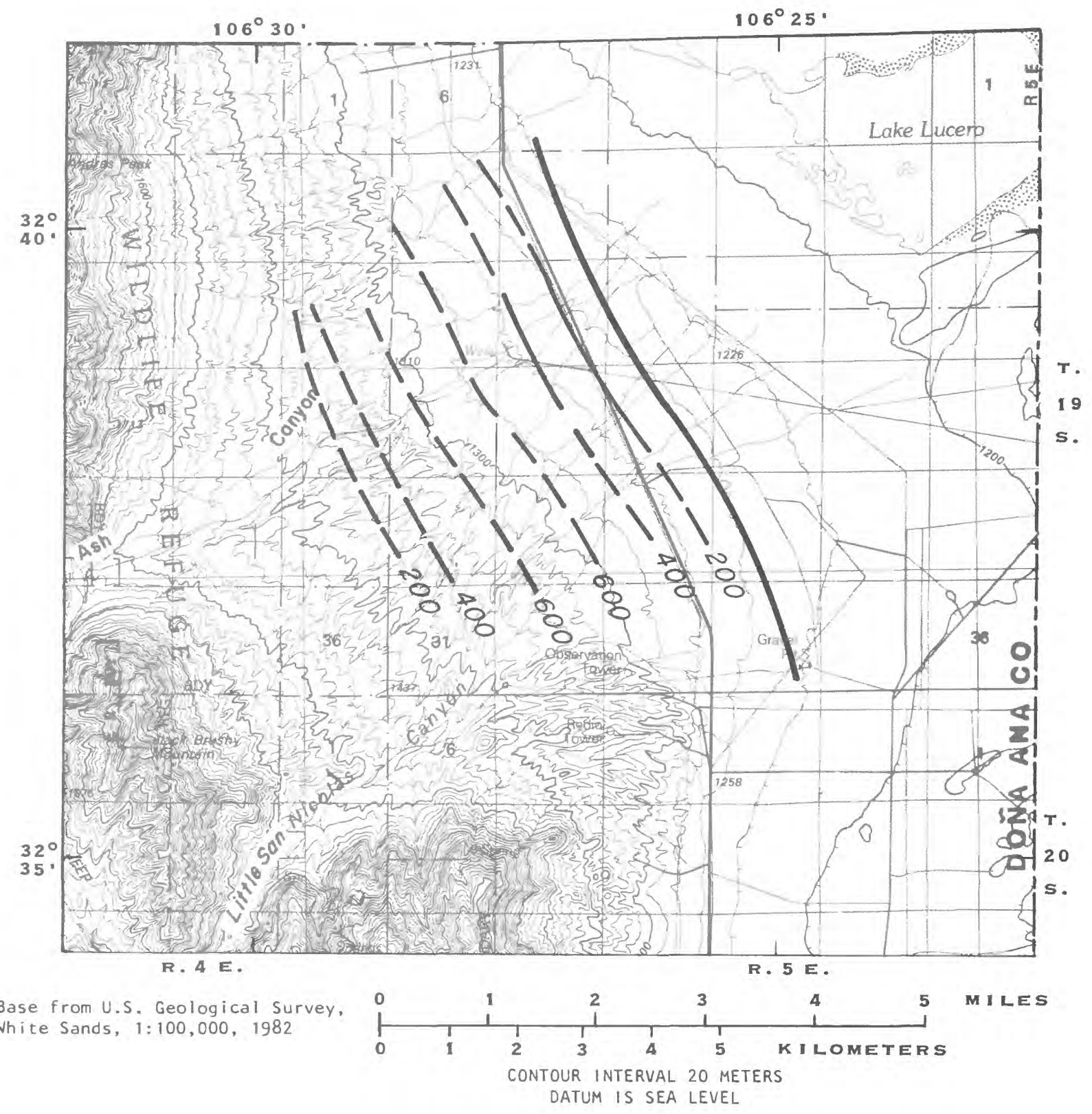

EXPLANATION

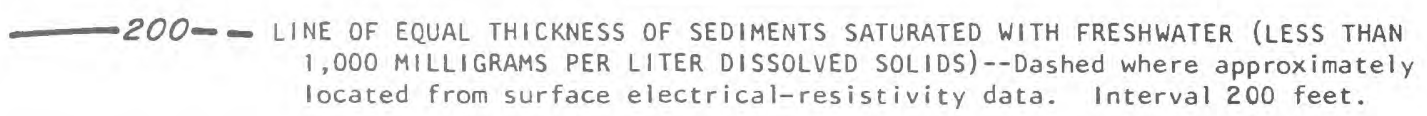
1,000 MILLIGRAMS PER LITER DISSOLVED SOLIDS) --Dashed where approximately EASTERN EXTENT OF FRESHWATER ZONE

Figure 16.--Thickness of sediments saturated with freshwater, Ash Canyon alluvial fan, White Sands Missile Range, 1981. 


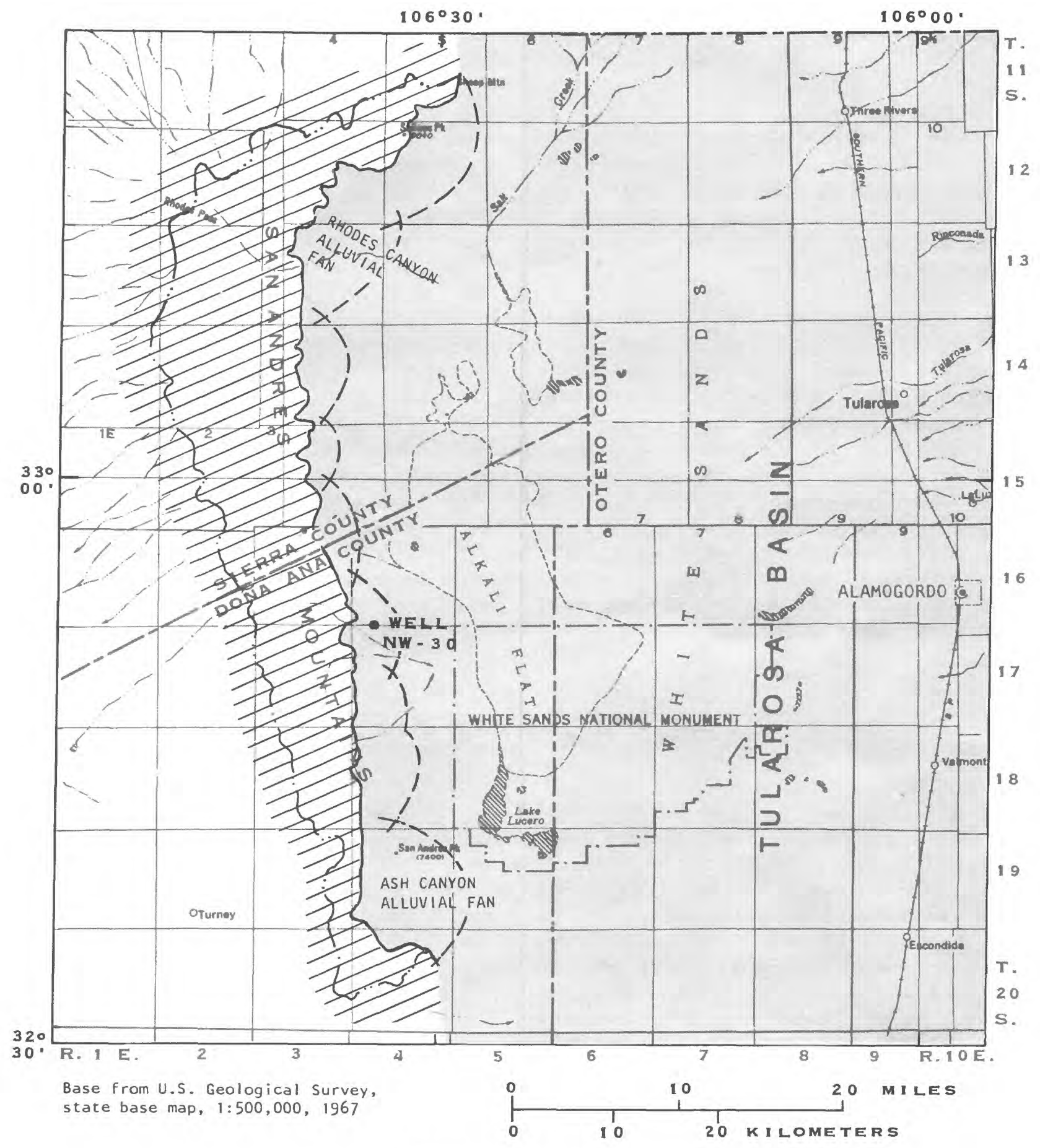

EXPLANATION

$\exists$ pre-tertiary consolidated rock

CONTACT BETWEEN CONSOLIDATED ROCK AND

BASIN-FILL DEPOSITS

- - aPPRoximate extent of ALLUVIAL-FAN DEPOSITS

-... WATERSHED BOUNDARY

Figure 17.--Location of potentially freshwater-bearing alluvial fans on the western side of the study area. 


\section{HYDROLOGIC PROPERTIES OF BASIN-FILL DEPOSITS}

Few wells have been drilled in much of the Tularosa Basin, primarily because of the very large concentrations of dissolved solids in ground water and because of the anticipated small permeability of aquifers within the central-basin sediments. Consequently, lithologic and hydrologic data are limited for the areas within the basin where saline ground water occurs. Geohydrologic information that has been collected must be extrapolated over large areas to assess the availability of saline ground water in the basin.

The capability of basinal water-bearing sediments to store and transmit ground water is closely linked to their individual grain size and degree of sorting. Coarser grained sediments generally are characterized by larger permeability; such sediments typically are associated with alluvial, fluvial, or eolian deposits. More uniformly sorted sediments generally have greater permeability than do poorly sorted sediments. Alluvial-fan material is poorly sorted close to source areas; more uniform sorting occurs basinward, as does the deposition of increasingly finer grained material. Finer grained sediments are characterized by smaller permeabilities; these sediments typically are associated with lacustrine, playa, and distal-fan deposits. In the Tularosa Basin, saline ground water occurs in all of these deposits; consequently, the capability of these deposits to store and transmit saline water may vary widely from place to place.

\section{Hydrologic Properties of Alluvial Fans}

Alluvial fans bordering the Tularosa Basin contain the only known fresh and slightly saline ground-water resources in the basin. Consequently, most of the data describing aquifer properties have been collected from wells in these fan deposits. On the eastern side of the basin, hydrologic data are available primarily from the Holloman Air Force Base well fields. Some data are available from wells belonging to the city of Alamogordo, irrigation wells in the Tularosa area, and wells in the Three Rivers area. On the western side of the basin, hydrologic data are available from test and supply wells in the Soledad Canyon area, in the vicinity of the White Sands Missile Range post Headquarters, near the Small Missile Range, the MAR well field, the NW-30 supply well, and test wells near Rhodes Canyon. Saline water occurs at depth in most of these areas.

\section{Eastern Side of the Tularosa Basin}

Extensive development of fresh ground-water resources has occurred in the well fields of Holloman Air Force Base and in the irrigated farmland near Tularosa. Some hydrologic data are available from the Holloman well fields (Hood, 1958; Mclean, 1970; Ballance, 1976; and Garza and McLean, 1977). However, most ground-water development on the east side of the basin has been poorly documented, and a precise evaluation of the hydrologic characteristics of alluvial fans in much of this area is not feasible. 


\section{Holloman Air Force Base well fields}

Holloman Air Force Base well fields are located on alluvial fans south of Alamogordo and include the Boles, Douglass, and San Andres well fields (fig. 5). The Boles and San Andres well fields are owned by the Air Force. The Douglass well field is privately owned, and the Air Force purchases water from the owner. Holloman Air Force Base first began pumping from the Boles well field in 1947, from the Douglass well field in 1961, and from the San Andres well field in 1963. These well fields presently (1983) provide approximately 70 percent of the water used by Holloman Air Force Base.

Between 1947 and 1955, Holloman Air Force Base drilled 42 wells and test holes in the Boles well field. Some aquifer-test data are available from these wells. Hood (1958) presented these test data and analyses. McLean (1970) and Garza and McLean (1977) described the aquifer characteristics of alluvial-fan aquifers in the vicinity of the Boles well field. From these studies, the average transmissivity for aquifers underlying the Boles well field was determined to be between 1,330 and 2,340 feet squared per day based on the Theis nonequilibrium solution (Garza and McLean, 1977, p. 36). Garza and Mclean estimated that the average transmissivity for alluvial fans extending from Grapevine Canyon to the Tularosa area probably is between 1,000 and 1,330 feet squared per day. They estimated that the specific yield in the long term probably is between 8 and 12 percent, although aquifer tests indicated that the aquifer responds to short-term pumping stress as a leakyconfined system, with storage coefficients ranging from $1 \times 10^{-3}$ to $5 \times 10^{-3}$ (Garza and Mclean, 1977, table 10). Small values for the storage coefficients, which are indicative of confined systems, may be due to the effect of interbedded clays that restrict vertical flow in the aquifer.

Limited information is available on well-construction details in the Boles well field. Tabulated data indicate that these wells generally are less than 300 feet deep and penetrate an average saturated thickness of less than 200 feet (Garza and McLean, 1977, table 3). The saturated sediments include thinly interbedded clay, silt, sand, and gravel typical of alluvial-fan deposits. If the interbedded clay units significantly affect vertical flow in the aquifer, then radial flow as assumed in the Theis nonequilibrium solution for transmissivity may occur only in the production interval, with overlying and underlying sediments essentially responding to stress as leaky-confining units. Assuming that the aquifer-test data are representative only of the production interval and that wells are screened across the entire saturated thickness penetrated by the well, average hydraulic-conductivity values can be estimated by dividing the estimated transmissivity by that saturated thickness. The average hydraulic conductivity for all units comprising the aquifer may be from 6 to 12 feet per day based on average transmissivity values estimated by Garza and McLean (1977) and an average saturated thickness of 200 feet. Borehole-geophysical logs, well-construction information, and carefully designed aquifer tests are needed to better define the hydraulic conductivity of specific water-yielding sand and gravel units in the Boles well field. 
The San Andres well field consists of four wells, which have yields ranging from 500 to 1,000 gallons per minute (Ballance, 1976, p. 8). The privately owned Douglass well field to the west consists of six production wells, which have yields ranging from 300 to 700 gallons per minute. Ballance (1976, p. 24) indicated that the eastern part of the San Andres well field (closest to the Sacramento Mountains) is characterized by larger values for the storage coefficient and transmissivity than those of the Douglass we 11 field and western part of the San Andres well field. Ballance estimated the specific yield of the aquifer in the vicinity of San Andres well 4 to be about 12 percent. The transmissivity of the aquifer penetrated by San Andres well 4 was determined to be about 20,000 feet squared per day based on the Theis nonequilibrium equation (Ballance, 1976, p. 16). If this transmissivity estimate is representative of the entire saturated thickness penetrated by the well, the average hydraulic conductivity of sand units in this interval probably is greater than 23 feet per day.

Transmissivity estimates for the western part of the San Andres well field and for the Douglass well field range from 1,200 to 3,700 feet squared per day (Ballance, 1976, p. 16). A specific yield of about 9 percent was calculated for the aquifer in these areas based on water-level declines resulting from well pumpage.

San Andres well $3(17.10 .31 .424)$ was drilled in 1965 to a depth of 2,000 feet, was plugged back to 965 feet, and was finished with slotted casing from 180 to 942 feet. Geophysical $\operatorname{logs}$ indicate that approximately 40 percent of the lithology from 180 to 942 feet consists of sand and gravel.

A 9-hour step-drawdown test was conducted on San Andres well 3 on February 25, 1966 (W. C. Ballance, written commun., 1966). The discharge during this test ranged from about 650 to 1,400 gallons per minute. The 9hour specific capacity, based on a time-weighted discharge of 1,035 gallons per minute, is 4.0 gallons per minute per foot of drawdown. A Theis semilog plot of early water-level drawdown data against time was used to estimate transmissivity from the first step of the test. From this plot (fig. 18), a transmissivity estimate of about 1,160 feet squared per day was made. The estimated average hydraulic conductivity of the permeable sand and gravel units in San Andres well 3 is 3.8 feet per day (table 1). The small value of hydraulic conductivity estimated from these test data indicates that the water-producing units penetrated by San Andres well 3 are equivalent to very fine to fine-grained sand (Lohman, 1972, p. 53). The basinward trend toward smaller hydraulic conductivities and specific yields from San Andres well 4 to San Andres well 3 may be the result of deposition of finer textured sediments farther from source areas to the east. The values of hydraulic conductivity estimated for both wells were based on data obtained from freshwater-saturated thicknesses of the aquifer. A similar aquifer saturated with very saline water may have significantly smaller values of hydraulic conductivity because of the increased kinematic viscosity of the water. 


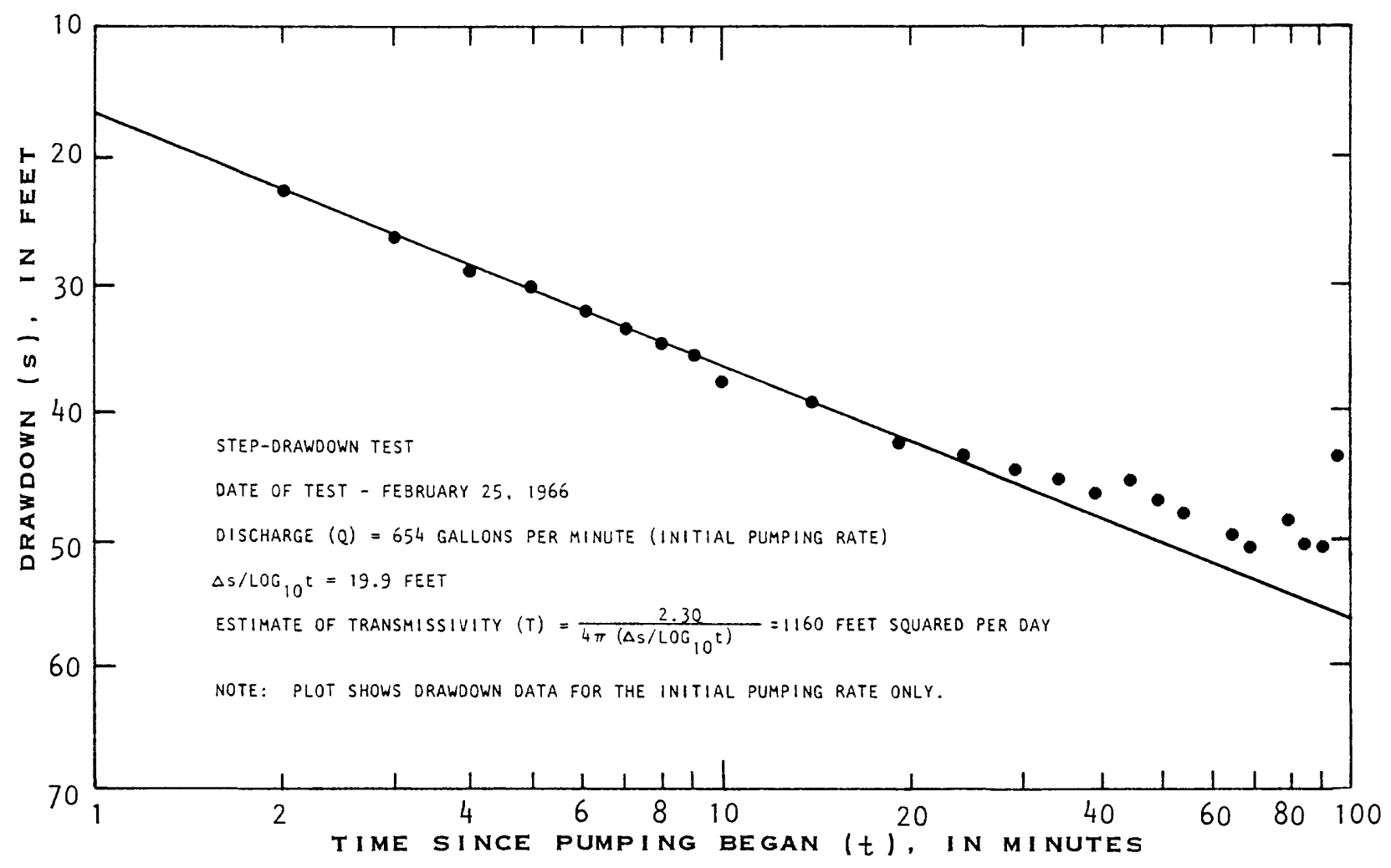

Figure 18.--Results of an aquifer test, San Andres well 3, Holloman Air

Force Base.

\section{Al amogordo-Tularosa we1ls}

Limited hydrologic information is available for the Alamogordo-Tularosa area. Specific capacities of wells are reported to range from 0.8 to 16.8 gallons per minute per foot of drawdown (McLean, 1970, p. 30). McLean (1970, fig. 12) indicated that transmissivities in the vicinity of Alamogordo may range from less than 1,000 feet squared per day near Holloman Air Force Base to as much as 20,000 feet squared per day near the mountain front. However, the lack of aquifer-test information in this area precludes estimates of hydraulic-conductivity values for water-yielding sands in the alluvial-fan deposits.

Specific capacities for wells in the Tularosa area ranged from 2.1 to 16 gallons per minute per foot of drawdown (McLean, 1970, p. 40). McLean reported two aquifer tests with transmissivity estimates of 2,100 and 4,200 feet squared per day. Again, limited information precludes estimating hydraulic-conductivity values for alluvial-fan deposits. Aquifer properties near Tularosa and near Alamogordo probably are highly variable because of the heterogeneity of the alluvial-fan deposits. These properties probably are similar to those to the south in the Holloman well fields. 


\section{Western Side of the Tularosa Basin}

A large amount of hydrologic data is available for the western side of the Tularosa Basin as a result of a long-standing cooperative agreement between the White Sands Missile Range and the Geological Survey. These data include borehole-geophysical logs, aquifer-test data, historical water-level and water-chemistry data, and we11-construction details. They provide the information to more precisely evaluate the hydrologic characteristics of alluvial-fan aquifers in the White Sands Missile Range area.

A technique for estimating transmissivity from well specific-capacity data (Theis, 1963, p. 332-336; and Brown, 1963, p. 336-338) was applied to specific-capacity data from selected wells in the Tularosa Basin (table 2). Most of the specific-capacity data used in this analys is was derived from tests of wells completed in alluvial-fan deposits on White sands Missile Range. This technique requires the test duration, the effective well radius, and the aquifer storage coefficient. The test duration was known. The diameter of drill holes and well casings was used to estimate the effective well radius. Because the alluvial deposits generally contain much interbedded clay, an artesian storage coefficient of $10^{-3}$ was assumed.

For the majority of we11s 1isted in table 2, estimates of transmissivity were similar to or smaller than transmissivity derived from aquifer tests. Transmissivity estimates that were significantly smaller than calculated transmissivity values may indicate that these wells were affected by losses due to well inefficiency. Estimates of transmissivity for the remaining wells in table 2 were significantly larger than the transmissivities derived from aquifer tests. In order to more closely match aquifer-test transmissivities, transmissivity estimates were recalculated using an assumed storage coefficient of 0.15 ( $t a b l e ~ 2)$, representative of water-table conditions. Most wells that appear to produce water from an unconfined aquifer are located directly north of the Post Headquarters area (fig. 19) where water-1evel declines since 1949 have exceeded 75 feet in response to long-term pumping stresses.

Analyses of specific-capacity data indicate that the alluvial-fan aquifers generally respond to pumping stress as being under confined conditions. Specific-capacity data $c$ an be used with care to estimate the magnitude of transmissivity; however, local geohydrologic conditions can significantly affect these estimates.

Alluvia1-fan deposits characteristically have large ranges in hydraulic conductivity both laterally and vertically because of the effect of variations in sorting and grain size. The extreme heterogeneity of these deposits and the type of rock contributing to them are both important factors in the determination of the capability of these deposits to transmit water. 


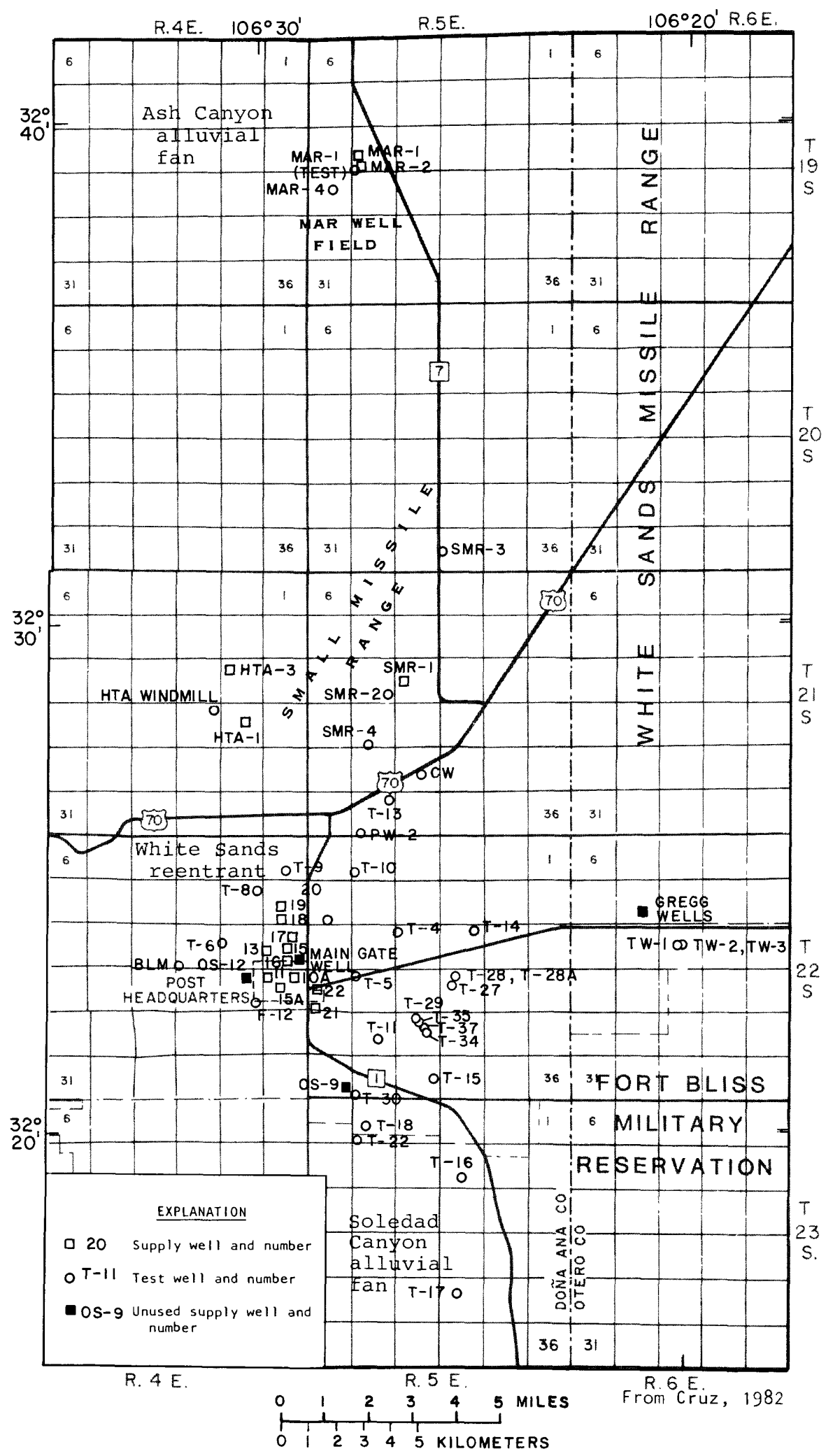

Figure 19.--Location of wells at White Sands Missile Range Post Headquarters and adjacent areas. 
The capability of freshwater-saturated alluvial-fan aquifers in the Tularosa Basin to transmit water varies from place to place as indicated by the large range of hydraulic-conductivity values (from 1 to more than 300 feet per day). This large range primarily is controlled by the heterogeneous deposition of clay, silt, sand, and gravel typical of alluvial-fan deposits, by the degree of sediment sorting, and by the basinward distribution by grain size of fan sediments. Generally, coarse-grained deposits occur close to source areas and are characterized by large hydraulic-conductivity values; finer grained deposits occur basinward and are characterized by small hydraulic-conductivity values. The sand percentage of alluvial-fan deposits penetrated by wells in the Tularosa Basin ranges from about 12 to more than 95 percent ( $t a b l e ~ 1)$. The transmissivity of a total saturated thickness of 500 feet of alluvial-fan deposits could range from about 70 feet squared per day, where a minimum percentage of $s$ and occurs and where sand units are very fine grained, to more than 140,000 feet squared per day where maximum percentages of coarse sediments occur. The range of hydraulic-conductivity estimates for alluvial-fan deposits primarily was derived from tests in freshwater or slightly saline water zones. As the dissolved-solids concentration of water saturating these deposits increases, the kinematic viscosity of this water will also increase and the average hydraulic conductivity will decrease.

\section{Soledad Canyon alluvial fans}

Test wel1s $\mathrm{T}-15, \mathrm{~T}-16, \mathrm{~T}-17$, and $\mathrm{T}-18$ (fig. 19) were drilled in the Soledad Canyon alluvial-fan deposits of White Sands Missile Range and Fort Bliss to evaluate the freshwater-resource potential. These wells penetrated coarse-grained alluvial deposits in the shallow subsurface and finer grained deposits at depth, which possibly can be correlated with the lacustrine deposits of the central basin.

Test we11 T-15 (22.5.33.244) was drilled in 1968 to a depth of 2,034 feet (Lyford, 1970, p. 14). Geophysical logs from this well indicate that alluvial deposits of interbedded sand, gravel, silt, and clay were penetrated from the 1 and surface to 876 feet. According to geophysical logs, permeable sand and gravel beds comprise about 29 percent of this interval. From 876 to 2,034 feet, clay predominates; thinly bedded sand units comprise only about 5 percent of this interval. The well casing was perforated opposite selected sand units in the upper alluvial deposits. No aquifer tests were conducted in this well.

Test we11 T-16 (23.5.10.413) was drilled in 1969 to a depth of 2,007 feet (Lyford, 1970, p. 18). Geophysical logs indicate that sand, gravel, silt, and clay interbeds were penetrated from the land surface to 927 feet. Permeable sand and gravel comprise approximately 67 percent of this interval. Clay and sand were penetrated from 927 to 1,482 feet; permeable sand units comprise approximately 38 percent of this interval. From 1,482 to 2,007 feet, clay again predominates with very thin sand interbeds comprising about 1 percent of the interval. 
An aquifer test, consisting of an 8 -hour pumping period and a subsequent recovery period, was conducted in well $\mathrm{T}-16$. The 8 -hour specific capacity at a pumping rate of 175 gallons per minute was 10.8 gallons per minute per foot of drawdown. Transmissivity estimates made from Theis semilog plots of waterlevel drawdown and residual-drawdown data were 5,020 and 4,790 feet squared per day (Lyford, 1970, p. 19). The production interval consisted of 100 feet of casing perforated at selected intervals from 310 to 700 feet. According to geophysical logs, permeable sand comprises about 96 percent of this interval. If radial flow is assumed only in the production intervals and the effect of vertical leakage on drawdown in the pumping well is assumed to be negligible, the average hydraulic conductivity for the sand units in these intervals is about 50 feet per day ( $t$ able 1 ).

According to the proximity microlog, about 67 percent of the interval from 182 to 927 feet and 38 percent of the interval from 927 to 1,482 feet are permeable sand. If the average hydraulic conductivity of the entire saturated thickness were as large as that in the tested interval, the transmissivity could be as much as 35,000 feet squared per day. This estimate probably is a maximum because the production intervals were selected from logs for their potential to yield water.

Well T-17 (23.5.27.142) was drilled in 1969 to a depth of 2,500 feet (Lyford, 1970, p. 25). The well casing was perforated for a total of 66 feet at intervals selected from geophysical logs. According to these logs, the well penetrated sand and clay interbeds from land surface to 1,112 feet ( 34 percent sand), predominantly clay with two thick sand units from 1,112 to 1,752 feet (28 percent sand), and clay with less than 1 percent sand from 1,752 to 2,500 feet.

An 8-hour aquifer test and subsequent recovery test were conducted in well $\mathrm{T}-17$. The 8-hour specific capacity was 5.7 gallons per minute per foot of drawdown at a discharge rate of 115 gallons per minute. The estimate of transmissivity calculated using the Theis solution ranged from 2,190 feet squared per day for the drawdown test to 2,380 feet squared per day for the recovery test (Lyford, 1970, p. 26-27).

According to proximity micrologs, the perforated interval includes 40 feet of sand. If the transmissivity estimates are representative of the perforated interval only, the average hydraulic conductivity for the sand units in the interval is about 60 feet per day based on the Theis recovery analysis (table 1 ). If the entire saturated thickness of sand and clay to a depth of 1,112 feet was as permeable as the tested interval, the transmissivity could be about 18,000 feet squared per day. Again, this estimate is probably a maximum because the tested intervals were selected from geophysical logs on the basis of their potential to yield water. 
Ten wells presently (1983) supply water for the White Sands Missile Range Post Headquarters area. A number of other wells, including abandoned supply wells, test wells, and boreholes, have been drilled in the vicinity of the Post Headquarters (fig. 19). Hydrologic data from these wells are available in reports by Davis and Busch (1968), Doty (1968c and 1968f), Hood (1968), Cooper (1970), Kelly (1973), Kelly and Hearne (1976), and Wilson and others (1978). Additionally, hydrologic-data reports are published annually as the result of a cooperative project between the U.S. Geological Survey and White Sands Missile Range.

Transmissivity estimates are available from 21 wells in the vicinity of the White Sands Missile Range Post Headquarters area ( $t a b l e 1)$. These estimates were made from semilog straight-line plots of drawdown or residual drawdown (many of which have been published in previous reports) and range from 160 feet per day $(\mathrm{T}-8)$ to 79,000 feet per day (SW-20). Boreholegeophysical logs that $c$ an be used to estimate the total sand thickness of the production intervals are available for 14 of the 21 wells. The average hydraulic-conductivity value for these sand units ranges from 1.2 feet per day in well $\mathrm{T}-12$ to at least 210 feet per day in well sW-20. The range of estimated hydraulic-conductivity values in the Post Headquarters area indicates that sand units may range in texture from very fine to coarsegrained sand (Lohman, 1972, p. 53). This textural range can be expected in typical alluvial-fan deposits. The sorting of alluvial-fan material may also affect the hydraulic conductivity; poorly sorted sand units with a large range of grain sizes can be expected to have a smaller hydraulic conductivity than a well-sorted sand unit with a similar average grain size.

In wells where production intervals were selected on the basis of geophysical logs, the percentage of sand in the production intervals generally is large, exceeding 48 percent in all but one well ( $t a b l e 1)$. Wells that were screened over a large interval without regard to selecting specific sand units generally contain less than 45 percent sand across the production interval.

In the Post Headquarters area, many of the supply and test wells located in close proximity to each other and completed at similar depths have a wide range of hydraulic-conductivity values ( $t a b l e 1)$. The large range of values probably can be attributed in part to the lateral heterogeneity of the lithology and grain size of sediments comprising the alluvial-fan deposits. We11 T-12 was completed at a deeper interval and the hydraulic-conductivity estimate for sand units in the producing interval of this well is indicative of very fine grained sand or clay (Lohman, 1972, p. 53). The small value of hydraulic conductivity in this well may be similar to that of sand units within the lacustrine deposits at depth. 
A series of test wells, SMR-1, SMR-2, SMR-3, and SMR-4, was drilled in alluvial-fan deposits north of the White Sands reentrant in 1960 and 1966 (fig. 19). The purpose of these wells was to better define the freshwater supply for a White Sands Missile Range facility.

Test we11 SMR-1 (21.5.16.132) was drilled in 1960 to a depth of 600 feet and was cased to a depth of 473 feet (Hood, 1968, p. 71). According to the lithologic log, the well penetrated coarse-grained material (sand and gravel) to a depth of 125 feet, sand and clay from 125 to 425 feet, and predominant $1 y$ clay from 425 to 600 feet. A total of 128 feet of slotted casing was installed from 286 to 423 feet at intervals as selected on the basis of geophysical logs. Borehole-geophysical logs indicate a combined thickness of approximately 63 feet of permeable sand in the production zone.

An aquifer test was conducted on test well SMR-1. The 4-hour specific capacity of this well at a pumping rate of 100 gallons per minute was about 5.9 gallons per minute per foot of drawdown; the 12-hour specific capacity at a time-weighted discharge of 124 gallons per minute was about 4.5 gallons per minute per foot of drawdown. The transmissivity calculated from water-level recovery data was 1,053 feet squared per day (Hood, 1968, fig. 14 and p. 73). Based on this transmissivity, the average hydraulic conductivity for sand units in the production zone is about 17 feet per day.

Test well SMR-2 (21.5.17.424) was drilled in 1960 to a depth of 765 feet and was cased to a depth of 747 feet (Hood, 1968, p. 76-77). According to 1 ithologic $\operatorname{logs}$ of test well SMR-2, the well penetrated predominantly coarsegrained material to a depth of approximately 250 feet; from 250 to 765 feet, the well penetrated predominantly finer grained materials, including clay and silt. The casing was perforated from 295 to 588 feet and from 608 to 715 feet for a total perforated interval of 400 feet. Borehole-geophysical logs indicate about 68 feet of permeable sand in the production interval.

The 3.5-hour specific capacity calculated from a step-production test was 13 gallons per minute per foot of drawdown. The recovery part of the test was used to calculate a transmissivity of 2,670 feet squared per day (Hood, 1968, p. 80). Based on this transmissivity, the average hydraulic conductivity of sand units in the production interval is about 39 feet per day.

Test we11 SMR-3 (20.5.34.133) was drilled in 1966 to a depth of 1,010 feet and was cased to 1,000 feet (Doty, 1968d, p. 29). The production interval consists of a total of 200 feet of mi11-slotted casing at selected intervals. According to borehole-geophysical logs, about 170 feet of permeable sand and gravel are in the production interval.

An aquifer test was conducted on test well SMR-3 in January 1967. The 8hour specific capacity was 97 gallons per minute per foot of drawdown at a discharge of 212 gallons per minute. A transmissivity of 46,900 feet squared per day was calculated from a Theis semilog plot of residual drawdown (Doty, 1968d, fig. 8). Based on this transmissivity, estimated average hydraulic conductivity of sand units in the production interval is about 276 feet per day. 


\section{MAR Site well field}

The MAR Site well field is located about 11 miles north of the Small Missile Range wells (fig. 19). Four test wells and two supply wells were drilled in alluvial deposits of the Ash Canyon alluvial fan.

Geohydrologic and well-construction information is available for the MAR Site wells (Doty, 1968a and 1968b). MAR supply wel1 1 (19.5.17.331), drilled in 1963 to a depth of 650 feet, was perforated from 230 to 550 feet. According to geophysical logs, a total of 38 feet of permeable, thinly bedded sand units are in the production interval. From aquifer-test data, the 24hour specific capacity of MAR supply well 1 was 3.1 gallons per minute per foot of drawdown at a discharge of 114 gallons per minute (table 1 ). The semilog plot of residual drawdown (Doty, 1968b, fig. 6) indicated an estimated range of transmissivity values from 840 to 1,340 feet squared per day. The estimate of the average hydraulic conductivity for water-producing sand units, based on these estimates of transmissivity, ranges from 22 to 35 feet per day depending on which estimate is used.

MAR supply well 2(19.5.17.334), drilled in 1963 to a depth of 650 feet, was perforated from 227 to 650 feet. According to geophysical logs, the production interval consists of a total of 49 feet of thin sand units interbedded with clay. Aquifer-test data (Doty, 1968b, p. 4c) indicate that the 24 -hour specific capacity was 0.83 gallon per minute per foot of drawdown at a discharge of 96 gallons per minute. Based on a semilog plot of residual drawdown (Doty, 1968b, fig. 6), transmissivity estimates ranged from 600 to 1,036 feet squared per day. The average hydraulic-conductivity estimate for water-producing sand units in MAR supply well 2 is from 12 to 21 feet per day. The hydraulic-conductivity estimates for MAR supply wells 1 and 2 indicate that the producing units may be equivalent to very fine to mediumgrained sand (Lohman, 1972, p. 53).

\section{We11 NW-30}

We11 NW-30 (17.4.2.211) was drilled in 1967 in alluvial-fan deposits about 15 miles north of the MAR well field (fig. 17). This well was drilled to a depth of 1,010 feet and penetrated interbedded sand, gravel, and clay. According to borehole-geophysical logs, the percentage of clay increases with depth. Well NW-30 was plugged back to 670 feet and was completed with a total of 122 feet of mill-slotted casing at intervals selected from logs. The proximity microlog indicates that a total thickness of about 70 feet of permeable sand units could yield water to the production zone. 
An aquifer test was conducted on well NW-30 in February 1967. The 8-hour specific capacity calculated from this test was 8.0 gallons per minute per foot of drawdown based on an average discharge of 248 gallons per minute. The semilog straight-line plot of early-time drawdown data (fig. 20) indicated a transmissivity of about 1,100 feet squared per day. Discharge fluctuated throughout the test, and results are only an approximation because the analysis assumes a relatively constant discharge. Previous analyses of recovery data (Doty, 1968d, p. 22) used the residual drawdown from the later part of the recovery curve, which may have resulted in anomalously large transmissivity values. Based on this transmissivity, the average hydraulic conductivity of water-yielding sand units is about 16 feet per day.

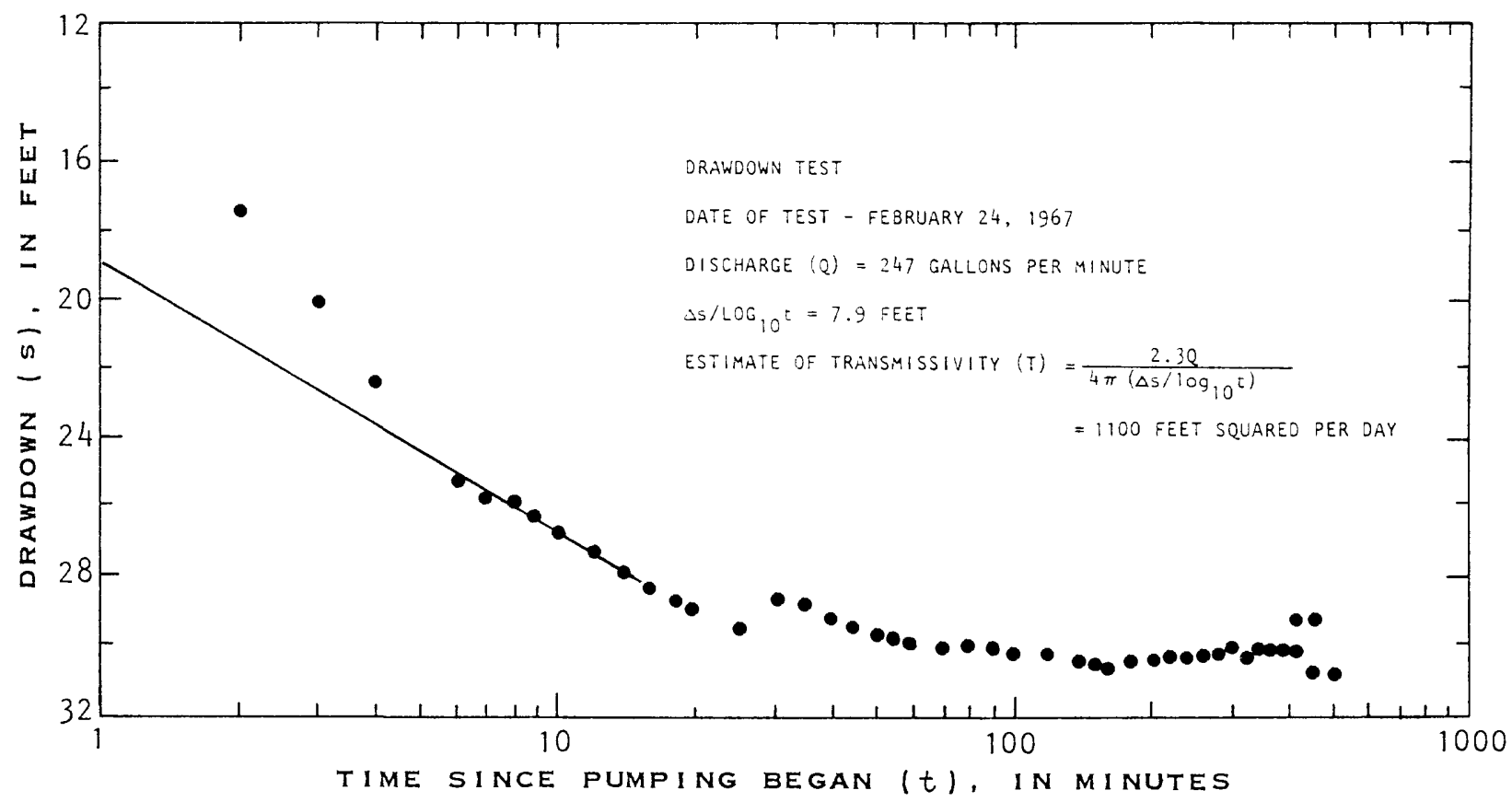

Figure 20.--Results of an aquifer test, well NW-30, White Sands Missile Range. 


\section{Hydrologic Properties of Fluvial and Eolian Deposits in the South-Central Part of the Tularosa Basin}

Few wells have been drilled in the extensive fluvial and eolian deposits in the south-central part of the Tularosa Basin. Wells for which aquifer-test data are available include the Gregg test well and Gregg supply well (22.6.8.414 and 414a). Stratigraphic test well T-14 provided some lithologic and water-chemistry information. Additional data are available from several other test and supply wells on White Sands Missile Range and Fort Bliss.

\section{Gregg Site We11s}

The Gregg site test well (22.6.8.414) and the Gregg site supply well (22.6.8.414a) were drilled in 1961 to evaluate the availability of saline water in an area approximately $8 \mathrm{miles}$ east of White Sands Missile Range Post Headquarters (fig. 19). The Gregg Site test well was originally drilled to a depth of 1,010 feet. According to Hood (1968, p. 56-57, table 3), the upper 500 feet of sediments penetrated by the Gregg Site test well consists of fine sand and interbedded clay; from 500 feet to the total depth of 1,010 feet, clay predominates. The percentage of sand in the upper 500 feet penetrated in the Gregg wells could not accurately be determined because of a lack of detail in borehole-geophysical logs.

The Gregg Site test well was cased to a depth of 500 feet and perforated with torch-cut slots in five intervals totaling 175 feet. The well was testpumped at 175 gallons per minute for 8 hours with 12.8 feet of drawdown (Cooper, 1973, p. 16); the 8-hour specific capacity was 14 gallons per minute per foot of drawdown. Using the Theis-Brown technique for estimating transmissivity from specific capacity (Theis, 1963, p. 332-336; Brown, 1963, p. 336-338) and assuming a storage coefficient of $1 \times 10^{-3}$, the transmissivity for the production interval in this well was estimated to be about 3,000 feet squared per day (table 2).

The Gregg Site supply well was drilled and cased to a depth of 478 feet; the casing was perforated with 145 feet of torch-cut slots from 265 to 465 feet. A step-drawdown test was conducted on the Gregg Site supply well on October 30, 1961. At the end of the 11-hour test, the drawdown was 60 feet at a discharge of 760 gallons per minute; the 11-hour specific capacity was approximately 13 gallons per minute per foot of drawdown. The transmissivity calculated from the semilog straight-line plot was approximately 2,620 feet squared per day (Hood, 1968, fig. 11). This calculated value of transmissivity is consistent with the transmissivity estimate made from the specific capacity of the Gregg Site test well. Based on this transmissivity, the average hydraulic conductivity for the entire production interval is approximately 18 feet per day. The average hydraulic conductivity for permeable sand units within the production interval probably exceeds 18 feet per day, assuming that a percentage of the total thickness of the production zone consists of clay. 


\section{We11s $T-16$ and $T-17$}

The fluvial and eolian deposits of the south-central part of the basin probably grade into the alluvial-fan deposits flanking the Organ Mountains. If this is the case, sand, clay, and gravel penetrated in wells T-16 (23.5.10.413) and $T-17(23.5 .27 .142)$ may provide information about the 1ithologic and hydrologic characteristics of basinward deposits.

Wel1 T-16 penetrated 927 feet of alluvial deposits before entering a predominantly clay unit. Permeable sand and gravel units comprise about 67 percent of the total thickness. The average hydraulic conductivity of sand units in the production interval is estimated to be about 50 feet per day (table 1). Well T-17 penetrated 1,112 feet of sand and clay overlying a thick sequence of clay. Permeable sand units comprise about 34 percent of the section in well $\mathrm{T}-17$. The average hydraulic conductivity for the production interval in well $\mathrm{T}-17$ is about 60 feet per day (table 1). These hydraulicconductivity values are calculated for freshwater zones. The hydraulic conductivity for similar aquifers saturated with very saline water probably would be smaller because of the increased kinematic viscosity of the water.

Lithologic and geophysical logs of wells in the vicinity of the New Mexico-Texas State line (Knowles and Kennedy, 1958, p1. 4, 5, and 7; Rapp, 1958, p. 23-82) indicate the presence of extensive sand, gravel, and clay deposits south from White Sands Missile Range into the Hueco Bolson. These deposits appear to be more than 500 feet thick in places and probably are underlain by fine-grained lacustrine sediments. The El Paso deep test well penetrated 600 feet of similar deposits. Limited information for the area east of Highway 54 suggests that fluvial-eolian deposits in that area generally are less than 200 feet thick. The percentage and grain size of sand in these fluvial and eolian deposits decrease eastward away from sediment source areas in the Organ and Franklin Mountains.

If the sediments in the south-central part of the Tularosa Basin are a northward extension of the coarse-grained sediments of the Hueco Bolson penetrated in the El Paso deep test well, they may comprise an extensive aquifer, mostly saturated with saline water. The thickness of this aquifer may range from less than 180 feet (we11 T-14) to more than 500 feet in places. The average hydraulic conductivity of sand units in this aquifer may range from much less than 18 feet per day toward the central part of the basin to as much as 60 feet per day closer to sediment source areas to the west. The total sand percentage of the aquifer may be 30 percent or less in the basin center, increasing to as much as 50 percent toward source areas. Transmissivity values may range from less than 1,000 feet squared per day to more than 15,000 feet squared per day. Central-basin alluvial deposits probably will respond to short-term pumping stress as a leaky-confined aquifer. Water-table conditions probably will be approached under long-term pumping stress. Test wells and carefully designed aquifer tests would be required at selected sites throughout the south-central part of the basin to define more precisely the availability and extent of saline water from these fluvial and eolian deposits. 
Hydrologic Properties of Lacustrine Deposits

in the Central Part of the Tularosa Basin

Few wells have been drilled and tested in the very fine grained sediments that comprise the lacustrine deposits in the Tularosa Basin. Well T-14 (fig. 19) penetrated approximately 3,440 feet of these deposits before entering a predominantly sand section. Well RC-3 drilled near the Rhodes Canyon area (fig. 12) penetrated 750 feet of clay. The Atlas test wells (At 1 as $\mathrm{T}-1, \mathrm{~T}-2$, and $\mathrm{T}-4, \mathrm{fig} .21$ ), drilled near the Holloman high-speed test track, penetrated over 400 feet of predominantly fine-grained sediments. Geohydrologic data collected from these and other wells provide some information about the capability of thin permeable sands within the predominantly clay sediments to store and transmit saline water.

\section{Holloman Air Force Base At las Wells}

At 1 as test well T-1 $(16.8 .13 .400)$ was drilled in May 1956 to a depth of 402 feet (fig. 21). According to lithologic and geophysical logs, this test well penetrated clay with about $40 \mathrm{feet}$ of thin sand beds. This test well reportedly yielded less than 50 gallons per minute with as much as 200 feet of drawdown after 12 hours of pumping and surging. The 12-hour specific capacity of this well was probably less than 0.2 gallon per minute per foot of drawdown. A transmissivity of about 60 feet squared per day was estimated from this specific capacity. If approximately 40 feet of sand were penetrated by well $\mathrm{T}-1$, the average hydraulic conductivity for the water-yielding sand intervals would be about 1.5 feet per day.

Atlas well T-2 (16.9.4.400) was drilled in 1956 to a depth of 412 feet (fig. 21). Perforated casing was installed from 74 to 412 feet. Geophysical logs indicate that sand and gravel comprise about 26 percent of the production interval. Data from a production test of Atlas well $\mathrm{T}-2$ were used to calculate a 4-hour specific capacity of 1.5 gallons per minute per foot of drawdown at a pumping rate of 60 gallons per minute. A transmissivity estimate of about 380 feet squared per day was derived from the specific capacity. The average hydraulic conductivity of the sand units in the production interval is estimated to be less than 5 feet per day.

At las well T-4 (16.9.8.100) was drilled in 1956 to a depth of 403 feet (fig. 21). A total of 258 feet of perforated casing was installed at selected zones. According to geophysical $\log s$, sand units comprise about 28 percent of the production interval. From a step-drawdown production test of this well, the 12-hour specific capacity was about 0.6 gallon per minute per foot of drawdown at a time-weighted discharge of about 78 gallons per minute. The specific-capacity estimate of transmissivity was about 160 feet squared per day. From this transmissivity estimate, an average hydraulic-conductivity value of 2.2 feet per day was estimated for the sand units in the production interval of the well. 


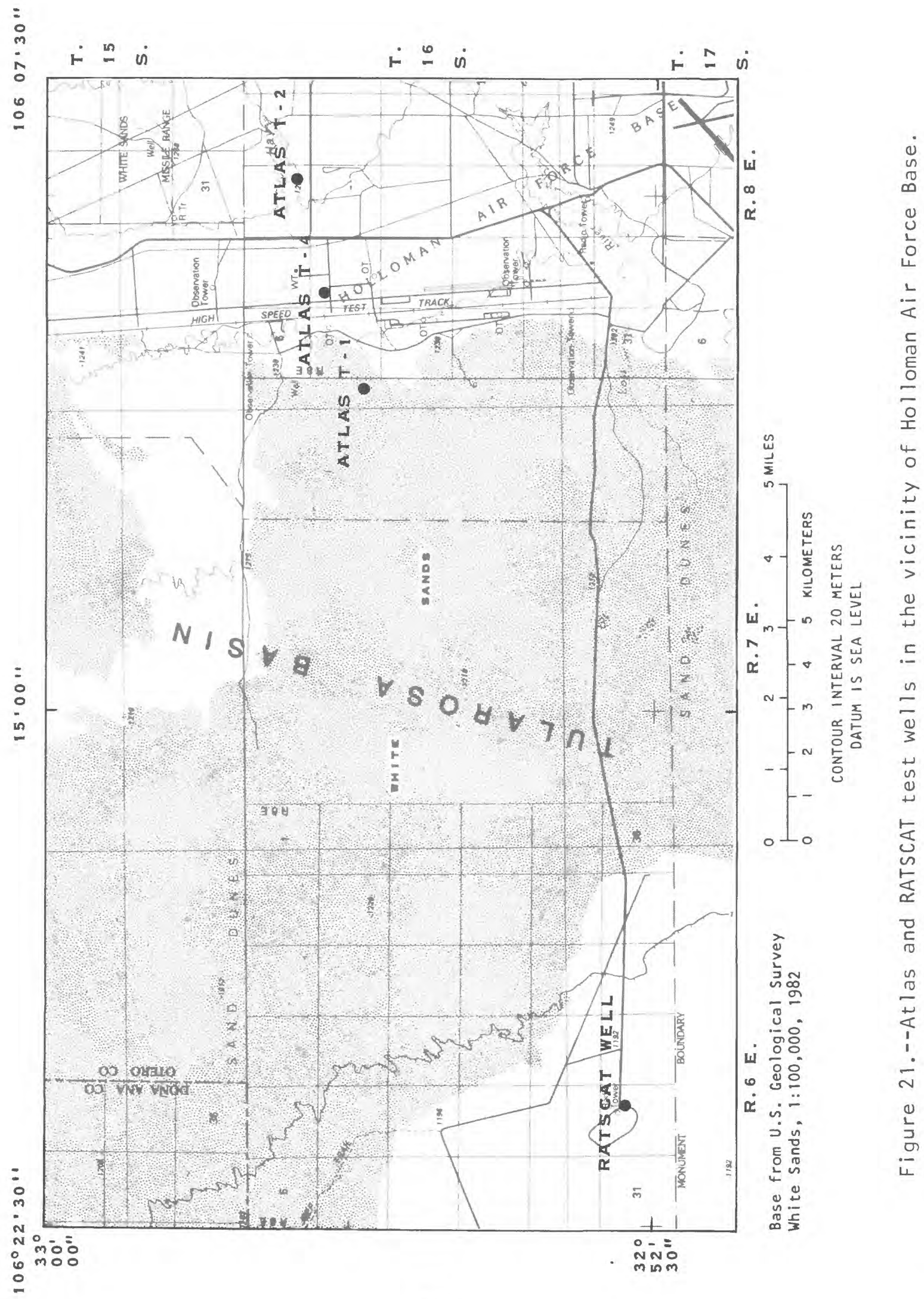


Specific-capacity estimates from the Atlas test wells are based on pumpage data obtained during well development. The wells were surged frequently during the tests and pumping rates varied. For this reason, hydraulic-conductivity estimates are only approximate. However, these estimates do indicate that water-bearing sand units within the clay probably do not readily transmit water.

\section{White Sands Missile Range}

Several test wells on White Sands Missile Range penetrated clay units that may be similar to lacustrine deposits throughout the basin. These wells include test well T-12 near the Post Headquarters area and several test wells in the vicinity of Rhodes Canyon.

\section{Test we11 $\mathrm{T}-12$}

White Sands Missile Range test well T-12 (22.4.23.444), drilled in 1967, is located within the White Sands reentrant (fig. 19) southwest of the Post Headquarters area. The well is east of and on the downthrown side of a northwest-trending fault that can be seen cutting $f$ an deposits in the reentrant. This well penetrated about 2,000 feet of basin-fill deposits and was completed to a depth of 1,820 feet (Cooper, 1970, p. 168). The production interval consists of 190 feet of mill-slotted casing installed at selected zones from 1,430 to 1,810 feet. According to geophysical logs (available only to a depth of 1,620 feet) permeable sand units may comprise 82 percent of the production interval. Although the well is located close to the basin margins, aquifer-test data indicated that hydrologic properties of the sand units in the production interval possibly are comparable to those of sand units in the lacustrine deposits farther into the basin.

An aquifer test was conducted on well T-12 in 1967 (Doty, 1968c, p. 21). From this test, the 8-hour specific capacity was 0.66 gallon per minute per foot of drawdown at a discharge of 30 gallons per minute. The transmissivity calculated from a Theis semilog plot of drawdown (Doty, 1968c, fig. 12) was 182 feet squared per day. Based on this transmissivity, the average hydraulic conductivity for the permeable sand units in the production interval is about 1.2 feet per day ( $t a b l e ~ 1)$. This small value of hydraulic conductivity indicates that water-bearing units in the production interval may consist of very fine grained sand or finer material (Lohman, 1972, p. 53). We11 T-12 is completed in the freshwater zone. Basinward, sand units with similar texture and saturated with very saline water may have smaller hydraulic-conductivity values because of increased fluid viscosity. 


\section{Rhodes Canyon test we11s}

Test well RC-3 (13.5.27.421) was drilled in 1969 to a depth of 750 feet (Lyford, 1970, p. 37). According to Lyford, four selected zones were tested to obtain water samples. Maximum yields from these tests ranged from 2 to 10 gallons per minute. According to geophysical logs of well RC-3, less than 3 percent of the saturated interval consists of very thin sand beds.

Aquifer-test data in other areas (Atlas wells, well $\mathrm{T}-12$ ) indicate that sand units within the lacustrine sediments are characterized by small values of hydraulic conductivity. Assuming an average hydraulic conductivity of about 1 foot per day, the estimated transmissivity of the water-bearing sediments penetrated by well $\mathrm{RC}-3$ may be less than 20 feet squared per day. If the lithology penetrated by this well is typical of the clay units beneath the gypsum deposits in the Lake Lucero area and beneath the fluvial and eolian deposits to the south, drawdown from pumpage in wells completed in these lacustrine deposits will be excessive and yields will be minimal.

Much of the basin-fill deposits probably consists of clay units similar to the thick lacustrine deposits penetrated at depth in stratigraphic test wel1 T-14. Thinly interbedded sand layers in these deposits may range from less than 3 percent of the total volume (well $\mathrm{RC}-3$ ) to as much as 26 percent (upper part of the lacustrine deposits penetrated by wel1 $\mathrm{T}-14$ ). Sand units may include thin clay interbeds as well as clay and silt in the sand matrix. The clay interbeds would reduce the overall hydraulic conductivity of the sand beds. If the hydraulic conductivity ranges from less than 1 foot per day to as much as 10 feet per day, the transmissivity for the upper 1,000 feet of lacustrine deposits may range from less than 30 feet squared per day to as much as 2,200 feet squared per day. Sand units are expected to respond to stress as a leaky-confined system. No well data are presently (1983) available that provide a quantitative determination of the capability of these sands to store and transmit water. If such data are required in the future, properly constructed test wells need to be drilled in representative areas of the Tularosa Basin and carefully designed multiple-well aquifer tests need to be conducted.

\section{Hydrologic Properties of the Central-Basin Gypsum-Playa Deposits}

Lake Lucero, the alkali flats to the north, and the gypsum dunes of White Sands National Monument are underlain by deposits of recrystallized gypsum. Allmendinger and Titus (1973) reported from 10 to 25 feet of crystallized gypsum deposits overlying lacustrine deposits in the vicinity of Lake Lucero. These gypsum deposits are saturated with highly mineralized water, and fluid levels generally are less than 10 feet below land surface. A test well known as the RATSCAT well (16.6.32.241), drilled in the alkali flats (fig. 21), penetrated 160 feet of these deposits before entering a clay unit. This well was completed in the gypsum deposits and was pumped at a rate 
of 35 gallons per minute for 2 hours with about 0.5 foot of drawdown. This test was of insufficient duration to provide quantitative information about the gypsum-playa deposits' capability to store and transmit water. However, it indicated that the gypsum deposits may be capable of moderate to 1 arge wel1 yields.

The gypsum-playa deposits probably are recharged by infiltration of surface runoff around the margins of the gypsum deposits. Herrick (1904, $p$. 187) reported the presence of karst sinkholes on the land surface east of the present dune field. These sinkholes may be the result of solutioning of gypsum and may provide an avenue for recharge of surface flow to the gypsumplaya deposits. It is doubtful that much upward ground-water movement occurs from the underlying lacustrine deposits because of their typically small permeability, but no hydrologic data are available to support this assumption.

Allmendinger and Titus (1973, fig. 10) collected water-level information from 51 auger holes around Lake Lucero in order to construct a water-level contour map. This contour map indicates that localized ground-water flow in the gypsum-playa deposits is toward Lake Lucero and that local discharge probably occurs at Lake Lucero through upward capillary movement and evaporation.

Limited hydrologic information about the gypsum-playa deposits precludes an accurate definition of the aquifer properties of these deposits. Additional test wells are needed to define more precisely the capability of the deposits to store and transmit fluid.

\section{Hydrologic Properties of the Deep Sand Unit (T-14)}

Geophysical logs from stratigraphic test well T-14 (22.5.15.221) indicate that more than 2,350 feet of permeable sand deposits underlie the thick lacustrine clay unit. No other deep-test data are available to indicate that these deposits are basinally extensive; however, the deposits may provide a deep source of very saline water which has sodium and chloride as the predominant ions and a dissolved-solids concentration as large as 52,800 milligrams per liter (Doty and Cooper, 1970, p. 28). Additional test wells in selected areas are needed to obtain information about the extent of this deep aquifer and its capability to store and transmit saline water. 


\section{ESTIMATION OF WATER IN STORAGE IN BASIN-FILL DEPOSITS}

A total volume of 4.2 billion acre-feet of saturated basin-fill deposits is estimated to be present in the Tularosa Basin. This estimate is derived from maps showing the altitudes of the water table and of the consolidated rock (Mclean, 1970, fig. 5). This volume includes alluvial-fan deposits saturated with freshwater on the east and west sides of the basin, a transitional zone of sediments saturated with slightly saline to very saline water, and the remaining basin-fill deposits, which comprise most of the basin and probably are saturated with brine containing concentrations of dissolved solids greater than 35,000 milligrams per liter.

\section{Fresh to Slightly Saline Water}

The total volume of freshwater in storage in the Tularosa Basin may be less than 4 percent of the combined volumes of freshwater, saline water, and brine. On the eastern side of the basin, in the area extending north from the Grapevine Canyon alluvial fan to a point 3 miles south of Alamogordo, the volume of deposits saturated with freshwater is estimated to be approximately 17.4 million acre-feet. Garza and McLean (1977, p. 38) calculated a specific yield of 8 percent in the vicinity of the Boles well field, based on the ratio of the volume of pumped water to the change in volume of saturated deposits caused by water-level declines resulting from pumping. McLean (1970, p. 20) estimated the specific yield in the San Andres well field to be 12 percent. Assuming a range of specific yield between 8 and 12 percent, about 1.4 to 2.1 million acre-feet of fresh ground water may be in storage, not all of which is recoverable.

On the west side in the New Mexico part of the Hueco Bolson, about 17.6 million acre-feet of sediments saturated with freshwater are estimated to be present in the area extending north from the New Mexico-Texas state line to a point south of the Soledad Canyon reentrant based on a freshwater saturatedthickness map (Knowles and Kennedy, 1958, p1. 11). About 29 mil1ion acre-feet of sediments saturated with freshwater are estimated to be present in the vicinity of the Soledad Canyon reentrant (Wilson and Myers, 1981, p. 12). An additional 22 million acre-feet of sediments saturated with freshwater are estimated to be present in the White Sands Missile Range Post Headquarters area based on a map by Kelly and Hearne (1976, fig. 5). About 3.0 million acre-feet of sediments saturated with freshwater are estimated to be present in the vicinity of the MAR Site well field based on geophysical and well data. The combined volume of sediments saturated with freshwater on the west side of the Tularosa Basin and the New Mexico part of the Hueco Bolson may be as much as 72 million acre-feet.

A specific yield of 15 percent was calculated by Herrick (1960a, p. 98) for freshwater-bearing deposits in the White Sands Missile Range post Headquarters area. Herrick made this estimate by dividing the volume of water pumped by the change in volume of saturated deposits that resulted from waterlevel declines caused by pumping. Assuming a specific yield of 15 percent, 10.7 million acre-feet of freshwater may be in storage on the west side from the State line to Ash Canyon, not all of which is recoverable. 
McLean (1970, p. 23) estimated that 360 million acre-feet of deposits saturated with slightly saline water may be present in the Tularosa Basin. Assuming a specific yield of 8 percent for these deposits, 29 million acrefeet of slightly saline water may be in storage in the basin, not all of which is recoverable.

\section{Hoderately Saline Water to Brine}

The volumes of moderately saline and very saline water may be of the same order of magnitude as the volume of slightly saline water (McLean, 1970, p. 23 and 26). If this assumption is true, the remainder of saturated sediments in the basin, approximately 3 billion acre-feet, may contain brine. Assuming that the specific yield of the fine-grained deposits of the central part of the basin is less than 6 percent (McLean, 1970, p. 17), less than 180 million acre-feet of brine may be in storage, again not all of which is recoverable. More than 85 percent of water in storage in the Tularosa Basin may contain dissolved-solids concentrations exceeding 3,000 milligrams per 1iter. 


\section{SUMMARY}

The distribution of fresh and slightly saline water in alluvial-fan deposits on the eastern side of the Tularosa Basin was described using 11 east-west geohydrologic sections constructed from surface-resistivity soundings and from available well data. Deposits in this area may range in thickness from about 100 feet to about 4,100 feet; the thickest deposits are in the vicinity of San Andres Canyon south of Alamogordo. South of Alamogordo, as much as 17.4 million acre-feet of sediments are saturated with freshwater (dissolved-solids concentration less than 1,000 milligrams per liter). Assuming the specific yield of freshwater-saturated sediments to be 8 to 12 percent, the amount of fresh ground water in storage on the east side of the basin could be from 1.4 to 2.1 million acre-feet, not all of which is recoverable. No appreciable amount of fresh ground water is present north of Al amogordo.

According to surface electrical-resistivity and water-chemistry data, an estimated 45 million acre-feet of deposits in the Alamogordo area may be saturated with slightly saline water (dissolved-solids concentrations from 1,000 to 3,000 milligrams per liter). Assuming a specific yield of 8 to 12 percent, 3.6 to 5.4 million acre-feet of slightly saline water may be in storage, not all of which is recoverable. In addition 14 to 21 million acrefeet of slightly saline water is estimated to be in storage north of Alamogordo. Additional data from deep wells are needed, particularly in the vicinity of the Grapevine Canyon alluvial fan, to determine more precisely the volumes of fresh and slightly saline water in storage.

Fresh and slightly saline ground water on the east side of the Tularosa Basin is characterized by a northward increase in dissolved solids. Predominant ions are calcium, sodium, magnesium, bicarbonate, and chloride.

On the western side of the Tularosa Basin, surface-resistivity soundings were made on alluvial-fan deposits associated with Rhodes Canyon and Ash Canyon. Five geohydrologic sections were constructed from these soundings and available well data.

Three geohydrologic sections for the Rhodes Canyon area indicate that the freshwater zone may range in thickness from about 1,500 feet near the fan apex to a feather edge eastward. Additional test wells are needed to verify the location and thickness of the fresh and slightly saline water zones.

Two geohydrologic sections for Ash Canyon and nearby drainages are located in the vicinity of test wells and supply wells of the MAR Site well field. The freshwater zone ranges in thickness from more than 600 feet near the mountain front to a feather edge eastward. About 3.0 million acre-feet of sediments in the vicinity of the MAR Site well field may be saturated with freshwater. Assuming an average specific yield of 15 percent, 450,000 acrefeet of freshwater may be in storage, not all of which is recoverable. 
Additional alluvial-fan deposits that could contain freshwater are between the Rhodes Canyon and Ash Canyon fans. Test wells and surfaceresistivity soundings are needed in these areas to estimate the extent and availability of these freshwater resources. The amount of freshwater in storage in alluvial fans on the west side of the Tularosa Basin and the New Mexico part of the Hueco Bolson may total 10.7 million acre-feet, not all of which is recoverable.

More than 85 percent of saturated deposits in the Tularosa Basin may contain saline ground water with concentrations of dissolved solids exceeding 3,000 milligrams per liter. In this study, five major hydrologic units that are known to contain saline water have been identified in the basin. These units are: (1) alluvial-fan deposits bordering the basin, (2) fluvial and eolian deposits mantling the south-central part of the basin, (3) extensive lacustrine deposits underlying the south-central alluvial deposits and also present in the shallow subsurface to the north, (4) gypsum-playa deposits in the central part of the basin, and (5) a thick unit of coarse-grained sediments that underlies the lacustrine deposits at depth. Because few wells have been drilled in areas of the Tularosa Basin where saline water is present, 1 ittle is known about the capability of basin-fill deposits to store and transmit saline water. Properly designed test wells are needed to more adequately evaluate the aquifer properties of these deposits.

Alluvial-fan deposits occur as thin pediments or veneers on underlying bedrock and basinward as thick units intertonguing with central-basin sediments. Fan deposits consist of laterally discontinuous, interbedded sand, gravel, silt, and clay. They are characterized by poorly sorted, coarsegrained deposits near the fan apex, and by predominantly fine-grained, we11sorted deposits at the distal part of the fan. The percentage of sand in saturated fan deposits ranges from about 12 to more than 95 percent.

The interbedded clay in alluvial-fan deposits probably restricts the vertical flow of water. In most areas, these deposits probably react to short-term stress as leaky-confined aquifers. Hydraulic-conductivity estimates for permeable units in the alluvial-fan deposits range from about 1.2 to 320 feet per day. Most of these tests were conducted in freshwater zones. Because the fluid viscosity increases with the concentration of dissolved solids and because hydraulic conductivity is inversely proportional to the viscosity, this range of hydraulic-conductivity values represents maximum values. Similar deposits saturated with brine would be characterized by smaller hydraulic-conductivity values. The storage coefficient for alluvial-fan deposits, which ranged in the short term from $1 \mathrm{X}$ $10^{-3}$ to $5 \times 10^{-3}$, is indicative of confined or artesian conditions and is probably related to the occurrence of interbedded clay units. Under long-term pumping stress, the storage coefficient probably will approach the specific yield of the water-bearing sediments, ranging from 8 to 15 percent. 
Extensive fluvial-eolian deposits of the south-central part of the Tularosa Basin may comprise a saline aquifer that may be more than 500 feet thick in places. These deposits may be correlated with deposits of the Hueco Bolson near El Paso, Texas. The few data that have been collected indicate that the average hydraulic conductivity may range from less than 18 to 60 feet per day. Under long-term pumping stress, the storage coefficient probably will approach the specific yield of the aquifer.

Lacustrine deposits as much as 3,440 feet thick underlie most of the Tularosa Basin. Very few wells have penetrated these deposits. Permeable sand units may comprise from 3 to 26 percent of the total thickness. The average hydraulic conductivity of these sand units may be about 1 foot per day; these sand units probably will react to pumping stress as leaky-confined aquifers.

Surficial gypsum-playa deposits predominantly consisting of recrystallized gypsum underlie Lake Lucero, White Sands National Monument, and the alkali flats to the north. These deposits may be as thick as 160 feet in places and are saturated to within a few feet of the land surface with highly mineralized water. Data from a limited number of wells indicate that this unit may be capable of producing moderate to large volumes of near-surface saline water.

A unit of coarse-grained sediments thicker than 2,350 feet in places and saturated with highly saline water may extensively underlie the lacustrine deposits of the Tularosa Basin. No data are available to describe the availability and extent of saline-water resources in this sand unit. 


\section{SELECTED REFERENCES}

Allmendinger, R. J., and Titus, F. B., Jr., 1973, Regional hydrology and evaporative discharge as a present-day source of gypsum at White Sands National Monument, New Mexico: New Mexico Bureau of Mines and Mineral Resources Open-File Report OF-55, 53 p.

Ballance, W. C., 1976, Ground-water resources of the Holloman Air Force Base well-field area, 1967; with a section on geophysical exploration by Robert Mattick: U.S. Geological Survey Open-File Report 76-807, 128 p.

Bjorklund, L. J., 1957, Reconnaissance of ground-water conditions in the Crow Flats area, Otero County, New Mexico: New Mexico State Engineer Technical Report 8, $19 \mathrm{p}$.

Brown, R. H., 1963, Estimating the transmissibility of an artesian aquifer from the specific capacity of a well, in Methods of determining permeability, transmissibility, and $\overrightarrow{\mathrm{raw}} \mathrm{d}$ own: U.S. Geological Survey Water-Supply Paper 1536-I, p. 336-338.

Bulloch, H. E., Jr., and Neher, R. E., 1980, Soil survey of Doña Ana County area, New Mexico: U.S. Department of Agriculture, 177 p.

Conover, C. S., Herrick, E. H., Hood, J. W., and Weir, J. E., Jr., 1955, The occurrence of ground water in south-central New Mexico, in Guidebook to south-central New Mexico: New Mexico Geological Society, 6th Field Conference, p. 108-120.

Cooper, J. B., 1958a, Ground water in the vicinity of Carrizozo, Lincoln County, New Mexico: U.S. Geological Survey open-file report, 32 p. 1958b, Ground-water conditions in the vicinity of Carrizozo, Lincoln County, New Mexico: U.S. Geological Survey open-file report, 45 p.

1965, Ground-water resources of the northern Tularosa Basin near Carrizozo, Lincoln County, New Mexico: U.S. Geological Survey HA-193, 1 sheet.

1970, Summary records of supply wells in the Post Headquarters area, White Sands Missile Range, New Mexico: U.S. Geological Survey open-file report, $202 \mathrm{p}$.

1973, Summary records of test and supply wells in range areas, White Sands Missile Range, New Mexico: U.S. Geological Survey open-file report, $132 \mathrm{p}$.

Cruz, R. C., 1972, Annual water-resources review, White Sands Missile Range, 1971--a basic-data report: U.S. Geological Survey open-file report, 35 p.

1973, Annual water-resources review, White Sands Missile Range, 1972--a basic-data report: U.S. Geological Survey open-file report, 35 p. 


\section{SELECTED REFERENCES - Continued}

Cruz, R. C., 1974, Annual water-resources review, White Sands Missile Range, 1973--a basic-data report: U.S. Geological Survey open-file report, 36 p.

1975, Annual water-resources review, White Sands Missile Range, 1974--a basic-data report: U.S. Geological Survey open-file report, 38 p.

1976, Annual water-resources review, White Sands Missile Range, 1975--a basic-data report: U.S. Geological Survey open-file report, 39 p.

1977, Annual water-resources review, White Sands Missile Range, 1976--a basic-data report: U.S. Geological Survey Open-File Report 77-330, 27 p.

1978, Annual water-resources review, White Sands Missile Range, 1977: U.S. Geological Survey Open-File Report 78-553, 31 p.

1979, Annual water-resources review, White Sands Missile Range, 1978: U.S. Geological Survey Open-File Report 79-985, 23 p.

1980, Annual water-resources review, White Sands Missile Range, 1979: U.S. Geological Survey Open-File Report 80-753, 25 p.

1981, Annual water-resources review, White Sands Missile Range, 1980: U.S. Geological Survey Open-File Report 81-921, 27 p.

1982, Annual water-resources review, White Sands Missile Range, 1981; U.S. Geological Survey Open-File Report $82-757,20$ p.

Dane, C. H., and Bachman, G. 0., 1965, Geologic map of New Mexico: U.S. Geological Survey, 2 sheets, scale 1:500,000.

Davis, L. V., and Busch, F. E., 1968, Summary of hydrologic investigations by the United States Geological Survey at White Sands Missile Range, New Mexico: U.S. Geological Survey open-file report, 299 p.

Derr, P. S., 1981, Soil survey of Otero area, New Mexico, parts of Otero, Eddy, and Chaves Counties: U.S. Department of Agriculture, 244 p.

Doty, G. C., 1968a, Summary of test wells drilled for MAR Site water supply, White Sands Missile Range, New Mexico: U.S. Geological Survey open-file report, $20 \mathrm{p}$.

1968b, Summary of production wells drilled for MAR Site water supply, White Sands Missile Range, New Mexico: U.S. Geological Survey open-file report, $19 \mathrm{p}$.

1968 c, Test wells in the Post Area, White Sands Missile Range, Doña Ana

County, New Mexico: U.S. Geological Survey open-file report, 50 p.

1968d, Phase I test wel1s, White Sands Missile Range, Doña Ana County, New Mexico: U.S. Geological Survey open-file report, 39 p. 


\section{SELECTED REFERENCES - Continued}

Doty, G. C., 1968e, Test wells drilled at Mockingbird Gap, Socorro County, New Mexico, June to October 1965: U.S. Geological Survey open-file report, 23 p.

1968f, Summary of wells drilled by White Sands Missile Range from June 1962 to January 1965: U.S. Geological Survey open-file report, 52 p.

Doty, G. C., and Cooper, J. B., 1970, Stratigraphic test we11 T-14, Post Area, White Sands Missile Range: U.S. Geological Survey open-file report, $34 \mathrm{p}$.

Dunham, K. C., 1935, The geology of the Organ Mountains: New Mexico Bureau of Mines Bulletin $11,272 \mathrm{p}$.

Gallegos, C. L., 1966, Water consumption statistics Holloman Air Force Base, New Mexico, 1943-1970: Unpublished report to Holloman Air Force Base.

Garza, Sergio, and McLean, J. S., 1977, Freshwater resources in the southeastern part of the Tularosa Basin: New Mexico State Engineer Technical Report 40,67 p.

Gates, J. S., and Stanley, W. D., 1976, Hydrologic interpretation of geophysical data from the southeastern Hueco Bolson, E1 Paso and Hudspeth Counties, Texas: U.S. Geological Survey Open-File Report 76-650, 37 p.

Gates, J. S., White, D. E., Stanley, W. D., and Ackerman, H. D., 1980, Availability of fresh and slightly saline ground water in the basins of westernmost Texas: Texas Department of Water Resources Report 256, 108 p.

Hawley, J. W., and Kottlowski, F. E., 1969, Quaternary geology of the southcentral New Mexico border region, in Border Stratigraphy Symposium: New Mexico Bureau of Mines and Mineral Resources Circular 104, p. 89-104.

Hawley, J. W., Kottlowski, F. E., Seager, W. R., King, W. E., Strain, W. S., and LeMone, D. V., 1969, The Santa Fe Group in the south-central New Mexico border region, in Border Stratigraphy Symposium: New Mexico Bureau of Mines and Mineral Resources Circular 104, p. 52-76.

Hendrickson, G. E., 1949, Ground-water resources of the Carrizozo area, New Mexico: U.S. Geological Survey open-file report, $14 \mathrm{p}$.

Herrick, C. L., 1904, Lake Otero, an ancient salt lake in southeastern New Mexico: American Geologist, v. 34, p. 174-189.

Herrick, E. H., 1960a, Ground-water resources of the headquarters (cantonment) area, White Sands Proving Ground, Doña Ana County, New Mexico: U.S. Geological Survey open-file report, 203 p.

1960b, Reconnaissance of ground-water conditions southeast of Valmont, Otero County, New Mexico: U.S. Geological Survey open-file report, 5 p. 


\section{SELECTED REFERENCES - Continued}

Herrick, E. H., and Davis, L. V., 1965, Availability of ground water in the Tularosa Basin and adjoining areas, New Mexico and Texas: U.S. Geological Survey HA-191, 2 p.

Herrick, E. H., and others, 1960, Appraisal of ground-water resources of Tularosa Basin and adjoining areas, New Mexico and Texas: U.S. Geological Survey open-file report, $195 \mathrm{p}$.

Hood, J. W., 1956a, Ground water in the vicinity of McGregor Range camp site, Otero County, New Mexico: U.S. Geological Survey open-file report, 76 p.

1956b, Summary of results of ground-water investigations in the vicinity of Boles well field, Otero County, New Mexico: U.S. Geological Survey open-file report, $17 \mathrm{p}$.

1958, Ground-water resources and related geology in the vicinity of Holloman Air Force Base, Otero County, New Mexico: U.S. Geological Survey open-file report, $261 \mathrm{p}$.

1959, Ground water in the Tularosa Basin, New Mexico, in Sacramento Mountains of Otero County, New Mexico: Guidebook for Joint Field Conference, Permian Basin Section, Society of Economic Paleontologists and Mineralogists and Roswell Geological Society, p. 236-250.

1960, Ground water in the vicinity of the Atlas site, Holloman Air Force Base, Otero County, New Mexico: U.S. Geological Survey open-file report, $38 \mathrm{p}$.

1968, Ground-water investigations at White Sands Missile Range, New Mexico, July 1960-June 1962: U.S. Geological Survey open-file report, $157 \mathrm{p}$.

Hood, J. W., and Herrick, W. H., 1962, Water resources of the Three Rivers area, Otero and Lincoln Counties, New Mexico: U.S. Geological Survey open-file report, $3 \mathrm{p}$.

1965, Water resources of the Three Rivers area, Otero and Lincoln Counties, New Mexico: U.S. Geological Survey HA-192, 1 sheet.

Hood, J. W., and Kister, L. R., 1960, Saline-water resources of New Mexico: U.S. Geological Survey Water-Supply Paper 1601, $67 \mathrm{p}$.

Johnson, R. B., and Read, C. B., eds., 1952, Rio Grande country, central New Mexico: New Mexico Geological Society Guidebook, 3rd Field Conference.

Kel1y, T. E., 1973, Summary of ground-water data, Post Headquarters and adjacent areas, White Sands Missile Range: U.S. Geological Survey OpenFile Report 72-308, 66 p. 


\section{SELECTED REFERENCES - Continued}

Kelly, T. E., and Hearne, G. A., 1976, The effects of ground-water development on the water supply in the Post Headquarters area, White Sands Missile

Range: U.S. Geological Survey Open-File Report 76-277, 97 p.

Kelly, T. E., Myers, B. N., and Hershey, L. A., 1970, Saline ground-water resources of the Rio Grande drainage basin--a pilot study: U.S. Department of the Interior, office of Saline Water Research and Development Progress Report 560, 71 p.

King, W. E., Hawley, J. W., Taylor, A. M., and Wilson, R. P., 1969, Hydrogeology of the Rio Grande valley and adjacent intermontane areas of southern New Mexico: Water Resources Research Institute Report 6, $141 \mathrm{p}$.

Knowles, D. B., and Kennedy, R. A., 1958, Ground-water resources of the Hueco Bolson northeast of El Paso, Texas: U.S. Geological Survey Water-Supply Paper 1426,186 p.

Kottlowski, F. E., 1960, Summary of Pennsylvanian sections in southwestern New Mexico and southeastern Arizona: New Mexico Bureau of Mines and Mineral Resources Bulletin 66, $187 \mathrm{p}$.

Kottlowski, F. E., Flower, R. H., Thompson, M. L., and Foster, R. W., 1956, Stratigraphic studies of the San Andres Mountains, New Mexico: New Mexico Bureau of Mines and Mineral Resources Memoir 1, 132 p.

Krieger, R. A., Hatchett, J. L., and Poole, J. L., 1957, Preliminary survey of the saline-water resources of the United States: U.S. Geological Survey Water-Supply Paper 1374, $172 \mathrm{p}$.

Laudon, L. R., and Bowsher, A. L., 1941, Mississippian formations of Sacramento Mountains, New Mexico: American Association of Petroleum Geologists Bulletin, v. 25, no. 12, p. 2114-2116.

1949, Mississippian formations of southwestern New Mexico: Geological Society of America Bulletin, v. 60, no. 1, p. 17-19.

Lohman, S. W., 1972, Ground-water hydraulics: U.S. Geological Survey Professional Paper 708,70 p.

Lyford, F. P., 1970, Test wel1s T-15, T-16, T-17, T-18, and RC-3, White Sands Missile Range, Doña Ana and Sierra Counties, New Mexico: U.S. Geological Survey open-file report, $46 \mathrm{p}$.

McLean, J. S., 1970, Saline ground-water resources of the Tularosa Basin, New Mexico: U.S. Department of the Interior, office of Saline Water Research and Development Progress Report 561, $128 \mathrm{p}$.

Meeks, T. 0., 1950, The occurrence of ground water in the Alamogordo-Tularosa area of the Otero Soil Conservation District, New Mexico: Soil

Conservation Service, Regional Bulletin $111,42 \mathrm{p}$. 


\section{SELECTED REFERENCES - Continued}

Meinzer, O. E., and Hare, R. F., 1915, Geology and water resources of Tularosa Basin, New Mexico: U.S. Geological Survey Water-Supply Paper 343, 317 p.

Meyer, W. R., 1976, Digital model for simulated effects of ground-water pumping in the Hueco Bolson, E1 Paso area, Texas, New Mexico, and Mexico: U.S. Geological Survey Water-Resources Investigations 75-58, $106 \mathrm{p}:$

Neher, R. E., and Bailey, O. F., 1976, Soil survey of White Sands Missile Range, New Mexico, parts of Otero, Lincoln, Doña Ana, Sierra, and Socorro Counties: U.S. Department of Agriculture, $64 \mathrm{p}$.

$$
\text { Ens. }
$$

Nelson, L. A., 1940, Paleozoic stratigraphy of the Franklin Mountains of west Texas: American Association of Petroleum Geologists Bulletin, v. 24, p. $157-172$.

Otte, Care1, Jr., 1959, Late Pennsylvanian and Early Permian stratigraphy of the northern Sacramento Mountains, Otero County, New Mexico: State Bureau of Mines and Mineral Resources Bulletin 50, $111 \mathrm{p}$.

Pray, Li.C., 1954, Outline of the stratigraphy and structure of the Sacramento Mountain escarpment, in Guidebook to southeastern New Mexico: New Mexico Geological Society, 5th Field Conference, p. 92-107.

1961 , Geology of the Sacramento Mountains escarpment, Otero County, New Mexico: New Mexico Bureau of Mines and Mineral Resources Bulletin 35, $114 \mathrm{p}$.

Rapp, J.R.; 1958, Summary of test drilling and ground-water conditions in the McGregor Range area, Otero and Doña Ana Counties, New Mexico and El Paso County, Texas: U.S. Geological Survey open-file report, 83 p. sti

Roswell Geological Society Stratigraphic Problems Committee, 1956, West-east correlation section, San Andres Mountains to New Mexico-Texas line, southeastern New Mexico, 1 p.

Ruhe, R. V., 1967, Geomorphic surfaces and surficial deposits in southern New Mexico:-. New Mexico Bureau of Mines and Mineral Resources Memoir 18, 65 p. $5, \cdots$

Sandeen, W. M., 1954, Geology of the Tularosa Basin, southeastern New Mexico, in Guidebook to southeastern New Mexico: New Mexico Geological Society, 5th Fieild Conference, p. 81-88.

A

Sayre, A. N., and Livingston, Penn, 1945, Ground-water resources of E1 Paso area, Texas: U.S. Geological Survey Water-Supply Paper 919, 190 p. …

Schmidt,-P.:G.; and Craddock, Campbe11, 1964, The geology of the Jarilla Mountains, Otero County, New Mexico: New Mexico Bureau of Mines and Mineralkesources Bulletin $82,55 \mathrm{p}$. 


\section{SELECTED REFERENCES - Concluded}

Smith, C. T., and Budding, A. J., 1959, Reconnaissance geologic map of Little Black Peak fifteen-minute quadrangle, east half: New Mexico Bureau of Mines and Mineral Resources Geological Map 11, 1 sheet.

Strain, W. S., 1965, Early Pleistocene history of southern part of Mesilla Bolson [abs.], in Guidebook to southwestern New Mexico II: New Mexico Geological Society, 16th Field Conference, p. 243.

1966, Blancan mammalian fauna and Pleistocene formations, Hudspeth County, Texas: Austin, Texas, Texas Memorial Museum Bulletin 10 .

1968, Cenozoic rock in the Mesilla and Hueco Bolsons, in Guidebook to Delaware Basin exploration: West Texas Geological. Society, p. 83-84.

1969, Late Cenozoic strata of the El Paso area, in Border Stratigraphy Symposium: New Mexico Bureau of Mines and Mineral Resources Circular 104, p. $122-123$.

Theis, C. V., 1963, Estimating the transmissibility of a water-table aquifer from the specific capacity of a well, in Methods of determining permeability, transmissibility, and drawdown: U.S. Geological Survey Water-Supply Paper 1536-I, p. 332-336.

Weir, J. E., Jr., 1965, Geology and availability of ground water in the northern part of the White Sands Missile Range and vicinity, New Mexico: U.S. Geological Survey Water-Supply Paper 1801, 78 p., 11 figs.

Weist, R. C., ed., 1983, CRC Handbook of Chemistry and Physics, 63rd ed.: CRC Press, Inc.

White, D. E., Hem, J. D., and Waring, G. W., 1963, Chemical composition of subsurface waters: U.S. Geological Survey Professional Paper 440-F, p. 67 .

Wilson, C. A., and Myers, R. G., 1981, Ground-water resources of the Soledad Canyon re-entrant and adjacent areas, White Sands Missile Range and Fort Bliss Military Reservation, Doña Ana County, New Mexico: U.S. Geological Survey Water-Resources Investigations Report 81-645, $22 \mathrm{p}$.

Wilson, C. A., White, R. R., Roybal, R. G., and Gonzales, J. L., 1978, Drilling, construction, and testing of water-supply wells 21 and 22 , White Sands Missile Range, Doña Ana County, New Mexico: U.S. Geological Survey Open-File Report 78-172, 34 p.

Winslow, A. G., and Kister, L. R., 1956, Saline-water resources of Texas: U.S. Geological Survey Water-Supply Paper 1365, 105 p.

Zohdy, A. A. R., Jackson, D. B., Mattick, R. E., and Peterson, D. L., 1969, Geophysical survey for ground water at White Sands Missile Range, New Mexico: U.S. Geological Survey open-file report, 144 p. 
Table 1.--Wel1-record information, transmissivity estimates, and hydraulic-conductivity estimates of water-bearing zones in basin-fill deposits, Tularosa Basin

\begin{tabular}{|c|c|c|c|c|c|c|}
\hline $\begin{array}{l}\text { We } 11 \\
\text { name }\end{array}$ & $\begin{array}{l}\text { Location } \\
\text { number }\end{array}$ & $\begin{array}{l}\text { Transmis- } \\
\text { sivity ( } \mathrm{T}) \\
\text { (feet squared } \\
\text { per day) }\end{array}$ & $\begin{array}{l}\text { Production } \\
\text { interval } \\
\text { (feet) }\end{array}$ & $\begin{array}{l}\text { Total } \\
\text { thick- } \\
\text { ness } \\
\text { (feet) }\end{array}$ & $\begin{array}{l}\text { Per- } \\
\text { cent } \\
\text { s and }\end{array}$ & $\begin{array}{c}\text { Hydraulic } \\
\text { conductivity } \\
(\mathrm{K}) \\
\text { (feet per day) }\end{array}$ \\
\hline At 1 as $\mathrm{T}-1$ & $16 \cdot 8 \cdot 13.400$ & $60 e$ & -- & (40 feet & of $s$ and) & 1.5 \\
\hline At 1 as $\mathrm{T}-2$ & $16 \cdot 9 \cdot 4 \cdot 400$ & $380 \mathrm{e}$ & $74-412$ & 338 & 26 & $4 \cdot 3$ \\
\hline At 1 as $\mathrm{T}-4$ & $16 \cdot 9 \cdot 8 \cdot 100$ & $160 \mathrm{e}$ & -- & 258 & 28 & 2.2 \\
\hline $\mathrm{NW}-30$ & 17.4 .2 .211 & 1,100 & $260-654$ & 122 & 57 & 16 \\
\hline S.A. 3 & $17 \cdot 10 \cdot 31 \cdot 424$ & 1,160 & $180-942$ & 762 & 40 & 3.8 \\
\hline S.A. 4 & $17 \cdot 10 \cdot 32 \cdot 234$ & 20,000 & -- & -- & -- & 23非 \\
\hline MAR-4 & 19.5 .19 .231 & 39,440 & $436-740$ & 130 & 95 & 320 \\
\hline MAR SW-1 & 19.5 .17 .331 & $840-1,340$ & $230-550$ & 320 & 12 & 35 \\
\hline MAR SW-2 & $19 \cdot 5 \cdot 17 \cdot 334$ & $600-1,036$ & $227-650$ & 423 & 12 & 21 \\
\hline SMR-3 & $20 \cdot 5 \cdot 34.133$ & 46,900 & $330-990$ & 200 & 85 & 276 \\
\hline SMR-1 & $21 \cdot 5 \cdot 16 \cdot 132$ & 1,053 & $286-473$ & 128 & 49 & 17 \\
\hline SMR-2 & $21 \cdot 5 \cdot 17.424$ & 2,670 & $295-715$ & 400 & 17 & 39 \\
\hline SMR-4 & $21 \cdot 5 \cdot 20 \cdot 344$ & 13,400 & $470-570$ & 100 & -- & 134 非 \\
\hline $\mathrm{T}-13$ & $21 \cdot 5 \cdot 32.222$ & 804 & $285-702$ & 110 & 91 & 8.0 \\
\hline $\mathrm{T}-8$ & 22.4 .11 .224 & 160 & $574-1040$ & 160 & $?$ & 1.0 非 \\
\hline SW-20 & $22 \cdot 4 \cdot 12 \cdot 214$ & 79,000 & $462-838$ & 376 & -- & 210 非 \\
\hline SW-19 & $22 \cdot 4 \cdot 12.414$ & 10,700 & $400-800$ & 400 & 45 & 59 \\
\hline SW-18 & 22.4 .12 .434 & 632 & $400-800$ & 400 & 24 & 6.6 \\
\hline SW-17 & 22.4 .13 .241 & 4,020 & $436-886$ & 300 & -- & 13 非 \\
\hline SW-13 & 22.4 .13 .311 & 670 & $373-534$ & 84 & -- & 8.0 非 \\
\hline SW-14 & 22.4 .13 .411 & 1,070 & $370-810$ & 250 & 48 & 8.9 \\
\hline SW-15 & $22 \cdot 4 \cdot 13 \cdot 424$ & 3,790 & $350-820$ & 270 & 55 & 25 \\
\hline SW-16 & 22.4 .13 .432 & 4,420 & $370-886$ & 340 & 68 & 19 \\
\hline SW-12 & 22.4 .23 .214 & 670 & $330-560$ & 145 & -- & 4.6 非 \\
\hline $\mathrm{T}-12$ & $22 \cdot 4 \cdot 23.444$ & 182 & $1430-1810$ & 190 & $82 *$ & 1.2 \\
\hline SW-11 & 22.4 .24 .112 & 335 & $380-490$ & 110 & 64 & 4.8 \\
\hline $\mathrm{SW}-10$ & 22.4 .24 .212 & 8,170 & $264-494$ & 230 & - & 36非 \\
\hline $\mathrm{SW}-10 \mathrm{~A}$ & $22.4 .24 .212 a$ & 15,300 & $405-805$ & 400 & 32 & 120 \\
\hline Main Gate & $22.4 \cdot 24.222$ & 2,360 & $388-438$ & 50 & -- & 47非 \\
\hline$T-10$ & $22 \cdot 5 \cdot 3 \cdot 313$ & 1,862 & $370-545$ & 85 & 89 & 24 \\
\hline
\end{tabular}


Table 1.--We11-record information, transmissivity estimates, and hydraulic-conducțivity estimates of water-bearing zones in basin-fill deposits, Tularosa Basin - Concluded

\begin{tabular}{|c|c|c|c|c|c|c|}
\hline $\begin{array}{l}\text { Well } \\
\text { name }\end{array}$ & $\begin{array}{c}\text { Location } \\
\text { number }\end{array}$ & $\begin{array}{c}\text { Transmis- } \\
\text { sivity ( T) } \\
\text { (feet squared } \\
\text { per day) }\end{array}$ & $\begin{array}{l}\text { Production } \\
\text { interval } \\
\text { (feet) }\end{array}$ & $\begin{array}{l}\text { Total } \\
\text { thick- } \\
\text { ness } \\
\text { (feet) }\end{array}$ & $\begin{array}{l}\text { Per- } \\
\text { cent } \\
\text { s and }\end{array}$ & $\begin{array}{c}\text { Hydraulic } \\
\text { conductivity } \\
(\mathrm{K}) \\
\text { ( feet per day) }\end{array}$ \\
\hline $\mathrm{T}-7$ & $22 \cdot 5 \cdot 7 \cdot 342$ & 2,134 & $326-966$ & 200 & 16 & 52 \\
\hline SW-22 & $22 \cdot 5 \cdot 19.414$ & 4,560 & $459-725$ & 276 & 12 & 84 \\
\hline SW-21 & $22 \cdot 5 \cdot 19 \cdot 323$ & 1,660 & $455-690$ & 235 & 14 & 48 \\
\hline $\mathrm{T}-11$ & $22 \cdot 5 \cdot 29.412$ & 1,698 & $306-760$ & 206 & 60 & 14 \\
\hline Gregg SW & $22 \cdot 6 \cdot 8 \cdot 414 a$ & 2,620 & $265-465$ & 145 & -- & 18非 \\
\hline$T-16$ & $23 \cdot 5 \cdot 10 \cdot 413$ & 4,790 & $310-700$ & 100 & 96 & 50 \\
\hline $\mathrm{T}-17$ & $23 \cdot 5 \cdot 27 \cdot 142$ & 2,380 & $440-544$ & 66 & 61 & 60 \\
\hline
\end{tabular}

Values of $\mathrm{K}$ calculated only for sand units within production interval, except values denoted by 非, which represents $\mathrm{K}$ from the entire production interval. $(*)$ denotes percent sand from the upper part of the production interval only. (e) indicates $T$ estimated from specific-capacity data. 
Table 2.--Estimates of transmissivity calculated from specificcapacity data from wells in the Tularosa Basin

[Technique used to estimate transmissivity described in Brown (1963, p. 336-338) and Theis (1963, p. 332-336)]

\begin{tabular}{|c|c|c|c|c|c|c|}
\hline \multirow[b]{2}{*}{$\begin{array}{l}\text { Well } \\
\text { name }\end{array}$} & \multirow[b]{2}{*}{$\begin{array}{c}\text { Location } \\
\text { number }\end{array}$} & \multirow{2}{*}{$\begin{array}{c}\text { Specific } \\
\text { capacity } \\
\text { (gallons per } \\
\text { minute } \\
\text { per foot) }\end{array}$} & \multirow[b]{2}{*}{$\begin{array}{l}\text { Test } \\
\text { duration } \\
\text { (hours) }\end{array}$} & \multirow{2}{*}{$\begin{array}{l}\text { Assumed } \\
\text { effective } \\
\text { radius } \\
\text { (inches) }\end{array}$} & \multicolumn{2}{|c|}{$\begin{array}{c}\text { Estimated } \\
\text { transmissivity } \\
\text { (feet squared per day }\end{array}$} \\
\hline & & & & & $\begin{array}{l}\text { From } \\
\text { specific } \\
\text { capacity }\end{array}$ & $\begin{array}{l}\text { From } \\
\text { aquifer } \\
\text { test }\end{array}$ \\
\hline & & [Storage & coefficie & of $10^{-3}$ ] & & \\
\hline $\mathrm{NW}-30$ & 17.4 .2 .211 & 8.0 & 8 & $8-10$ & 1,740 & 1,100 \\
\hline S.A. 3 & $17 \cdot 10 \cdot 32 \cdot 424$ & 4.0 & 9 & $16-24$ & 1,070 & 1,160 \\
\hline MAR SW-1 & 19.5 .17 .331 & 3.1 & 24 & $10-20$ & 670 & $840-1,340$ \\
\hline MAR SW-2 & $19 \cdot 5 \cdot 17.334$ & .83 & 24 & $10-20$ & 220 & $600-1,036$ \\
\hline MAR-4 & 19.5 .19 .231 & 55 & 8 & $8-12$ & 14,040 & 39,440 \\
\hline SMR-3 & $20 \cdot 5 \cdot 34 \cdot 133$ & 97 & 8 & $8-12$ & 25,700 & 46,900 \\
\hline SMR-1 & $21 \cdot 5 \cdot 16 \cdot 132$ & 4.5 & 12 & $6-9$ & 1,070 & 1,053 \\
\hline SMR-2 & 21.5 .17 .424 & 13 & 3.5 & $6-8$ & 2,940 & 2,670 \\
\hline SMR-4 & $21 \cdot 5 \cdot 20 \cdot 344$ & 29 & 8 & $8-12$ & 7,220 & 13,400 \\
\hline $\mathrm{T}-13$ & $21 \cdot 5 \cdot 32 \cdot 222$ & 3.2 & 8 & $8-11$ & 670 & 804 \\
\hline $\mathrm{T}-8$ & $22.4 \cdot 11.224$ & 2.0 & 8 & $8-10$ & 400 & 160 \\
\hline SW-20 & 22.4 .12 .214 & 131 & 8 & $16-36$ & 34,000 & 79,000 \\
\hline SW-19 & 22.4 .12 .414 & 53 & 8 & $16-36$ & 12,400 & 10,700 \\
\hline SW-18 & 22.4 .12 .434 & 10 & 8 & $16-36$ & 2,140 & 632 \\
\hline SW-17 & $22 \cdot 4 \cdot 13.241$ & 26 & 12 & $14-28$ & 6,150 & 4,020 \\
\hline SW-13 & $22 \cdot 4 \cdot 13 \cdot 311$ & 3.6 & 5 & $12-24$ & 670 & 670 \\
\hline SW-14 & 22.4 .13 .411 & 7.8 & 48 & $12-26$ & 1,740 & 1,070 \\
\hline$S W-15$ & 22.4 .13 .424 & 21 & 40 & $12-26$ & 5,350 & 3,790 \\
\hline SW-1 6 & 22.4 .13 .432 & 24 & 48 & $12-26$ & 6,150 & 4,420 \\
\hline $\mathrm{sW}-12$ & 22.4 .23 .214 & 3.2 & 42 & $12-?$ & 800 & 670 \\
\hline $\mathrm{T}-12$ & $22.4 \cdot 23.444$ & 0.66 & 8 & $6-8$ & 175 & 182 \\
\hline$S W-11$ & $22 \cdot 4 \cdot 24 \cdot 112$ & 8.4 & 4 & $12-24$ & 1,670 & 335 \\
\hline$S W-10$ & $22.4 \cdot 24.212$ & 24 & 72 & $12-24$ & 6,280 & 8,170 \\
\hline$S W-10 A$ & $22.4 .24 .212 a$ & 95 & 10.5 & $16-36$ & 23,300 & 15,300 \\
\hline$T-10$ & $22 \cdot 5 \cdot 3 \cdot 313$ & 6.9 & 8 & $8-12$ & 1,600 & 1,862 \\
\hline $\mathrm{T}-7$ & $22 \cdot 5 \cdot 7 \cdot 342$ & 12 & 8 & $8-12$ & 2,670 & 2,134 \\
\hline$S W-22$ & $22 \cdot 5 \cdot 19 \cdot 414$ & 20 & 8 & $16-30$ & 4,340 & 4,560 \\
\hline
\end{tabular}




\begin{tabular}{|c|c|c|c|c|c|c|}
\hline \multirow[b]{2}{*}{$\begin{array}{l}\text { We } 11 \\
\text { name }\end{array}$} & \multirow[b]{2}{*}{$\begin{array}{l}\text { Location } \\
\text { number }\end{array}$} & \multirow[b]{2}{*}{$\begin{array}{c}\text { Specific } \\
\text { capacity } \\
\text { (gallons per } \\
\text { minute } \\
\text { per foot) }\end{array}$} & \multirow[b]{2}{*}{$\begin{array}{c}\text { Test } \\
\text { duration } \\
\text { (hours) }\end{array}$} & \multirow[b]{2}{*}{$\begin{array}{l}\text { Assumed } \\
\text { effective } \\
\text { radius } \\
\text { (inches) }\end{array}$} & \multicolumn{2}{|c|}{$\begin{array}{c}\text { Estimated } \\
\text { transmissivity }\end{array}$} \\
\hline & & & & & $\begin{array}{c}\text { From } \\
\text { specific } \\
\text { capacity }\end{array}$ & $\begin{array}{l}\text { From } \\
\text { aquifer } \\
\text { test }\end{array}$ \\
\hline \multicolumn{7}{|c|}{ [Storage } \\
\hline $\begin{array}{l}\text { SW-21 } \\
\text { T-11 } \\
\text { Gregg T } \\
\text { T-16 } \\
T-17\end{array}$ & $\begin{array}{l}22 \cdot 5 \cdot 19 \cdot 323 \\
22 \cdot 5 \cdot 29 \cdot 412 \\
22 \cdot 6 \cdot 8 \cdot 414 \\
23 \cdot 5 \cdot 10 \cdot 413 \\
23 \cdot 5 \cdot 27 \cdot 142\end{array}$ & $\begin{array}{l}14 \\
6.2 \\
14 \\
11 \\
5.7\end{array}$ & $\begin{array}{r}10 \\
8 \\
8 \\
8 \\
8\end{array}$ & $\begin{array}{r}16-30 \\
8-10 \\
13-18 \\
8-18 \\
8-18\end{array}$ & $\begin{array}{l}3,000 \\
1,470 \\
3,000 \\
2,540 \\
1,340\end{array}$ & $\begin{array}{l}1,660 \\
1,698 \\
2,620 * \\
4,790 \\
2,380\end{array}$ \\
\hline \multicolumn{7}{|c|}{ [Storage coefficient of 0.15 ] } \\
\hline $\mathrm{NW}-30$ & 17.4 .2 .211 & 8.0 & 8 & $8-10$ & 1,140 & 1,100 \\
\hline $\mathrm{T}-8$ & 22.4 .11 .224 & 2.0 & 8 & $8-10$ & 270 & 160 \\
\hline SW-18 & $22.4 \cdot 12.434$ & 10 & 8 & $16-36$ & 1,200 & 632 \\
\hline SW-17 & 22.4 .13 .241 & 26 & 12 & $14-28$ & 3,740 & 4,020 \\
\hline SW-14 & 22.4 .13 .411 & 7.8 & 48 & $12-26$ & 1,270 & 1,070 \\
\hline SW-15 & 22.4 .13 .424 & 22 & 40 & $12-26$ & 3,600 & 3,790 \\
\hline SW-16 & 22.4 .13 .432 & 24 & 48 & $12-26$ & 4,010 & 4,420 \\
\hline SW-11 & 22.4 .24 .112 & 8.4 & 4 & $12-24$ & 1,070 & 335 \\
\hline SW-10A & $22.4 \cdot 24.212 a$ & 95 & $10 \cdot 5$ & $16-36$ & 15,400 & 15,300 \\
\hline$S W-21$ & 22.5 .19 .323 & 14 & 10 & $16-30$ & 1,540 & 1,600 \\
\hline
\end{tabular}

(*) denotes transmissivity determined in test of adjacent well. 